\title{
Analysis of Reactor Trips Originating in Balance of Plant Systems
}

Manuscript Completed: May 1990

Date Published: September 1990

Prepared by

F. T. Stetson, D. W. Gallagher, P. T. Le, M. W. Ebert

Science Applications International Corporation

Post Office Box 1303

1710 Goodridge Drive

McLean, VA 22102

Prepared for

Division of Systems Technology

Office of Nuclear Reactor Regulation

U.S. Nuclear Regulatory Commission

Washington, DC 20555

NRC FIN D1313 


\section{ABSTRACT}

This report documents the results of an analysis of balance-of-plant (BOP) related reactor trips at commercial U.S. nuclear power plants over a 5-year period, from January 1, 1984, through December 31, 1988. The study was performed for the Plant Systems Branch, Office of Nuclear Reactor Regulation, U.S. Nuclear Regulatory Commission. The objectives of the study were:

1. to improve the level of understanding of BOP-related challenges to safety systems by identifying and categorizing such events;

2. to prepare a computerized data base of BOP-related reactor trip events and use the data base to identify trends and patterns in the population of these events;

3. to investigate the risk implications of BOP events that challenge safety systems;

4. to provide recommendations on how to address BOP-related concerns in a regulatory context. 
Executive Summary $\ldots \ldots \ldots \ldots \ldots \ldots \ldots \ldots \ldots \ldots \ldots \ldots \ldots \ldots \ldots \ldots$

1. INTRODUCTION. ............................ $1-1$

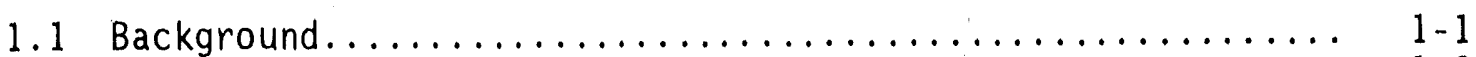

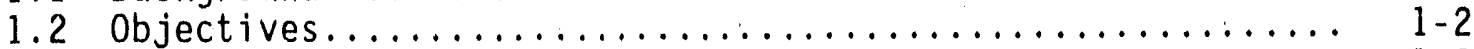

1.3 Scope of the Study................................. $1-2$

1.4 Organization of the Report..................... 1-4

References.............................. 1-5

2. BOP DATA BASE DEVELOPMENT ...................... 2 - 1

3. TREND AND PATTERN EVALUATIONS USING THE BOP DATA BASE........ $3-1$

3.1 BOP Trips per Calendar Year......................... $3-1$

3.2 BOP Trips per Critical Year--Annual.................. $3-4$

3.3 BOP Trips per Critical Year - Cumulative Average......... 3-6

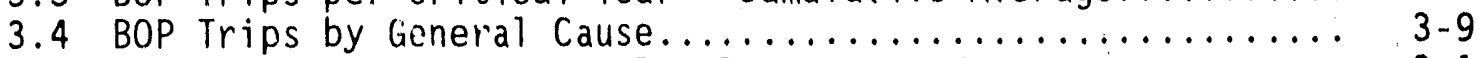

3.5 BOP Trips by Sincle or Multiple Causes.............. 3-10

3.6 BOP Trips by system and Subsystem................. 3-12

3.7 BOP Trips by System and Component.................. 3-12

3.8 BOP Trip Frequency and Feedwater System Design Characteristics................................ 3-12

3.9 BOP Trips by Plant, NSSS Vendor and A/E............ 3-17

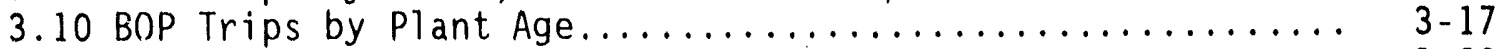

3.11 BOP Trips as a Function of Power Leve1.............. 3-20

3.12 Origin of the Reduction in BOP Trips............... 3-20

References............................. 3-27

4. INSIGHTS ON BOP EVENTS ....................... 4 -1

4.1 General Observations........................ 4-1

4.2 Specific Trends and Patterns....................... 4-2

References.............................. 4-11

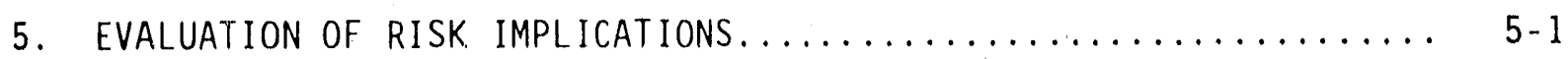

5.1 Impact of BOP System Performance on Plant Core Melt Frequency............................. 5-2

5.2 BOP Influence on Accident Precursor Events............ 5-15

5.3 Summary of Risk Implications..................... 5-23 
6. FINDINGS AND RECOMMENDATIONS ..................... $6-1$

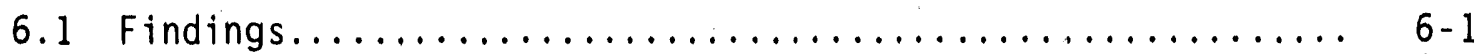

6.2 Recommendations............................ $6-5$

APPENDIX A: Sample Entries from the BOP Data Base............. A-1

APPENDIX B: BOP Trips per Calendar Year by Plant (Raw Data, 1984-

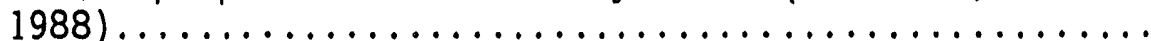

APPENDIX C: BOP Trips per Critical Year by Plant (Normalized Data,

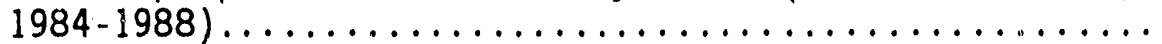

APPENDIX D: BOP Trips per Critical Year by Plant (Cumulative Average,

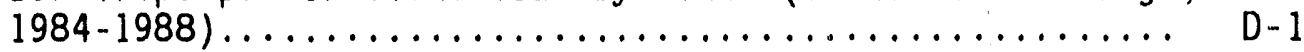

APPENDIX E: BOP Trips by Systems and Subsystems............. E-1

APPENDIX F: BOP Trips by Systems and Components............. F-1

APPENDIX G: Mature Plants' Feedwater Pumping Capacity............ G-1

APPENDIX $H:$ BOP Trips by Plant with NSSS Vendor and A/E........ H-1

APPENDIX I: BOP Trips as a Function of Power Leve $1 \ldots \ldots \ldots \ldots \ldots \ldots$ I-I

APPENDIX J: Supplemental Data Base Plant Design Data........... J-1

APPENDIX K: Supplemental Data Base Critical Hour Data............ K-1

APPENDIX L: Sources of Information....................... 


\section{Figure}

Page

2-1: BOP Data Base Format........................ 2-3

3-1: Age-Dependence of BOP-Related Trips................. 3-19

Table Page

2-1: 47 Sequence Coding and Search System (SCSS) Codes.......... 2-2

3-1: BOP Data Base Search Logic.................... 3-2

$\begin{aligned} 3-2: & \text { Average BOP Trips per Uni per Calendar Year } \\ & (1984 \text { through 1988) } \ldots \ldots \ldots \ldots \ldots \ldots \ldots \ldots \ldots \ldots \ldots \ldots \ldots \ldots \ldots \ldots \ldots \ldots\end{aligned}$

3-3: Average BOP Trips per Unit per Critical Year
1984 through $1988 \ldots \ldots \ldots \ldots \ldots \ldots \ldots \ldots \ldots \ldots \ldots \ldots \ldots \ldots \ldots \ldots \ldots \ldots$

3-4: Range of BOP Performance (BOP Trips, $1984-1988$ ).......... 3-7

3-5: BOP Trips per Critical Year per Unit, 5-year Cumulative

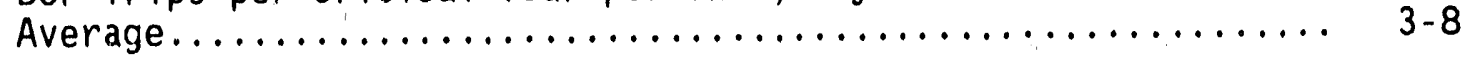

3-6: BOP Trips by Cause (A11 units 1984-1988).............. 3-9

3-7: Single- and Multiple-Cause BOP Trips (A11 units 1984-1988).... 3-11

3-8: BOP Trips by System and Subsystem (A11 units $1984-1988$ )..... 3-13

3-9: BOP Trips by System and Component (A11 units 1984-1988)..... 3-14

3-10: BOP Trips by NSSS Vendor and A/E Firm (All units 1984-1988)... 3-18

3-11: BOP Trips by Power Level (A11 units 1984-1988)........... 3-21

3-12: BOP Trips by General Cause by Year.................. 3-22

3-13: Feedwater Trips by Year by Vendor (A11 units) ............ 3-23

3-14: Turbine Trips by Year by Vendor (A11 units) ............. 3-25

3-15: Type of Human-Related Cause by Year (Al1 plants, 1984-1988)... 3-26

4-1: Comparison of Estimates of Initiating System Contributors to

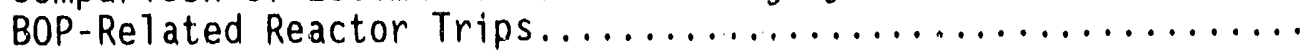




\section{LIST OF ILLUSTRATIONS (Continued)}

Table

Page

5-1: BOP Induced Transients Based on 1984-1987 LER Data.......... 5-5

5-2: Average Frequency of BOP-Induced Transients Based on 1984-1987

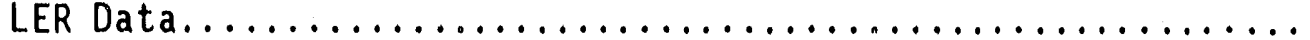

5-3: Comparison of PRA Transient Initiator Frequencies to BOP-Related Transient Initiator Frequencies Based on 1984-1987 LER Data (events/yr) ................................. 5-8

5-4: Contributions to Core Melt Frequencies at Connecticut Yankee Due to Changes in BOP-Related Transient Initiator Frequencies.

5-5: Summary of Calculated Core Melt Frequency Results (CMF (/yr)... 5-11

5-6: Contribution of BOP-Related Transients to Core Melt Frequency.. 5-14

5-7: Summary 1984 Precursor Report Data Events with Conditional

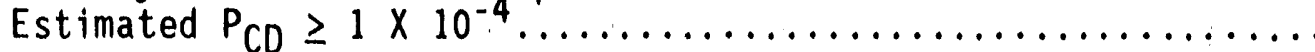

5-8: Summary 1985 Precursor Report Data Events with Conditional

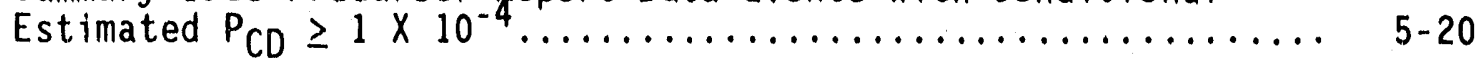

5-9: Summary 1986 Precinsor Report Data Events with Conditional

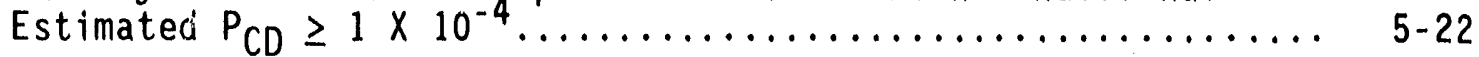

5-10: Summary of BOP Influence on Precursor Events, 1984-1986..... 5-24 
This report documents the results of a characterization and subsequent analys is of balance-of-plant (BOP)-related reactor trips at commercial U.S. nuclear power $\mathrm{plants}$ over the 5-year period from January 1, 1984 through December 31, 1988. The study was performed for the P1ant Systems Branch, office of Nuclear Reactor Regulation, U.S. Nuclear Regulatory Commission.

\section{Objectives}

The objectives of the study were to:

1. improve the level of understanding of BOP-related challenges to safety systems by identifying and categorizing such events;

2. prepare a computerized data base of BOP-related reactor trip events and use the data base to identify trends and patterns in these events;

3. investigate the risk implications of BOP events that challenge safety systems; and

4. provide recommendations on how to address BOP-related concerris in a regulatory context.

\section{Sources of BOP Information}

The primary sources of information used in the study were:

o an earlier investigation of BOP events reported in NUREG/CR-4783, BOP Regulatory Issues, January 1987;

- Licerisee Event Reports (LERs) accessed through the Sequence coding and Search System (SCSS) maintained for USNRC by Oak Ridge National Laboratory; and 
a study by the NRC Office for Analysis and Evaluation of Operational Data (AEOD), NUREG-1275 Volume 5, Operating Experience Feedback Report - Progress in Scram Reduction, March 1989.

Additional sources of information were industry organizations (e.g., INPO, Owners Groups), NRC documents (e.g., NUREG and NUREG/CR reports, AEOD reports, inspection reports, generic letters, notices and bulletins) and information on foreign scram reduction programs, e.g., Proceedings of a Nuclear Energy Agency Symposium on Reducing the Frequency of Nuclear Reactor Scrams, Tokyo, Japan, 1986.

\section{BOP Data Base Development}

As part of this study, a computerized data base of BOP-related reactor trips was created, based on information provided in Licensee Event Reports (LERs) over the period January 1, 1984, through December 31, 1988. The Sequence Coding and Search system (SCSS) for the LER data base was used to identify potentially relevant LERs. The LER search on 47 BOP-related SCSS codes produced 2030 LERs with some level of BOP involvement.

The 2030 LER printouts were examined individually against predetermined criteria for BOP relevance, and 1405 events were considered appropriate for entry into a BOP trip data base. LERs were not included in the BOP trip data base if any of the following conditions applied:

o BOP involvement was incidental to the reactor trip, i.e., not in the causation sequence.

- The trip occurred during special tests or evolutions during shutdown conditions and would not have occurred when the reactor was critical or at power. Events occurring at shutdown conditions that could have occurred at power or with substantial decay heat in the core were included in the BOP trip data base.

0 The trip resulted from loss of offsite power or other events external to the plant systems. 
The BOP trip data base was developed on PC-dBase III Plus software. Each event record identifies the BOP system (e.g., feedwater), subsystem (e.g., feedwater control), and component (e.g., feedwater control valve) as applicable. Up to three potential causes of the event may be specified. A narrative event description is also provided.

Supplementary data bases were al so found to be necessary for conducting analyses of trends and patterns. The supplementary data bases contain plant data and critical hours data. The supplementary plant data base includes the following data elements:

- Operating 1 icense (OL) date

- Nuclear Steam Supply System (NSSS) vendor

- Architect/engineer

o Turbine/generator manufacturer.

The critical hours supplementary data base inciudes:

- Critical hours per year for each plant of the years 1984 through 1988

- Total critical years accumulated during the period 1984 through 1988.

\section{Trend and Pattern Evaluations}

The 5-year, 1405-event BOP trip data base was searched for trends and patterns in the data. Searches were performed on BOP trips per plant per calendar year; BOP trips per plant per critical year; general causation of BOP trips (i.e., component fallure, human-related, design-related, etc.); multiple cause BOP trips; systems, subsystems, and components implicated in BOP trip causation; and trend observations by architect/engineer, plant age and plant power level at trip. Several special searches (e.g., feedwaicr trips by NSSS vendor by year) were also performed to help understand the results of earlier searches.

A basic distinction was made between mature plants and new plants. Mature plants were defined as those which received operating licenses (OLs) before 
January 1, 1933. Thus, all plants in the mature plant category had held an $O L$ for at least one year before the start of the LER period covered by the study-January 1, 1984. This definition of mature plants resulted in a constant population of 76 plants for trend and vattern analysis. A "floating" definition of mature plants (e.g., 1 or 2 years after the $\mathrm{OL}$ date) was considered but not adopted because it would have introduced another variable (plant population) into the trend and pattern analysis.

BOP Trips per Calendar Year

The mature nuclear plants showed a substantial reduction in BOP trips over the 5-year perlod, from an average of 2.8 BOP trips per calendar year in 1984 to 1.6 BOP trips per calendar year in 1988.

BOP Trips per Critical Year

The mature nuclear plants showed a substantial reduction in BOP trips nver the 5-year period, from an average of 4.4 BOP trips per critical year in 1984 to an average of 2.3 BOP trips per critical year in 1988.

General Causation of BOP Trips

The general causation categories used in the study were component failure, human-related, design-related, procedure-related, and spurious or unknown. Nearly half ( 47 percent) of the BOP trips were caused by one or more component fallures, and nearly one-third (31 percent) were human-related. The human-related BOP trips were further categorized by the activity in progress as follows: 40 percent operations, 40 percent maintenance, 14 percent surveillance, 6 percent other.

Multiple-Cause BOP Trips

Approximately 70 percent of the BOP trips were determined to be single-cause events. However, a substantial fraction (27 percent) would not have occurred in the absence of a second condition, and a few trips ( 3 percent) would not have occurred in the absence of two additional conditions. 


\section{Causation of BOP Trips--Systems Implicated}

The two largest system contributors to BOP trips were the feedwater system, causing 40 percent of the trips, and the turbine/generator system, contributing about 30 percent. The next largest contributors, the $A C$ power and main steam systems, contributed about 12 percent and 6.5 percent, respectively. Other systems, contributing 3 percent or less to BOP trips over the study period, include air, circulating water, DC power, and instrumentation and control systems.

Causation of BOP Trips--Subsystems Implicated

Feedwater control was the dominant contributing subsystem to feedwaterrelated BOP trips. Within the turbine/generator system, the dominant contributing subsystem was instrumentation and control, primarily the electro-hydraulic control (EHC) subsystem. Feedwater control and T/G I\&C subsystem problems (component fallure or human-related) combined caused about 40 percent of the total BOP trips.

\section{Causation of BOP Trips--Components Implicated}

The clearly dominant "component" contributor to BOP trips was the human, generally causing about 30 percent of all BOP trips across the major system contributors. The next largest component contributors, generally much less significant than the human, were pumps, valves, electrical switchgear, and circuit cards. For the dominant systems, the data are characterized by a majority of the trips coming from very small contributions from very large numbers of components.

Trends in BOP Trips as a Function of Architect/Engineer

The BOP data base was searched to see if positive or negative performance in terms of BOP trips could be correlated with the architect/engineer $(A / E)$ responsible for designing the BOP. For the major $A / E$ firms that have designed several nuclear units-Bechtel, Stone \& Webster, Sargent \& Lundy and Ebasco--no clear trends were evident in the data as a function of the $A / E$ firm that designed the BOP. 
The data on BDP trips as a function of plant age were widely scattered; even the annual average values at a given age showed a large degree of variability. The overall trend, determined by a linear least squares fit of the annual average data, showed a reduction of about one BOP trip (during the 5 years considered in the study) for every 2 years of increasing age.

Trends in BOP Trips as a Function of Power Level

Approximately half of the BOP trips observed over the study period occurred above 75 percent power, and those trips were dominated by problems in the turbine/generator system. Nearly 30 percent of the observed trips occurred below 25 percent power, and they were dominated by problems in the feedwater system. The remaining trips were distributed evenly between the 25 percent to 50 percent range and the 50 percent to 75 percent range in power level.

BOP Trips vs. Feedwater System Design Characteristics

Because of the predominance of trips initiated by feedwater system problems, an analysis was done to determine if feedwater system design characteristics were associated with differences in BOP trip frequency. Three aspects of feedwater system design were analyzed: the number of feedwater pumps, feedwater supply capacity per pump, and the type of pumps (motor-driven versus turbine-driven).

The data indicates that plants with three feedwater pumps perform only marginally better than plants with two feedwater pumps in terms of both feedwater trips and overall BOP trips. This parameter does not appear to be significant in terms of BOP trip performance. Similarly, plants with excess feedwater capacity (e.g., 100 percent capacity with one pump out of service) performed only marginally better than plants without excess capacity in terms of both feedwater trips and overall BOP trips.

The on? significant trend observed during these feedwater system evaluations was that amost all of the best performers have motor-driven feed pumps and that almost all of the worst performers have turbine-driven feed pumps. All of the top nine performers in overall BOp trips (that is, fewest 
trips per critical year) had motor-driven feed pumps, while five of six of the worst performers had turbine-driven feed pumps. If feedwater-systeminduced reactor trips are considered instead of BOP trips, six of the worst seven have turbine-driven feed pumps and eight of the nine best have motordriven feed pumps. Similarly, if only feedwater-control-induced reactor trips are considered, six of the seven worst performers have turbine-driven pumps, while four of the top seven have motor-driver feed pumps.

\section{Risk Implications of BOP Events}

The objective of this task was to evaluate the impact of BOP-related events on the risk, as measured by estimated core malt frequency, of nuclear power plant operation. The task was divided into two paris. First, a quantitative analysis was performed to estimate the risk impact of reactor trips caused by BOP system failures. Second, a qualitative evaluation was performed of the impact of BOP-related events on safety system availability, as reflected by the events having a relatively high risk ranking as reported in the Accident Sequence Precursor program for the years 1984 through 1986.

The results of the delt' 1 risk analysis and the evaluation of BOP-related precursor events both show that the reliability of BOP system can have a siyilificant impact on the risk profile of nuclear power plants. For BWRs, in particular, plant core melt frequency appears to be highly sensitive to the frequency of BOP-related transients. The delta risk analysis showed that core melt frequency differed by a factor of 2 to 4 as a function of BOP performance for BWRs. The difference for PWRs was comparatively small, only a factor of 1.1 to 1.3 .

For the years 1984 through 1986, 35 precursor events were identified that had estimated conditional probabilities of severe core damage greater than or equal to $1 \times \mathrm{iO}^{-4}$. Twenty-three of these 35 events (66 percent) had BOP initiators. Thus, the fraction of BOP initiation of the more significant precursor events is approximately the same as the fraction of BOP initiation of reactor trips in general.

Twelve of the 23 precursor events that were considered to be BOP-related and had a high probability of resulting in core damage occurred at BWRs. This 
is a disproportionate number of such events as BWRs, since approximately two-tinirds of all operating U.S. reactors are PWRs. This finding supports the conclusion that BOP-related events are more important, from a risk perspective, at BWRs.

\section{Findings and Recommendations}

The major finding of this stuady was the dramatic reduction in BOP-related trips at commercial nucl power plants over the 5-year study period from January 1, 1984 through December 31, 1988. This improved performance reduces the urgency of regulatory action to address BOP-related safety concerns. However, regulatory actions can be taken to (1) address the problems of licensees whose BOP trips performance is substantially less favorable than the industry average, and (2) maintain or further improve the performance levels achieved toward the end of the study period.

\section{Findings}

1. For the 76 mature nuclear units (OL before January 1, 1983) in the study data base, the average number of BOP trips per unit was reduced from 4.4 per critical year in 1984 to 2.4 per critical year in 1988.

2. On a calendar year basis, for the 76 mature nuclear units in the study data base, the average number of BOP trips per unit was reduced from 2.8 per calendar year in 1984 to 1.6 per calendar year in 1988.

3. Nearly 30 percent of the BOP-related trips resulted from multiple-cause events.

4. Approximately 70 percent of the $B O P$-related trips resulted from a single event.

5. Considering BOP trips resulting from both single and multiple causes, nearly four out of every five events contributing to BOP trips were either component/equipment failures (47 percent) or human actions ( 31 percent). 
6. NSSS Owners Groups with aggressive trip reduction programs are apparently achieving results in the form of reduced frequencies of BOPrelated trips.

7. At the system level, BOP trip causation was dominated by the condensate/feedwater system (40 percent of total trips) and the turbine/generator system (30 percent of total trips).

8. At the subsystem leve1, BOP trips causation was dominated by the feedwater control subsystem (61 percent of feedwater-related trips; 25 percent of total trips) and the turbine/generator instrumentation and control subsystem (60 percent of turbine/generator related trips; 18 percent of total trips).

9. At the component level, excluding the human "component," BOP trip causation was not dominated by any single component or small group of components.

10. Nearly all the units with the best BOP trip performarice (fewest BOPrelated trips) have motor-driven feedwater pumps; nearly all the units with the poorest BOP trip performance (highest numbers of BOP trips) have turbine-driven feedwater pumps.

11. From a risk perspective, BOP-related transients contribute significantly more, on a fractional basis, to the estimated core melt frequencies of BWRs than thej do to PWRs.

12. BOP-related transients are the initiating events for approximately twothirds of the more significant accident precursor events.

\section{Recommendations}

The dramatic reduction in the number of BOP-related reactor trips at commercial nuclear power plants over the 5-year period ending December 31 , 1988 reduces the urgency of regulatory actions directed at BOP performance improvements. However, regulatory actions can and should be taken to (1) maintain the trend toward decreasing numbers of BOP-related reactor trips 
among NRC licensees, and (2) address the problems of licensees whose performance is substantially less favorable than the industry average.

\section{General Recommendations}

1. Communicate to licensees and applicants, in the form of an informational generic letter, the results of recent studies on BOPrelated trips and overall scram reduction experience.

2. Identify, monitor and communicate with licensees who are not achieving an acceptably low frequency of BOP-related trip events at their facilities.

3. NRC should work with INPO, the Owners Groups, and EPRI to assist licensees in achieving and maintaining an acceptably low frequency of BOP-related trip events at their nuclear plants.

4. NRC should formally incorporate BOP trip avoidance experience into the Systematic Assessment of Licensee Performance (SALP) process, e.g., as an element in the Safety Assessment/Quality Verification category.

\section{Specific Recommendations}

1. Establish a responsibility center within NRC to specifically monitor and evaluate BOP-related reactor trip experience.

2. NRC should expand the role of BOP systems in ongoing NRC activities, specifically in the areas of inspections, maintenance policy, Technical Specifications improvements, human factors and training, severe accident policy/IPEs, the Accident Sequence Precursor program, and advanced reactors/standardization.

3. NRC should expand the evaluation of the risk implications of BOP events to additional PRA studies to test the validity of the risk-related findings made herein.

4. NRC should investigate the implications of the relatively large numbers of multiple-cause events for statistical and risk analyses. 


\section{INTRODUCTION}

This report documents a study of reactor trips related to balance-of-plant (BOP) system failures at commercial U.S. nuclear power plants. The study was performed to support assessment of the safety implications of BOPrelated trips and to contribute to identification of ways to achieve and maintain low occurrence frequencies for such trips. The study was performed by Science Applications International Corporation for the U.S. Nuclear Regulatory Commission, Office of Nuclear Reictor Regulation, Plant Systems Branch.

\subsection{Background}

For the past several years, the NRC staff has been concerned with the nonsafety-related balance-of-plant (BOP) systems and the effects that failures in the BOP systems have on the safety of the plant. For the purposes of this study, the BOP is considered to consist of what is often referred to as the secondary system (a11 systems associated with the steam power conversion cycle) and supporting systems, such as instrument air and cooling water. The basic concern is the frequency of challenges to plant safety systems that come about as a result of failures in the BOP systems. Because the BOP systems are often designed without any redundancy, there can be any number of single active failures in the BOP systems that can result in a reactor plant trip, usually because of a turbine trip or a loss of main feedwater. Such challenges to the safety systems could be considered a weakness in the defense-in-depth philosophy that has always been the cornerstone of nuclear power plant regulation.

A previous analysis of BOP regulatory issues by Mitre Corporation, (NUREG/CR-4783, Reference 1) found that during 1984 and 1985 BOP-related trips constituted about 70 percent of the total reactor trips. It can be argued that BOP designs that incorporate redundancy are able more often to accommodate plant transients and equipment failures without requiring a reactor trip and a subsequent challenge to safety systems. Similarly, plant maintenance practices and techniques, plant operating characteristics, and even plant aging can increase the challenges to safety systems. A careful study of the operational data and experiences, combined with the use of quantitative risk assessment techniques, was needed to enable the NRC to 
better understand the sources of challenges to safety systems and to estimate the effect on public risk of BOP-related trips.

\subsection{Objecuives}

The overall objectives of this study were to perform a comprehensive review and evaluation of BOP-related challenges to safety systems, to examine the risk implications of these events, and to make recommendations for resolving BOP-related concerns. The study examined the initiators of BOP challenges, the frequency of these initiators, the degree of design sensitivity or tolerance to these initiators through design features such as redundancy, and the effects on public risk of excessive BOP challenges to safety systems. Specific objectives were to identify generic BOP-related problems, common cause events, similarities and effectiveness of utility/industry programs, and effectiveness of NRC-related activities and to evaluate them with emphasis on developing an overall approach to the resolution of BOP. related concerns.

\subsection{Scope of the Study}

The initial task was to identify and evaluate available information concerning BOP-related events and activities. Sources of information included (1) BOP-related studies by NRC and NRC contractors, (2) evaluations performed as a result of NRC requirements or requests, (3) generic issues and unresolved safety issues, (4) documentation of operating events (e.g., Licensee Event Reports), (5) information from the activities of the Advisory Committee on Reactor Safeguards (ACRS), (6) information generated by the NRC Office for Analysis and Evaluation of Operational Data (AEOD), and (7) efforts performed by utflities and industry groups (e.g., owners groups). These sources of information are discussed in more detail in Appendix $L$.

Licensee Event Reports (LERs) were obtained for evaluation through the use of the Sequence Coding and Search System (SCSS) data base of LERs maintained for the NRC by Oak Ridge National Laboratory. For the purposes of this study, a reactor trip was defined as an actuation of the reactor protection system, automatic or manual, independent of whether or not actual control rod motion occurred. 


\subsubsection{Defintition of BOP}

One of the early tasks in the scope of the study was to define balance-ofplant systems. Definitions of BOP are numerous, and are a function of the context in which the term is used. For the purposes of this study, it was decided to devise an operational (as opposed to theoretical) definition of BOP in terms of the system codes used in the SCSS. The "definition" of BOP used in the study incompasses 47 SCSS codes and related titiles provided later in Table 2-1. This resulted in a comprehensive 1ist of BOP systems, including all portions of the power conversion system, $A C$ and $D C$ power, instrumentation, several air and water systems, and others.

\subsubsection{Mitre Report}

The Mitre report on BOP regulatory issues, mentioned in Section 1.1 above, was used as a point of departure for this study. Four major differences between this study and that reported in the Mitre report are: (1) the definition of BOP used herein included about three times as many BOP systems, not just those associated with power conversions (2) the LER data base evaluated herein covered a period of 5 years, 1984 through 1988, instead of 2 years; (3) this study examined the risk implications of BOP performance; and (4) one task in this study was the preparation of a BOP. specific reactor trip data base, to facilitats the identification of trends and patterns in the population of BOP-related events.

\subsubsection{AEOD Report}

This study of BOP-related reactor trips was performed in parallel with a portion of a broader-scoped NRC AEOD study that examined progress being made by 1 icensees in reducing the frequencies of reactor trips from all causes. The study performed by AEOD was reported in NUREG-1275, Volume 5 (Reference 2). The BOP study differs from the AEOD study in that it:

o looks exclusively at BOP-related trip events;

$0 \quad$ includes the preparation of a BOP-related reactor trip data base to identify the relative contributions of component failures 
(single and multiple), design adequacies, human errors (operation, maintenance, test), and procedural inadequactes;

- includes the performance of detafled trend and pattern analyses of the BOP data base on many parameters, inc?uding plant, year, age, NSSS vendor, A/E, turbine manufacturer, general cause, system, subsystem, and component implicated; and

- includes calculations of the estimated incremental risks associated with BOP fallures.

\subsection{Organization of the Report}

The development and use of the BOP data base are described below in Sections 2 and 3 , respectively. Insights gained from searching the BOP data base are summarized in Section 4. The reslitss of a brief overview of the risk implications of BOP systems failures are presented in Section 5, including an estimate of the incremental risk associated with favorable versus unfavorable BOP performance, based on selected probabilistic risk assessment studies and on information concerning BOP influence on accident precursor events. Section 6 presents the findings and recommendations of the study. Detailed data are provided in Appendices $A-L$. 


\section{References}

1. NUREC/CR-4783, "Analys is of Balance of P1ant Regulatory Issues," Mitre Corporation, January 1987.

2. NUREG-1275, Vo1. 5, "Operating Experience Feed'rack Report - Progress in Scram Reduction, Commerctal Power Reacturs, "USNRC, Office for Analysis and Evaluation of Uperational Data, March 198'9. 


\section{BOP DATA BASE DEVELOPMENT}

A data base of BOP-related reactor trips was created as part of this study. BOP trip data were drawn from the Licensee Event Report (LER) data base ma!ntained by Oak Ridge National Laboratory (ORNL). The Sequence Coding and Search System (SCSS) for the LER data base was used to identify potentially relevant LERs. Table 2-1 1ists the 47 SC,SS codes, and the corresponding BOP systems, used in the LER search. The LER search on the 47 SCSS codes covered the 5-year perlod from January 1, 1984, through December 31, 1988. Approximately 2030 trips involving BOP systems were identified.

The information collected from the LER search was analyzed to determine whether the reactor trip was directly related to a fallure of a BOP component or function. If so, the trip information was incorporated into the BOP data base.

Of the 2030 LERs reviawed, 1405 BOP-related events were considered appropriate for entry into the BOP data base. LERs were not included in the BOP data base if any of the following conditions applied:

- BOP involvement was incidental to the trip, f.e., not in the causation sequence.

- The trip occurred during spectal tests or evolutions during shutdown conditions and would not have occurred when the reactor was critical or at power. Accidents occurring at shutdown conditions that could conceivably have occurred at power, or with substantial decay heat in the core were included in the BOP data base.

0 The trip resulted from loss of offsite power or other events external to the plant systems.

The BOP data base was developed based on PC-dBase III Plus software. The varlous data elements or "fields" are presented in Figure 2-1, which also shows the format used for entering applicable data into the data base. 
Table $2-1$

47 Sequence Coding and Search System (SCSS) codes

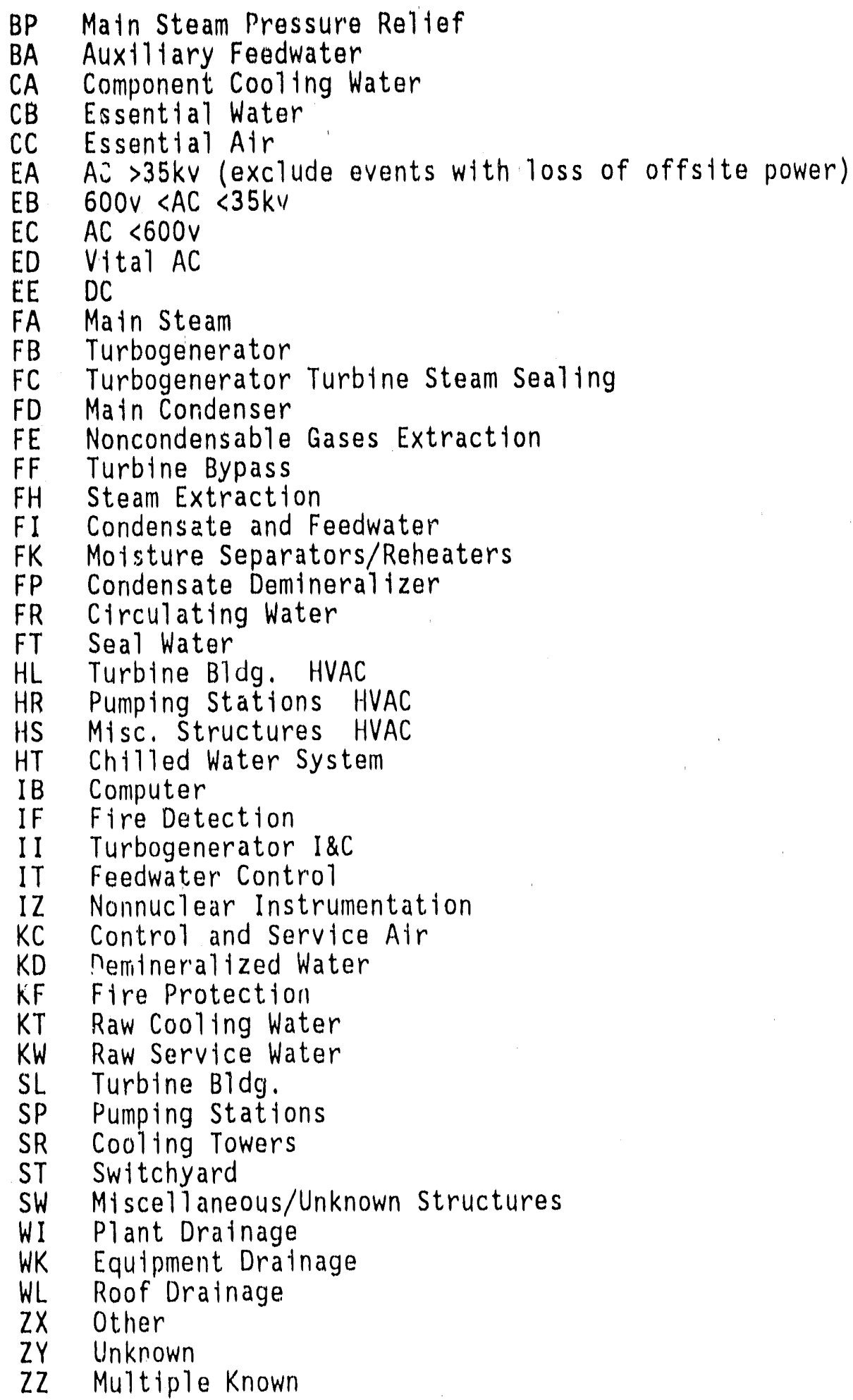




\section{BOP Data Base Format}

Plant: Plant-Name

Form: $\quad 1-4$ digtt identifying number

Event ID: LER ID number Power Level: $0-100 \%$

Event Date: MM/DD/YY Trip Type: Automatic/Manual

BOP System: System name (up to 30 characters)

BOP Subsystem: Subsystem name (up to 30 characters).

BOP Component: Component type (up to 40 characters)

Cause 1: Root causes of event: Component

Cause 2: Fallures, human errors, etc.

Cause 3: (up to 40 characters each)

Impact 1: Events, other than plant trips, resulting from BOP

Impact 2: event, e.g., safety system fallures (up to 40 characters edich)

Impact 3:

Event Description: Text description of event

Figure 2-1. BOP Data Base Format 
The "Form" entry in Figure 2-1 is an LER-spectfic identification number for locating the LER from which the data was taken. The event record identifies the BOP system (e.g., feedwater), subsystem (e.g., feedwater control), and component (e.g., feedwater control valve) as applicable. Up to three potential causes of the event may be spectfled. A narrative event description is also provided. Appendix A contains a sample of 30 entries from the BOP data base.

Supplementary data bases were also found to be necessary for conducting analyses of trends and patterns. The supplementary data bases contain plant data and critfcal hours (number of hours the reactor was critical) data. The supplementary plant data base includes the following data elements:

- Operating 1 icense (OL.) date
$0 \quad$ Nuclear Stuam Supply System (NSSS) vendor
$0 \quad$ Architect/engineer
$0 \quad$ Turbine-generator manufacturer.

The critfcal hours supplementary data base includes:

- Critical hours per y'ear for each plant for the years 1984 through 1988

- Total critical years accumulated during the pertod 1984 through 1988.

Printouts of these supplementary data bases are included in Appendices $\mathrm{J}$ and $K$. 


\section{TREND AND PATTERN EVALUATIONS USING THE BOP.DATA BASE}

Many searches were performed on the BOP data base to look for trends and patterns in the data. The searches were performed etther by automatically querying the data base with structured dBase III program codes or by manually searching the data with embedded dBase III commands. Table 3-1 lists the initial searches performed on the BOP data base, some of which also required use of the supplementary plant data base (e.g., those involving NSSS vendor, architect/engineer, turbine-generator manufacturer). Searches addressing BOP trips per critical year per plant required use of the supplementary data base containing the critical hours data. Additional searches were performed as questions arose on the results of the initial searches.

A basic distinction was made between mature plants and new plants. Mature plants were defined as those receiving operating 1 icenses before January 1 , 198.3. Thus, all plants in the mature plart category had held an operating license (OL) at least 1 year before the start of the LER period covered by the study - January 1, 1984. This definition of mature plants resulted in a constant population of 76 plants for trend and pattern analysis. A "floating" definition of mature plants was considered but not used because it would have introduced another variable (plant population) into the trend and pattern analysis.

\subsection{BOP Trips per Calendar Year}

Table 3-2 presents the average number of BOP trips per calendar year (raw data) for the years 1984 through 1988, grouped by NSSS vendor. Mature units are distinguished from new units. The individual plant data used to compile the averages are given in Appendix B.

The data for the mature Westinghouse units show a clear downward trend, with the 1987 and 1988 values approximately half the 1984 value. This probably reflects the work of the Westinghouse Owners Group in reducing trip frequencies. Trends in the data for mature Babcock and Wilcox (B\&W) units are not as clear, but the average number of trips was reduced by a factor of 2 between 1985 and 1986, and the lower value was sustained in 1987 and 1988. The average BOP trip frequencies for mature Combustion Engineering (CE) 
Table 3-1

BOP Data Base Search Logic

1. BOP trips by plant

2. BOP trips by plant by year

3. BOP trips by NSSS vendor

4. BOP trips by architect/engineer

5. BOP trips by NSSS and architect/engineer combinations

6. BOP trips by operating license date by plant

7. BOP trips by turbine-generator manufacturer by plant

8. BOP trips by cause by year

9. BOP trips by system/ subsystem combinations

10. BOP trips by subsystem/component combinations

11. BOP trips by power level

$3-2$ 
Table 3-2

Average BOP Trips per Unit per Calendar Year (1984 through 1988)

Mature units

(OL Before Jan 83)

$\underline{1984} \quad \underline{1985} \quad \underline{1986} \quad \underline{1987} \quad \underline{1988}$

B\&W (8 units)

2.43

4.13

1.86

1.86

1.62

CE (9 units)

2.33

2.78

2.67

3.33

1.33

GE (26 units)

2.35

2.50

2.04

2.26

1.46

W (33 units)

3.36

3.00

2.97

1.52

1.76

A11 vendors

2.76

2.92

2.47

2.00

1.59

New units

(OL After Jan 83)

$\underline{1984} \quad \underline{1985} \quad \underline{1986} \quad \underline{1987} \quad \underline{1988}$

B\&W (none)
CE (2 to 6 units)
5.00
7.75
4.00
3.20
1.00

GE (3 to 11 units)

10.67

2.83

4.63

3.80

3.00

W (2 to 15 units)

10.00

10.20

6.00

7.08

3.53

All vendors

8.86

6.81

5.00

5.21

2.87 
units increased by 50 percent from 1984 io 1937 but dropped significantly in 1988. The data for mature General Electric (GE) units do not indicate a trend up or down until 1988, when the average trip rate dropped below two per year, comparable to the rates for units in the other three vendor groups.

A comparison was made between total annual BOP trip frequency as identified in this study and the frequency as identified in the previous study of BOPrelated regulatory issues performed by Mitre Corporation (Reference 1). The comparison was made for the calendar years common to the two studies, 1984 and 1985. The results are shown below.

\begin{tabular}{|c|c|c|}
\hline \multicolumn{3}{|c|}{ Total BOP Trips } \\
\hline 1984 & 1985 & $2-y r$ total \\
\hline 148 & 145 & 293 \\
\hline 179 & 251 & 430 \\
\hline
\end{tabular}

The reason for these differences is in the definition of BOP for the two studies. The BOP definition used in the Mitre study was limited to the power conversion systems (14 SCSS codes), whereas the present study included the power conversion systems plus many other systems--electrical, instrumentation and control, cooling water, air systems, etc. (47 SCSS codes).

\subsection{BOP Trips per Critical Year--Annual}

A more meaningful indication of the frequency of BOP trips of interest is the compilation of BOP trips per critical year, where the raw data per calendar year are norn, ized to the time the unit was critical. (Note that this normalization parater is not entirely consistent, because some entries in the BOP data base represent conditions when the reactor was subcritical).

Table 3-3 presents the average number of BOP trips per critical year for the years 1984 through 1988, grouped by NSSS vendor. Mature units are once again distinguished from new units. The individual plant data used to compile the averages are given in Appendix $C$. 
Table 3-3

Average BC'P Trips per Unit per Critical Year 1984 through 1988

Mature units

(OL. Before Jan 83)

$1984 \quad \underline{1985} \quad \underline{1986} \quad \underline{1987} \quad \underline{1988}$

B\&W (8 units)

3.09

7.14

3.10

2.34

2.23

CE (9 units)

3.36

3.88

3.45

4.51

1.71

GE (26 units)

$\begin{array}{lllll}4.15 & 4.07 & 3.46 & 3.68 & 2.52\end{array}$

W (33 units)

5.11

3.89

4.18

2.18

2.42

All vendors

4.36

4.23

3.77

2.97

2.33

New units

(OL After Jan 83)

1984

$\underline{1985}$

1986

$\underline{1987}$

1988

B\&W (none)

CE (2 to 6 units)

7.46

16.4

6.04

$4.13 \quad 1.28$

GE (3 to 11 units)

68.10

7.02

9.69

$6.99 \quad 4.04$

W (2 to 15 units)

$27.40 \quad 23.50$

9.24

12.20

5.02

Al1 vendors

24.40

15.80

8.53

8.66

3.93 
The trends in the critical year data are generally the same as observed in the raw (calendar year) data, i.e.:

- Westinghouse units show a clear downward trend from 1984 through 1987 with a slight increase in 1988.

- B\&W units show a downward trend after 1985.

- CE units show an upward trend, increasing by about 50 percent from 1984 through 1987, but decreasing substantially in 1988.

- GE units show a general downward trend, with a significant decrease in 1988.

- All four vendors groups show a significant improvement in BOP trip performance in 1988 versus 1984.

Table 3-4 lists the 10 "best and worst" BOP performers for the 5-year period. This information shows the range of plant performance and the distribution of "good" and "poor" performances among the NSSS vendors.

\subsection{BOP Trips per Critical Year - Cumulative Average}

Data on the cumulative average number of BOP trips per critical year, for the years 1984 through 1988, are given in Table 3-5. The individual plant data from which the averages were calculated are given in Appendix $D$. These data show remarkable consistency among the mature units of the different NSSS vendors, at slightly less than four BOP trips per critical year for 1984 through 1988, with a spread (highest to lowest) of only 18 percent. These data indicate that the conditions or parameters that cause variations in BOP trip frequency do not strongly reflect NSSS vendor, a result that is not surprising, although the degree of uniformity is somewhat surprising.

\subsection{Bup Trips by General Cause}

General causes of BOP trips defined for the purposes of this study were component failure, human-related, procedure-related, design-related, and spurious or unknown. Table 3-6 presents the breakdown of general causes of 
Table 3-4

Range of BOP Performance

(BOP Trtps, 1984-1988)

\section{Iop 10 BOP Performers}

Number of Average BOP Trtps Units NSSS BOP Trtps per Crittcal Year

$\begin{array}{lrll}\text { Pratrie Island 2 } & \text { W } & 1 & 0.2 \\ \text { Fort Calhoun } & \text { CE } & 1 & 0.3 \\ \text { Point Beach 2 } & \text { W } & 3 & 0.7 \\ \text { Point Beach 1 } & \text { W } & 3 & 0.8 \\ \text { Prairte Island 1 } & \text { W } & 5 & 1.1 \\ \text { San Onofre 1 } & \text { W } & 3 & 1.3 \\ \text { Duane Arnold } & \text { GE } & 5 & 1.4 \\ \text { North Anna 2 } & \text { W } & 7 & 1.6 \\ \text { Farley 2 } & \text { W } & 7 & 1.6 \\ \text { Quad Cities 1 } & \text { GE } & 7 & 1.8\end{array}$

\section{Bottom 10 BOP Performers}

Number of Average BOP Trips Units NSSS BOP Trips per critical Year

$\begin{array}{lrll}\text { Salem 2 } & \text { W } & 34 & 10.2 \\ \text { Grand Gulf 1 } & \text { GE } & 27 & 9.4 \\ \text { Dresden 3 } & \text { GE } & 22 & 7.2 \\ \text { Indian Point 3 } & \text { W } & 26 & 7.1 \\ \text { Rancho Seco } & \text { B\&W } & 11 & 7.0 \\ \text { Maine Yankee } & \text { CE } & 25 & 6.4 \\ \text { Davis Besse } & \text { B\&W } & 13 & 6.3 \\ \text { Indian Point 2 } & \text { W } & 23 & 6.3 \\ \text { D.C. Cook 2 } & \text { W } & 18 & 6.1 \\ \text { Diablo Canyon 1 } & \text { W } & 18 & 6.0\end{array}$


Table 3-5

BOP Trips per Crittcal Year per Unit, 5-year Cumulative Average

Mature Units

$\begin{array}{lcc}\text { NSSS Vendor } & \text { 5-Year Cumulative Average } & \text { Standard Deviation } \\ \text { B\&W (8 units) } & 3.98 & 1.75 \\ \text { CE (9 units) } & 3.40 & 1.64 \\ \text { GE (26 units) } & 4.02 & 2.44 \\ \text { W (33 units) } & 3.76 & 2.12\end{array}$

New Units

$\begin{array}{lcc}\text { NSSS Vendor } & \text { 5-Year Cumulative Average } & \text { Standard Deviation } \\ \text { B\&W (0 units) } & - & - \\ \text { CE (5 units) } & 6.31 & 2.69 \\ \text { GE (11 units) } & 10.67 & 7.31 \\ \text { W (15 units) } & 14.02 & 12.29\end{array}$


Table 3-6

BOP Trips by Cause

(A11 units 1984-1988)

\section{Cause}

Component fallure

Human-related

Design-related

Procedure-related

Spurious or unknown

Environment

other causes

\section{Percent}

46.5

30.9

5.6

5.1

4.8

1.5

5.6

100.0 
BOP trips in these categortes. The percent column is percent of causes, not trips, to account for multiple-cause events. The percent of trips is not easily extractable from the data (because of multiple cause events), but is not expected to differ markedly from the percent of causes 11 sted. The breakdown by general cause- -47 percent component fatlure, 31 percent human related, 22 percent all uther cause categorles-.ts not surprising.

By compartson, the Mitre report (Reference $1, p, x \mid x$ ) est fmated that about half the BOP trips are caused by single component fallures in the power conversion systems and about half are caused by personnel errors. As discussed in Section 3.5, this study evaluated multiple-cause events, and thus disagrees with the Mitre conclusion that about half the Bop trips are caused by single component fallures. Our estimate is about one-third are caused by single component fallures. Simllarly, our evaluation indicates that about a third, rather than half, of the BOP trips are human-related. This does not include design- and procedure-related problems as humanrelated.

A compartson with the AEOD report on scram reduction (Reference 2, Vo 1. 5) is less pertinent because the AEOD data are for all trips (not just BOP trips) and for mature plants (not all plants). Normal tzed data from the AEOD report (Reference 2, Table 3-11, p. 24) indicate, for the time pertod 1984 through 1987, that about 60 percent of the trips were caused by equipment fatlure and about 25 percent by human error.

\subsection{BOP Trips by Single or Mult tple Causes}

Table 3-7 presents the results of an evaluation of all single- and multiplecause BOP trips. Although most of the trips (70 percent) can be traced back to a single BOP cause, a significant fraction (27 percent) resulted from two causes, and a small fraction ( 3 percent) from three causes. There is a subjective element to these categorizations, but an attempt was made to distinguish those BOP trips which probably would not have occurred in the absence of a second (or third) causative mechantsm. 
Tabile 3-7

Single- and Multiple-Cause BOP Trips

(A11 untts 1984-1988)

\section{Single cause}

$\begin{array}{lc}\text { Component fatlure } & \text { Ne. ef trips } \\ \text { Human-related } & 487 \\ \text { Procedure-related } & 333 \\ \text { Design-related } & 46 \\ \text { Environment } & 34 \\ \text { Spurtous or unknown } & 4 \\ \text { Other } & 9 \\ & \end{array}$

$379(27 \%)$

Irtole cause

$39(3 \%)$

Total BOP trips $\quad 1405$




\subsection{Bop Irtps by system and subsystem}

The breakdown of BOp trips by system and subsystem is presented in Table 3. 8. The feedwater system was implicated in about 40 percent of the total BOP trips, and the feedwater control subsystem was involved in 61 percent of the feedwater-related trips. The turbine-generator $(T / G)$ system accounted for about 30 percent of the total trips; most of the turbine-gerierator-related trips, about 60 percent, involved the $T / G$ instrumentation and control subsystem. The next largest system contributors to BOP trips were the AC power systems, about 12 percent; the main steam system, about 6.5 percent; and atr systems, about 3 percent. Clearly the dominant contributors to BOP trips were the feedwater control and the $T / G$ instrumentation and control subsystems, causing about 42 percent of the total BOP trips. The detalled information on BOP trips by system and subsystem is presented in Appendix $E$.

\subsection{BOP Irlps by System and Component}

The breakdown of BOP trips by system and component, shown in summary form in Table 3-9, indicated that human error clearly dominated as the source of the fallures. The human error contribution was about one-third of the total for each of the major system contributors to BOP trips-. feedwater, turbine/generator, $A C$ power, and main steam. In each case, the next largest contributor was much smaller than the human error contribution, indicating that a very large number of individual components was involved, each contributing a very small fraction to the system fallure rates. The detafled information on BOP trips by system and component is presented in Appendix F.

\subsection{BOP Irip Frequency and Feedwater System Destan Charactertstics}

Because of the predominance of trips inttlated by feedwater system problems, an analysis was done to determine if feedwater system design characteristics were assoctated with differences in BOP trip frequency. Three aspects of feedwater system destgn were analyzed: the number of feedwater pumps, reedwater supply capactty per pump, and the type of pumps (motor-driven versus turbine driven). 
Table 3-8

BOP Trips by System and Subsystem

(All untts 1984-1988)

syste에

Number

of. Irips subsystem

Number

Foodwater

561
Feedwater control Unspectfied
Condensate
Foedwater heater
others

of Irtes

Peicent

39.9

344

135

26

23

33

Turbtne-generator

419

$$
\begin{aligned}
& \text { T/G I\&C } \\
& \text { Unspeciffed } \\
& \text { Condenser } \\
& \text { Generator } \\
& \text { lube ofl } \\
& \text { Others }
\end{aligned}
$$

29.8

\section{0}

87

33

9

8

32

AC power

168

$$
\begin{aligned}
& \text { High vollage } \\
& \text { Vital } A C(120 \mathrm{~V}) \\
& \text { Medlum voltage } A C \\
& \text { Others }
\end{aligned}
$$

12,0

77

47

31

13

90

47

Unspecifted

Molsture separator rehealer

others

6.4

3,1

Air systems

44

I\&C (general)

31

2.2 
Table 3.3

BOP Trips by Systen and Component

(Al1 untts 1984-1988)

Number

System

Feedwater

Turbine-generator

$A C$ power

Main steam

561

419

168

90 of Trios

Component

Number

of Trips

Human

FW regulating valve

213

circult card

Pump

Valves

Unknown

Human

128

Circult card

Unknown

17

25

Human

51

Transformer

23

circult breaker

10

23

21
Percent

Human-Related

38.0

30.5

30.4

Human

34

37.8

Valve

6 
The base population for this analysis was a set of 60 plants represented in the BOP data base, for which data on feedwater system characterfstics were avallable. Data on all three analysis varlables were not avatlable for all 60 plants. Thus the spectfic analysis results described below address somewhat smaller subpopulations that differ silightly in membership.

Compartson of various BOP trip rates per critical year for plants with two feedwater pumps and plants with three feedwater pumps revealed no clear advantage for etther two- or three-pump plants. For the population of 60 plants, 15 use three pumps and 45 use two pumps. Although the three-pump plants consistently performed better than the two-pump plants, the difference was not large. The results of the comparisons made are summarlzed below.

\section{Avg. Number of BOP-Related Trips per Critical Year}

\section{Iotal FW systems EW control system}

$\begin{array}{llll}\text { 2-pump FW plants } & 4.5 & 1.9 & 1.2 \\ \text { 3-pump FW plants } & 4.2 & 1.6 & 0.9\end{array}$

The number of feedwater pumps does not convey the excess pumping capacity for feedwater. Two pumps each with 50 percent capacity and three pumps with 33.3 percent capactty have the same excess pumping capacity, namely zero.

To learn the effect that excess feedwater pumping capacity might have on BOP trips, data on 51 mature plants were examined. Each plant was rated according to what percentage of full feedwater flow could be delivered with one pump out of service ("N-1 capacity"). For example, a plant that has two 50 percent rumps can supply only 50 percent if one pump is lost; a plant with three 50 percent pumps can supply 100 percent. The intent here was to determine if plants with large excess feedwater pumping capability had fewer BOP trips. There were eight plants with $N-1$ capacity of 100 percent and 13 plants with N-1 capacity of $\geq 78$ percent. The plants with N-1 capacity of 78 percent or higher experienced only very slightly improved statistics; even the plants with N-1 capacity of 100 percent were only 15 percent better (fewer trips per critical year) than the average of all of the rest. 
Clearly, excess feedwater capacity was not a major factor in creating good performers. A summary of these data is presented below. The complete data can be found in Appendix G:

\section{Avg. Number of BOP-Related Trips per Critical Year}

Total BOP FW system FW control system

$\begin{array}{lccc}N-1 \text { capacity }=100 \% & 3.8 & 1.4 & 1.2 \\ N-1 \text { capacity } \geq 78 \% & 4.2 & 1.8 & 1.4 \\ N-1 \text { capacity }<78 \% & 4.4 & 1.9 & 1.2\end{array}$

The fact that many other factors besides the capacity or number of feedwater pumps enter into BOP and feedwater trip performance can be seen in the fact. that some of the worst performers have high excess feedwater capacity and that most of the high capacity feedwater plants are not in the best performer group. In fact 3 of the top 10 performers have no excess feedwater capacity.

Finally, one trend observed during these evaluations is that most of the best performers have motor-driven feed pumps and that almost all of the worst performers have turbine-driven feed pumps. All of the top nine performers in overall BOP trips (that is, fewest trips per critical year) had motor-driven feed pumps, while five of six of the worst performers had turbine driven feed pumps. If feedwater-system-induced reactor trips are considered instead of BOP trips, six of the worst seven have turbine-driven feed pumps and eight of nine of the best have motor-driven feed pumps. Similarly, if only feedwater-control-induced reactor trips are considered, six of the seven worst performers have turbine-driven pumps, while four of the top seven have motor-driven. Summarized below is a comparison of trips at 57 plants classified by type of feedwater pumps. 
Avg. Number of BOP-Related Trips per Critical Year

Total BOP FW system FW control system

Motor driven FW plants

3.2

1.1

0.8

Turbine driven FW plants

5.5

2.3

1.5

\subsection{BOP Trips by Plant, NSSS Vendor and A/E}

Because BOP systems are the subject of this study, it is possible that the failure frequencies would show some trends or patterns as a function of the architect/engineer. The results of our searches of the BOP data base indicate that this is not the case; i.e., there are no clear patterns observet among the major $A / E$ firms who have engineered several units.

Table 3-10 presents data on A/E firms, number of plants and number of trips, grouped by NSSS vendor. The average number of BOP trips per plant was derived from Table 3-10. The results ranged from 9 to 14 trips per plant over the 5 years of data for the major A/E firms--Bechtel, Stone \& Webster, Sargent \& Lundy, and Ebasco. BOP trip data for individual plants, with NSSS vendor and $A / E$ firms identified, are presented in Appendix $H$.

\subsection{BOP Trips by Plant Age}

The BOP data base was searched for information on the age-dependence of BOP trip frequencies. The resulting data are presented in Figure 3-1 for mature plants, i.e., those receiving an operating license before January 1, 1983. The age of a unit was defined as 1986 (the middle of the study period) minus the year of the unit operating license. Each data point represents the average total number of BOP trips for units of the same age over the 5-year time period.

As can be seer. from Figure 3-1, the data are characterized by a wide scatter; the average values for plants of different age show large spikes (both up and down). A linear least squares fit of the average data provided a downward slope of about half a trip per year of plant operation, 
Table 3-10

BOP Trips by NSSS Vendor and $A / E$ Firm

(A11 units 1984-1988)

NSSS Vendor A/E Firm

B\&W

$B \& W$

$B \& W$

B\&W Total:

$\begin{array}{ll}\text { CE } & \text { Bechtel } \\ \text { CE } & \text { Ebasco } \\ \text { CE } & \text { Gibbs and Hill } \\ \text { CE } & \text { Stone \& Webster }\end{array}$

CE Total:

Bechte 1

Duke and Bechtel

Gilbert

Stone \& Webster

GE

GE

$G E$

GE

GE

$G E$

$G E$

GE

GE

GE

GE

GE Total:

Bechtel

Burns \& Roe

Detroit Edison and S\&L

Ebasco

Gilbert

Niagara Mohawk Power Corp.

Sargent \& Lundy

Southern Company and Bechtel

Stone \& Webster

TVA

United Engineers

$W$

$W$

W

W

$W$

$W$

$W$

$W$

$W$

$W$

$W$

W

$W$

$W$

$W$

$W \quad T o t a l:$

American Electric Power

Becintel

Bechtel and Sargent \& Lundy

Duke Power Company

Duquesne Light/Stone \& Webster

Ebasco

Fluor Pioneer

Gilbert

Pacific Gas \& Electric

Public Service Electric \& Gas

Sargent \& Lundy

Southern Company and Bechtel

Stone \& Webster

TVA

United Engineers

Total No. of Trips:
No. of Plants

3

27

24

89

8

110

59

1
25

195

113

54

20

17

13

10

92

33

51

8

19

430

28

108

24

77

26

36

22

30

39

50

77

17

9.1

17

49

691
37

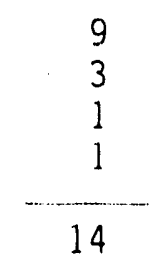

11

3

2

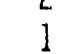

1

7

2

4

3

2

2

9

1

4

2

2

3

2

2

2

6

2

7

2

2

48 


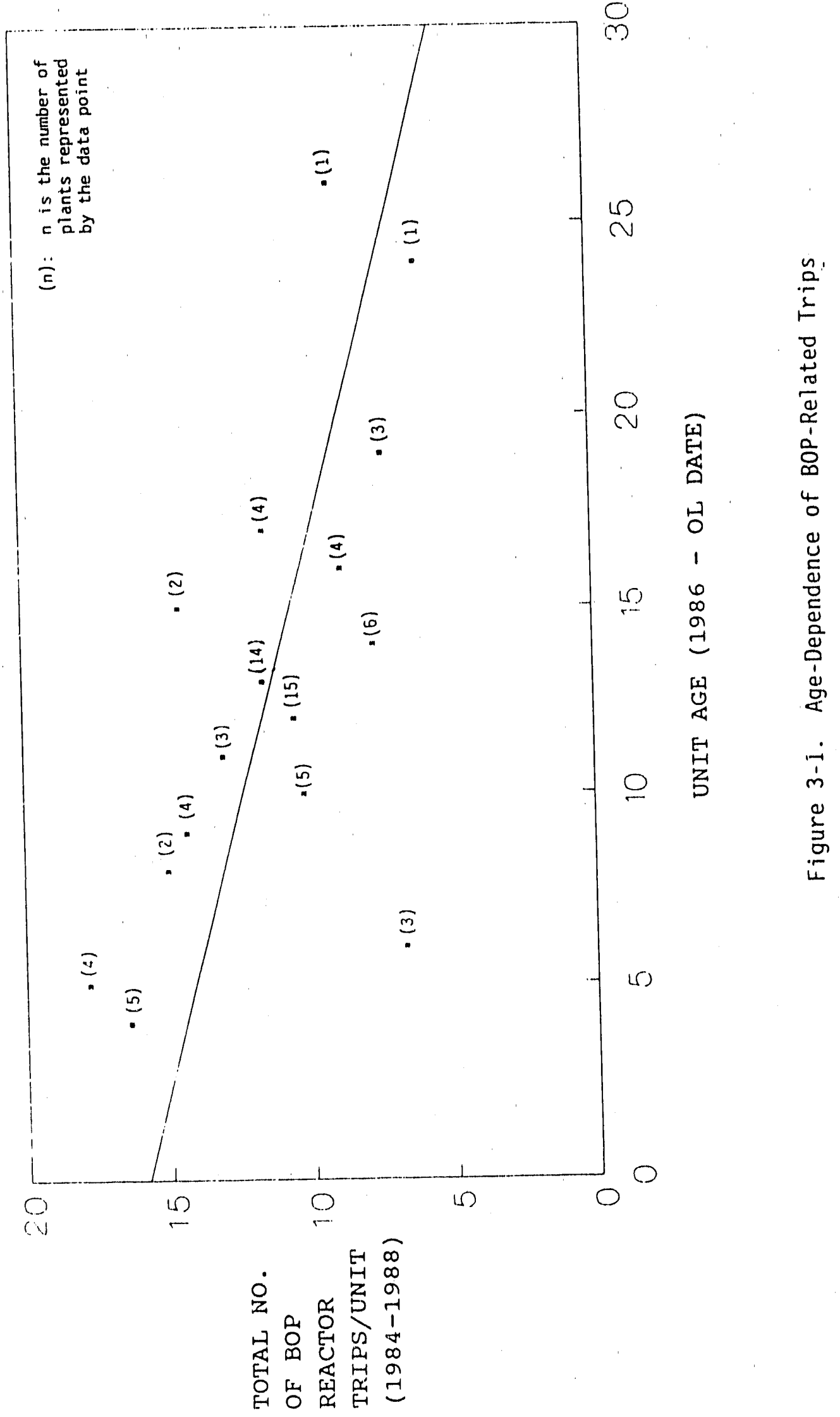


suggesting that BOP-related trips tend to decrease over the operating life of a plant.

\subsection{BOP Trips as a Function of Power Level}

A summary of the BOP trips as a function of power level at which the trips occurred is given in Table 3-11. Half the BOP trips occurred above 75 percent power, and these were dominated by turbine-generator problems. Because most plants spend mosi of their time above 75 percent, this is not a surprising result. In fact, a higher fraction might have been expected at high power. Nearly 30 perceni of the BOP trips occurred at or below 25 percent power, and these were dominated by feedwater problems. The relatively high percentage of BOP trips at reduced power levels could be an indication of the difficulty cf operating a nuclear power plant at reduced power levels. The remaining trips were divided evenly between the 25 percent to 50 percent range and the 50 percent to 75 percent range. The detailed data by plant, from which Table 3-11 was derived, are given in Appendix I.

\subsection{Origin of the Reducition in BOP Trips}

Several special-purpose searches of the BOP data base were performed to identify the origin of the dramatic reduction in the number of BOP trips between 1984 and 1988 .

Table 3-12 presents data for BOP trips by general cause by year. The top number in each set is the value for mature units only, i.e., the 76 units that received $\mathrm{OLs}$ before January 1, 1983. The bottom number in each set is the value for all units, which varied in number from 86 in 1984 to 108 in 1988. Note that the data for 1984 does not generally fit the trend, and the largest reductions are usually between the 1987 and 1988 data. Overall, both the component failure and human-related causes (by far the two largest contributors) showed substantial reductions over the 5 -year study period.

Table 3-13 shows feedwater trips by year by reactor vendor, along with normalized per-unit values, to account for the varying number of units over the time period. The total number of feedwater trips was reduced 20 percent from 1984 through 1988, in spite of a 25 percent increase in the number of 


\section{Table 3-11}

BOP Trips by Power Leve1

(A11 units 1984-1988)

\begin{tabular}{|c|c|c|}
\hline $\begin{array}{l}\text { Power Level Range, } \\
\text { Percent }\end{array}$ & $\begin{array}{l}\text { Number of } \\
\text { BOP Trips }\end{array}$ & $\begin{array}{c}\text { Percent of Total } \\
\text { BOP Triks }\end{array}$ \\
\hline $0-25$ & 398 & 28.3 \\
\hline$(0-5)$ & (137) & $(9.8)$ \\
\hline$(5-25)$ & (261) & $(18.6)$ \\
\hline $25-50$ & 148 & 10.5 \\
\hline $50-75$ & 148 & 10.5 \\
\hline $75-100$ & 711 & 50.6 \\
\hline Total BOF & 1405 & $100 \%$ \\
\hline
\end{tabular}


Table 3-12

BOP Trips by General Cause by Year

(1984-1988)

Number of Causes

\begin{tabular}{lrrrrrr}
\multicolumn{1}{c}{ Cause } & 1984 & $\underline{1985}$ & $\underline{1986}$ & $\underline{1987}$ & $\underline{1988}$ & Total \\
\cline { 2 - 4 } Component failure & $138^{*}$ & 150 & 121 & 96 & 82 & 587 \\
& 176 & 209 & 173 & $17 ?$ & 135 & 865 \\
Human-related & 76 & 99 & 78 & 62 & 37 & 352 \\
& 101 & 142 & 129 & 130 & 73 & 575 \\
Design-related & 12 & 16 & 13 & 14 & 6 & 61 \\
& 19 & 27 & 22 & 25 & 12 & 105 \\
Procedure-related & 11 & 12 & 9 & 8 & 15 & 55 \\
& 14 & 21 & 20 & 19 & 21 & 95 \\
Environment & 8 & 3 & 5 & 4 & 0 & 20 \\
& 8 & 6 & 6 & 5 & 3 & 28 \\
Unknown/spurious & 21 & 16 & 15 & 4 & 8 & 64 \\
& 23 & 22 & 21 & 13 & 11 & 90 \\
Other & & & & & & \\
Totals & 27 & 19 & 18 & 17 & 3 & 84 \\
& 31 & 24 & 20 & 23 & 6 & 104 \\
& 293 & 315 & 259 & 205 & 151 & 1223 \\
& 372 & 451 & 391 & 387 & 261 & 1862
\end{tabular}

*Top Value: Mature units only (OL before January 1, 1983) Bottom Value: All units 
Table $3-13$

Feedwater Trips by Year by Vendor

(Al1 units, 1984-1988)

NSSS

Feedwater Trips

\begin{tabular}{|c|c|c|c|c|c|}
\hline Vendor & 1984 & 1985 & 1986 & 1987 & 1988 \\
\hline$B \& W$ & $5(0.62)^{*}$ & $15(1.87)$ & $5(0.62)$ & $7(0.88)$ & $7(0.88)$ \\
\hline CE & $17(1.50)$ & $29(2.20)$ & $12(0.86)$ & $19(1.30)$ & $11(0.73)$ \\
\hline GE & $25(0.86)$ & $24(0.83)$ & $28(0.93)$ & $41(1.28)$ & $18(0.60)$ \\
\hline W & $56(1.60)$ & $69(1.77)$ & $69(1.77)$ & $60(1.36)$ & $46(0.96)$ \\
\hline Total & 103 & 137 & 114 & 127 & 82 \\
\hline
\end{tabular}


units. There were 45 fewer feedwater trips in 1988 than there were in 1987 (35 percent reduction), and half of this reduction came from GE BWRs. The number of feedwater trips per unit year decreased substantfally between 1984 and 1988 for CE, $W$, and GE untts, but increased substantlally for B\&W untts.

rable 3-14 presents data on turbine trips by year by reactor vendor, along with normalized per-untt values, to account for the varying number of untts over the time perlod. The total number of turbine trips was reduced 25 percent from 1984 through 1988, in spite of a 25 percent increase in the number of units. A large reduction of 30 trips (30 percent) occurred between 1987 and 1988, and more than half of this reduction is from $W$ units. The per-untt values show substantial reductions for all reactor vendors except B\&W, whtch stayed the same between 1984 and 1988 .

Table 3-15 presents a breakdown of human-related causes by year. Focusing on the two major contributors, operations and maintenance, once again the 1984 data does not fit the trend. There were substantial increases in the two areas between 1984 and 1985, and an even 1arger decrease in the maintenance-related causation between 1987 and 1988. Overa11, there was a 45 percent reduction in human-related BOP trips causation between 1987 and 1988, with about half the reduction coming from the maintenance area. Between 1984 and 1988, a 30 percent reduction in human causation was achieved, in spite of a 25 percent increase in the number of units.

In summary, no single factor can be identified as the major reason for the substantial reduction in BOP-related trips betweell 1984 and 1988 or, in many cases, between 1987 and 1988. In terms of general causation, fewer component fallures and fewer human errors both contributed to the reduction in BOP trips. At the systems level, both feedwater and turbine/generator related trips decreased substantially, especially between 1987 and 1988. 
Table 3.14

Turbine Trips by Year by Vendor (A11 units)

\begin{tabular}{lcccccc}
$\begin{array}{c}\text { NSSS } \\
\text { Vender }\end{array}$ & \multicolumn{1}{c}{$\begin{array}{c}\text { Feedwater Trtps } \\
\text { B\&W }\end{array}$} & $3(0.37)^{*}$ & $8(1.00)$ & $3(0.37)$ & $0(0.00)$ & $3(0.37)$ \\
CE & $6(0.55)$ & $15(1.15)$ & $15(1.07)$ & $16(1.06)$ & $4(0.27)$ \\
GE & $46(1.60)$ & $29(1.00)$ & $31(1.03)$ & $29(0.91)$ & $26(0.87)$ \\
W & $32(0.91)$ & $32(0.82)$ & $42(1.08)$ & $49(1.10)$ & $31(0.64)$ \\
Total & 87 & 84 & 91 & 94 & 64
\end{tabular}

* $(x x x)$ - average trip/untt

$3-25$ 
Table 3.15

Type of Human-Related Cause by Yoar

(A'l untts, 1984-1988)

Types of

Human-Related

\begin{tabular}{|c|c|c|c|c|c|c|c|}
\hline Cause & 1984 & 1985 & 1986 & 1987 & 1988 & Iotal. & Percent \\
\hline Operattons & 44 & 61 & 53 & 39 & 33 & 230 & 40.0 \\
\hline survelllance & 15 & 12 & 20 & 22 & 10 & 79 & 13.7 \\
\hline Matntenance & 35 & 63 & 48 & 57 & 26 & 229 & 39.8 \\
\hline Others & 7 & 6 & 8 & 12 & 4 & 37 & 6.4 \\
\hline Total & 101 & 142 & 129 & 150 & 73 & 575 & 100.0 \\
\hline
\end{tabular}




\section{Beferences}

1. NUREG, CR-4783, "Analysts of Balance of Plant Regulatory Issues, "Mitre Corporation, January 1987.

2. NUREG-12\%5, "Operattonal Expertence Feedback Report - Progress in Scram Reduction," Vol, 5, L.G, Bell and P.D, O'Rell1y, USNRC, Office for Analysis and Evaluation of Operational Data, March 1989. 


\section{INSIGHTS INTO BOP EVENTS}

This section summartzes the insights gatned from the search for trends and patterns in the 5-year, 1405 uvent BOP data base. General observations are followed by findings on BOP trips per calendar year; BOP trips per crittcal year (annual and 5-year average values); general causation of BOP trips (1.e., component fallure, human-related, design-related, etc.); multiple cause BOP trips; systems, subsystems, and components implicated in BOP trip causation; and trend observatfons by archttect/engtneer, plant age, and plant power level. For the purposes of these evaluattons, mature plants (as used for the calendar year and crittcal year data) were defined as those recelving operating licenses before January 1, 1983; a11 1ater plants were deftned as new plants.

\subsection{General Observations}

- Data on the annual average number of BOP trips grouped by NSSS vendor Indicate that the owners groups with aggresstve trip reduction programs are achieving results in the form of reduced frequenctes of BOP trips.

- Data on BOP trip causation by system and component (Appendix $F$ ) Indicate that, for the major system contributors ( the feedwater and turbine-generator systems), a majortty of the trips are caused by very small contributions from a very large number of components. This implies that to achieve further improvements, component rellability improvement programs must be very broad-based, and not focused on a few major contributors.

- Data on the general causes of BOP trips indicate that programs directed toward achteving further reductions in BOP trip frequencies will need to contain both a technical element (component, system or functional reltablity improvement) and a human performance element (fewer human errors in operation, matntenance, survetllance, and testing). 


\subsection{Spectfic Trends and Patterns}

\subsubsection{BOP Trtps per Calendar Year}

- Mature Westinghouse units on average showed a downward trend, decreasting by more than a factor of 2 between 1984 and 1987, with a slight increase in 1988, to 1.76 BOP trips per calendar year.

- Mature GE untts showed no clear trend between 1984 and 1987, but achieved a 35 percent reduction between 1987 and 1988, to 1.46 BOP trips per calendar year.

- Mature CE units showed an increasing trend of about 40 percent between 1984 and 1987, but a decrease by more than a factor oi 2 between 1987 and 1988, to 1.33 BOP trips per calendar year.

- Mature B\&W untts showed a substantial downward trend after 1985, with more than a 60 percent reduction by 1988 , to 1.62 BOP trips per calendar year. (Note: There are only elght B\&W unlts, and the unit with the least favorable BOP trip history - Rancho Seco did not operate between late 1985 and early 1988.)

- Overa11, the mature nuclear plants showed a substantial reduction in BOP trips over the 5-year pertod, from an average of $2.8 \mathrm{BOP}$ trips per calendar year in 1984 , to 1.6 BOP trips per calendar year in 1988.

The 1988 average BOP trip frequency of 1.6 trips per unit per calendar year corresponds to a total unplanned trip frequency of approximately 2.4 trips per unit per calendar year. Data from Reference 1, for the years 1980 through 1984, indicate that this level of performance for U.S. nuclear plants is approaching that for Japanese and German reactors, the world's best in terms of minimizing unplanned reactor trips. Although the data are not directly comparable, some indication of comparative performance can be drawn from the following values: 
Japan

Trips only while critical

PWRs > 1000 MWe, 1980 through 1984

0.00 to 1.50 unplanned trips per unit-year

BWRs > 1000 MWe, 1980 through 1984

0.33 to 5.00 unplanned trips per unit-year

Germany

Trips with turbine on line

PWRs, 1981 through 1984

0.45 to 1.40 unplanned trips per unit-year

BWRs, 1981 through 1984

0.99 to 2.80 unplanned trips per unit-year

The concept of what constitutes an acceptably low frequency of unplanned reactor trips also needs to be addressed. Then-ONRR Director Harold Denton, speaking at an NEA Symposium in Tokyo in April 1986, recommended a goal of achieving a trip frequency (during power operation) of no more than 2 trips per unit per year by 1990 (Reference 2). Similarly, the Institute of Nuclear Power Operations has established a 1990 goal of 1.5 unplanned automatic trips per unit per year while critical, for units with a capacity factor of 25 percent or greater (Reference 3 ).

\subsubsection{BOP Trips per Critical Year, Annual Data}

Trips per critical year is a more meaningful parameter than trips per calendar year because it reflects the fraction of time that the reactor was being operated. The trends in trips per critical year generally follow the trends in trips per calendar year, although some trends are magnified by the data on critical hours per calendar year.

- Mature Westinghouse units showed a decrease of approximately 60 percent between 1984 and 1987, followed by a 10 percent increase in 1988, to 2.42 BOP trips per critical year. 
- Mature GE units showed a clearer downward trend on a critical year basis than was evident in the calendar year data and decreased by approximately 40 percent between 1984 and 1988, to 2.52 BOP trips per critical year.

- Mature CE units showed a generally increasing trend between 1984 and 1987, followed by a 60 percent reduction between 1987 and 1988, to 1.71 BOP trips per critical year.

- Mature B\&W units showed an upward spike in 1985, but a 30 percent decrease overall between 1984 and 1988, to 2.23 BOP trips per critical year.

- Overall, the mature nuclear plants showed a substantial reduction in BOP trips over the 5-year period, from an average of 4.4 BOP trips per critical year in 1984 to an average of 2.3 BOP trips per critical year in 1988.

The values for annual average BOP trips per unit per critical year (mature plants only) compared favorably with comparable values derived from the AEOD report NUREG-1275, Volume 5 (Reference 4). The AEOD values for trips per 1000 critical hours were multiplied by 8.76 to convert to trips per critical year. The resulting values were multiplied by 0.67 to approximate the BOPrelated portion of the total trips. The resulting comparison is given below.

\author{
AEOD/SAIC Comparison \\ Annual Average BOP Trips per Unit per Critical Year \\ (Mature Units, 1984-1988)
}

$\begin{array}{lccccc} & \underline{1984} & \underline{1985} & \underline{1986} & \underline{1987} & \underline{1988} \\ \begin{array}{lccccc}\begin{array}{l}\text { From SAIC BOP } \\ \text { data base }\end{array} & 4.4 & 4.2 & 3.8 & 3.0 & 2.3 \\ \begin{array}{l}\text { Derived from AEOD } \\ \text { report data }\end{array} & 4.9 & 4.6 & 4.0 & 3.1 & 2.3\end{array}\end{array}$


Differences in the values from the two sources can be attributed to (1) differences in the definition of mature plants (AEOD used a "floating" definition; SAIC used a fixed population), (2) the approximation that BOP trips are two-thirds of the total trips, and (3) a difference in the definition of reactor trip (AEOD required control rod motion; SAIC did not).

\subsubsection{BOP Trips per Critical Year, 5-Year Average Data}

These data are quite uniform for mature plants among the four different NSSS vendors, ranging between 3.4 and 4.0 BOP trips per critical year for the 5year period. The weighted average over the period (weighted by number of plants for each NSSS vendor) is 3.8 BOP trips per critical year.

\subsubsection{Causation of BOP Trips - General}

The general causation categories defined for the BOP study were componentrelated failure, human-related, design-related, procedure-related, and spurious or unknown. Searches of the BOP data base on these parameters indicated that nearly half (47 percent) of the BOP trips were caused by one or more component failures, nearly one-third (31 percent) were humanrelated, and the other categories were minor contributors.

It hould be noted that these causation categories are not aiways clearly discernible in the LER descriptions, nor are they always clearly differentiated from each other. A design or procedural inadequacy, for example, could be termed human-related. However, in the preparation of the data base, an attempt was made to differentiate among the categories. For example, if an operator or technician correctly followed a procedure that was flawed and caused a BOP-related trip, this trip was categorized as procedure-related. If a procedure was not followed, and an incorrect or inadvertent human action caused a trip, this trip was categorized as humanrelated.

The human-related trips were further broken down as follows:

$\begin{array}{lll}0 & \text { Operations activities } & 40 \% \\ 0 & \text { Maintenance activities } & 40 \%\end{array}$


$\begin{array}{llr}0 & \text { Surveillance activities } & 14 \% \\ 0 & \text { Other activities } & 6 \%\end{array}$

A breakdown of the human-related trips as a function of activity by year (1984 through 1988) is given in Chapter 3, Table 3-15.

Both this study and the AEOD scram reduction report (Reference 4) identified equipment/component failure and human actions as the two largest

contributors to reactor trips, either total trips, in the AEOD study, or BOP-related trips, in this study. However, the fractional contributors of these two general causes were different, as shown below:

$\begin{array}{cc}\text { AEOD Study } & \text { SAIC Study } \\ \text { (Total trips, 1984-1987) } & \text { (BOP trips, 1984-1988) }\end{array}$

Equipment/component

$63 \%$

$47 \%$

failure

Human-related

$25 \%$

$31 \%$

This indicates that the human contributors to reactor trips originating in NSSS-related systems is smaller than it is in trips originating in BOPrelated systems.

\subsubsection{Multiple-Cause BOP Trips}

Approximately 70 percent of the BOP trips were determined to be single-cause events. However, a substantial proportion (27 percent) would not have occurred in the absence of a second condition, and a few trips ( 3 percent) would not have occurred in the absence of two additional conditions.

An example of a double-cause trip is a situation where one channel of a BOPrelated.trip parameter instrument has failed undetected, and a second channel is actuated or taken out of service for testing, causing a trip.

One of the counter-intuitive findings of the study was that about 30 percent of the BOP trips are categorized as multiple-cause events. A detailed review of the data base entries for multiple-cause events indicates some 
"softness" in the data, and different reviewers might have categorized some events differently. However, it is evident that multiple-cause trips are more prevalent than previously assumed by many observers, and this finding has implications for statistical and risk assessment analysts. Most of the multiple-cause trips were not from coincident independent failures or common-cause events, but rather from pre-existing conditions (e.g., degraded operability states of various systems or components) that were revealed when a related system or component was actuated.

\subsubsection{Causation of BOP Trips - Systems Implicated}

The two largest system contributors to BOP trips were the feedwater system, causing 40 percent of the trips, and the turbine-generator system, contributing about 30 percent. The next largest contributors, the $A C$ power and main steam systems, contributed about 12 percent and 6.5 percent, respectively. Other systems, contributing 3 percent or less to BOP trips over the study period, include air, circulating water, DC power, and instrumentation and control systems.

There is general agreement among recent studies that problems in the condensate/feedwater system are the leading cause of BOP-related (as well as tota1) reactor trips. The next largest system contributor to reactor trips is the turbine/generator system. Together, these two systems cause about 70 percent of the BOP trips and about half of the total reactor trips. Table 4-1 compares this study's estimates of system contributors to BOP-related trips to those derived from the AEOD report (Reference 4) and from the Mitre report (Reference 5). The Mitre estimates are considered somewhat distorted because they consider only the power conversion systems and not $\triangle C$ and DC power, water systems, air systems, etc. Other differences in the studies are mature plants versus all plants, trip definitions, and the time periods of the studies.

\subsubsection{Causation of BOP Trips - Subsystems Implicated}

Feedwater control was the dominant contributing subsystem to feedwaterrelated BOP trips. Within the turbine-generator system, the dominant contributing subsystem was instrumentation and control, primarily the electro-hydraulic control (EHC) subsystem. Feedwater control and 


\section{Table 4-1}

$$
\text { Comparison of Estimates of }
$$

Initiating System Contributors to BOP-Related Reactor Trips

\section{Percent of BOP Trips}

$\begin{array}{lll}\text { SAIC } & \text { AEOD* } & \text { Mitre**} \\ \text { Study } & \underline{\text { Study }} & \underline{\text { Study }}\end{array}$

$\begin{array}{lccc}\text { Condensate/feedwater system } & 40 & 43 & 50 \\ \begin{array}{l}\text { Turbine/generator system } \\ \text { AC power systems }\end{array} & 30 & 27 & 29 \\ \text { Main steam system } & 12 & 15 & - \\ \text { Others } & 6.5 & 8 & 7 \\ & 11.5 & 7 & 14\end{array}$

* Data from Table 3-13 of Reference 4 renormalized to include only BOP systems.

** Data derived from Table 2-11 of Reference 5. 
turbine/generator I\&C subsystem problems (component fallure or humanrelated) together caused about 40 percent of the total BOP trips.

The AEOD report, NUREG-1275, Volume 5 (Reference 4) also identifted the feedwater control and turbine/generator EHC subsystems as major contributors to reactor trips.

\subsubsection{Causation of BOP Irips - Components Implicated}

The clearly dominant "component" contributor to BOP trips was the human, generally causing about 30 percent of a 11 BOP trips across the major system contributors. The next largest component contributors, generally much less significant than the human, were pumps, valves, electrical switchgear, and circuit cards. For the dominant systems, the data are characterized by a majority of the trips coming from very small contributions from very large numbers of components.

The AEOD scram reduction study (Reference 4) indicates that problems with feedwater regulating valves and feedwater pumps each contribute about 20 percent to the frequency of feedwater-related trips. This study, which examined component contributions in detail (see Appendix F) estimates that contributors from these components are less than half as large as the AEOD estimates, in the range of 7 to 8 percent each. This difference is probably attributable to different treatment of the human "component" in the two studies.

The ract that large numbers of components are each contributing sma11 amounts to the feedwater-related BOP trips complicates resolution of the issue, and points toward using "integral" measures such as the adjustments to steam generator level trip setpoints being pursued by the Electric Power Research Institute in conjunction with the PWR Owners Groups.

\subsubsection{Trends in BOP Trips as a Function of Architect/Engineer}

The BOP data base was searched to see if positive or negative performance in terms of BOP trips could be correlated with the architect/engineer ( $A / E$ ) responsible for designing the BOP. For the major $A / E$ firms that have designed several nuclear units--Bechte1, Stone \& Webster, Sargent \& Lundy 
and Ebasco--no clear trends were evident in the data as a function of the $A / E$ firm that designed the BOP.

\subsubsection{Trends in BOP Trips as a Function of Plant Age}

The data on BOP trips as a function of plant age were widely scattered; even the annual average values at a given age showed a large degree of variablitty. The overall trend, determined by a linear least squares fit of the annual average data, showed a reduction of about one BOP trip (during the 5 years considered in the study) for every 2 years of increasing age.

\subsubsection{Irends in BOP Trips as a Function of Power Level}

Approximately half of the BOP trips observed over the study pertod occurred above 75 percent power, and those trips were dominated by problems in the turbine-generator system. Nearly 30 percent of the observed trips occurred below 25 percent power, and they were dominated by problems in the feedwater system. The remaining trips were distributed evenly between the 25 percent to 50 percent range and the 50 percent to 75 percent range in power 1 evel.

Because most nuclear units spend most of their time about 75 percent power, it is surprising that only about half of the BOP-related trips occur in this power range. The fraction of BOP-related trips at high power levels is expected to increase as plant operators resolve feedwater control problems at the lower power levels, e.g., steam generator level instabilities, or the transition from manual to automatic feedwater control. 


\section{References}

1. "Comparattve Overview of Selected Scram Statistics, "USNRC Offtce for Analysis and Evaluation of Operational Data, Proceedings of an NEA Symposium, Redicting the Frequency of Nuclear Reactor Scralis, Tokyo, Japan, Aprt1 1986.

2. "Reactor Scrams in the Untted States, A Regulator's Point of Vtew," H.R. Denton, Director, ONRR, USNRC, Proceedings of an NEA Symposium, Reducing the Frequency of Nuclear Reactor Scrams, Tokyo, Japan, Aprt1 1986.

3. "1988 Performance Indicators for the U.S. Nuclear Power Industry," Institute of Nuclear Power Operations, March 1989.

4. NUREG-1275, Volume 5, "Operating Expertence Feedback Report - Progress in Scram Reduction, Commercial Power Reactors, "USNRC, Office for Analysis and Evaluation of Operational Data, March 1989, with Addendum.

5. NUREG/CR-4783, "Analysis of Balance of Plant Regulatory Issues, "Mitre Corporation, January 1987. 


\section{EVALUATION OF RISK IMPLICATIONS}

The objective of this task was to evaluate the impact of BOp related events on the risk, as measured by estimlated core melt frequency, of nuclear power plant operation. The task was divided into two parts. First, a quantltative analysis was performed to estimate the risk impact of reactor trips caused by BOP system fallures. Second, a qualttattve evaluation was performed of the impact of BOP-related events on safety system avallablltty; this evaluation addressed events that did not necessarily result in a plant trip but did degrade the capability of a safety system.

The risk impact of BOP-related reactor trips was estimated by a parametric analysis of six probabilistic risk assessments (PRAs). Data on trip inttiating events were selected from the BOP data base, representing "good" and "bad" BOP performance plants (as defined based on frequency of BOP. related trips). These inttlating event data were used to replace the trip frequency used in each of the PRAs for inttlating events such as turbine trip and loss of feedwater. The estimated core melt frequency was then recalculated and an assessment was made of the change in core melt frequency for each PRA using tts data, the "good" performance data, and the "bad" performance data.

The impact of BOP-related events on safety system avatlability for events other than BOP-initlated reactor trips cannot be simply evaluated. Events have occurred, as reported in L.ERs, in which BOP system fatlures affected safety systems. It is difficult, however, to quantify the effects because of 1 ack of consistency within the data base and lack of total system data (particularly an indication of the number of successful component demands). Therefore, a qualitative evaluation was performed, using data from the NRC's Accident Sequerice Precursor Program. By identffying the BOP..related inttlating events within the population of Precursor events, an estimate was made of the importance of BOP systems to accident sequences involving safety system degradation (i.e., sequences characterized by inadequate core cooling and resultant core damage). 


\subsection{Impact of Bop Sxstem Performance on Plant Core Melt Erequency}

To evaluate the Impact of BOP system performance on calculated core melt frequencles, stx PRAs, representing five different nuclear power plants, were selected:

- "Connecticut Yankee Probabilistic Safety Study" (Reference 1).

- "Probab111stic Risk Assessment: L.fmertck Generating Station" (Reference 2).

- "A Review of the Limerlck Generating Station Probabilistic Risk Assessinent" (Reference 3).

- "M+11stone Unit 1 Probabtlistic Safety Study" (Reference 4).

- "A Review of the Mi11stone 3 Probabilistic Safety Study" (Reference 5).

- "Oconee PRA: A Probabtlistic Risk Assessment of Oconee Unit 3" (Reference 6).

(Note: "PRA" is used as a genertc term in this section, encompassing both the probabilistic safety studies and the probabilistic risk assessments 1isted above.)

These stx PRAs provided analytical frameworks for estimating the effects of BOP system fallures on risk as measured by calculated plant core melt frequency. The BOP-related transtent inttiator frequenctes used in each PRA were varted according to the irequencies of actual BOP-related reactor trip causes, as extracted from the BOP data base developed for this study.

The frequenctes of actual BOP-related reactor trip causes were drawn from a subset of the events in the BOP data base. Only mature plants were considered (plants that recelved an operating 1 icense before January 1 , 1983). From the mature plants, the 10 plants with the best Bop trip performance and the 10 plants with the worst BOP trip performance during the 
pertod 1984 through 1987 ware selected. Best and worst performance ware determined based on the frequency of BOp-related trips per crittical year.

A wide range of BOp trip performance resulted. The 10 plants with the bost performance had 36 BOp-related plant trips during the 4-year pertod 1984 through 1987, an average of 0.9 trips per plant per year. The 10 plants With the worst BOP performance had a total of 194 BOP.related plant trips for the same time perlod, an average of 4.85 trips per plant per year. In addition, the worst performers generally had lower avallabllity factors for the 4 years studied. This results in a larger difference between the best and worst performers when trips per crittcal year are used as the basts for compartson.

The transient inttlator categorles used in the PRAs were maintatned. Trip causes from the BOP data base were assigned to the approprlate PRA categortes.

Each PRA grouped transient inttiators in a slightly different way. The Connecticul Yankee PRA, for example, separated BOP-related inttlators into General Plant Transtents, Loss of Feedwater Events, Inadvertent Opening of a Rellef Valve Events, and other system-fallure-related transtents (e.g., Loss of Service Water). In comparison, the Mt11stone Untt 1 PRA separated the BOP-related inttiators into Transients, loss of Feedwater Translents, and Loss of the Power Conversion System (PCS) Transients.

For each of the PRAs, the data on actual BOp-related plant trip causes were combined and used in the manner most consistent with the transtent inttlator categortes in the PRA. For example, the Oconee 3 and M+1lstone 1 PRAs used both a Loss of Feedwater and a Loss of PCS transient inttlator category; thus both categorles were used in the categorization of the BOP study data applicable to the Oconee 3 and Mt1lstone 1 PRAs. However, the remaining PRAs used only a loss of Feedwater or a Loss of PCS inttiator; thus, for those PRAs, the BOP data were combined so that each BOP-related trip event contributed to the approprtate PRA transient inttlator category. Stmilarly, the Connectlcut Yanke PRA was the only one to handle the Inadvertent Opening of a Rellef Valve as a separate transient inttiator. Thts category was therefore included in the analysis of cornectlcut Yankee, but for the remaining PRAs this type of event was treated as a Plant Transiont. 
Table 5-1 shows the number of BOP-related trips that occurred during the 4year analysis pertod in each applicable PRA translent inftiator category; the "good" and "poor" BOP performance plants are compared. Table 5-2 shows the average frequency of BOP.related trips in each translent inttiator category, per calendar year and per crittcal year, over the 4-year pertod. As in Table 5 1, "good" and "poor" performance plants are compared.

The data from Table 5-2 were used to modify the transtent initiator frequenctes in each of the PRAs. The BOp-related trips per critical year were converted to an equivalent trips per calendar year using the following equation:

$$
F_{p}=F_{B O P} \cdot A_{p}
$$

where $\quad F_{p}$ anitiator frequency for use in plant PRA

$F_{B O P}$ - Inttlator frequency from BOP data base (trips per crittcal year)

$A_{p}=$ Plant avallabllity factor

For example: The General Plant Transient category for the Connecticut Yankee PRA is equivalent to the Plarit Transients category of Table 5-2. The average frequency of Plant Transtents for the "good" performance PWRs from Table 5-2 is 0.82 per crittcal year. Connecticut Yankee had an avallability factor of 0.713 . Therefore, the frequency of Plant Transtents at Connecticut Yankee, using the data for the "good" PWR plants would be:

$$
\begin{aligned}
F_{p} & =(.82)(.713) \\
& =.58 / \mathrm{yr} .
\end{aligned}
$$

The BOP-related trip frequenctes were converted to trips per crittcal year and then back to trips per calendar year when used in the PRAs for two reasons. First, the 10 plants in the "poor" BOP performance group had generally lower avallablltty factors than the 10 plants in the "good" BOP performance group. In particular, some of the plants with lower avallabllity factors had oxtended pertods (in one case, over 2 years) during which the plant was not operating. By converting to trips per critical year, these perfods of plant tnactivity were eliminated and no longer distorted the intitator frequency calculations. Second, the events included 


$$
\text { Table 5-1 }
$$

BOP Induced Transtents

Based on 1984-1987 LER Data

\begin{tabular}{|c|c|c|c|c|c|c|}
\hline Transtent & "Good" & Performance & Plants & "Poor" & Performance & Plants \\
\hline Inttiator Category & PWR & BWR & Lotal & PWR & BWR & Total \\
\hline Plant Transtents & 21 & 7 & 28 & 117 & 30 & 147 \\
\hline Loss of Main Feadwater & 3 & 1 & 4 & 8 & 12 & 20 \\
\hline Loss of Power Converston & 3 & 1 & 4 & 6 & 20 & 26 \\
\hline \multicolumn{7}{|l|}{ Steam Line Relief } \\
\hline Valve Opens & 0 & 0 & 0 & 1 & 0 & 1 \\
\hline
\end{tabular}


Table 5-2

Average Frequency of BOP-Induced Transients

Based on 1984-1987 LER Data

Transient

Initiator Category
Trips Per Year PWR BWR
Trips Per Critical Year Total
PWR BWR

"Good" Performance Plants

$\begin{array}{lllllll}\text { Plant Transients } & 0.66 & 0.88 & 0.71 & 0.82 & 1.24 & 0.89 \\ \text { Loss of Main Feedwater } & 0.09 & 0.13 & 0.10 & 0.12 & 0.18 & 0.13 \\ \text { Loss of PCS } & 0.09 & 0.13 & 0.10 & 0.12 & 0.18 & 0.13\end{array}$

"Poor" Performance Plants

Plant Transients

4.20

2.50

3.70

6.80

4.6

6.20

Loss of Main Feedwater

0.29

1.00

0.50

0.47

1.8

0.84

Loss of PCS

0.21

1.70

0.65

0.36

3.1

1.10

Steam Line Relief

Valve Opens

0.04

0.00

0.03

0.06

0.0

0.04 
in the BOP data base generally occurred at power. (There are some exceptions.) The data base for the 10 "good" and 10 "poor" performance plants is therefore restricted to 23.7 reactor years for the "poor" plants and 31.3 reactor years for the "good" plants.

The data conversion described above was used to produce plant-specific, BOPrelated transient initiator frequencies. The results are presented in Table 5-3, along with the initiator frequencies used in the PRAs.

For the different plant transients considered, two PRA frequencies are given in Table 5-3. The first is the frequency used for all events contained within this category. The second frequency, listed as "PRA (BOP)," is a subset containing only those events associated with the BOP. Excluded from this group are the reactor transients such a spurious safety injection, spurious RPS actuation, etc.

It can be seen from Table 5-3 that the initiator frequencies used in the PRAs tend to be within the range of the data for the "good" and "poor" performance plants. There are a few exceptions. The most notable exception is the Millstone 1 Loss of Feedwater initiator frequency. This frequency is more than 30 percent less than the frequency obtained from the BOP data base for "gol. 'performance BWRs. The Millstone 1 PRA used plant-specific data as the basis for its Loss of Feedwater initiating event frequency. Except for this one case, a!l six PRAs used data that, in comparison with the data derived from the BOP data base, are either within the expected range or conservative (i.e., higher than the "poor" performance plant data from the BOP data base).

The data in Table 5-3 were used to modify the core melt frequency calculations of each PRA. The first step was to determine the contribution to core melt frequency of each transient initiator as presented in the PRA. In some cases, only the dominant core melt accident sequences were provided in the PRA report; in other cases, the total contribution from each initiator was available. The next step was to replace the transient initiator frequencies used in the PRA with the LER-based, "qood" and "poor" initiator frequencies shown in Table 5-3. After this substitution, the core melt frequencies attributable to BOP-related transients were calculated. 
Table 5-3

Comparison of PRA Transient Initiator Frequencies to BOP-Related Transient Initiator Frequencies

Based on 1984-1987 LER Data (events/yr)

\begin{tabular}{|c|c|c|c|}
\hline & $\begin{array}{l}\text { Loss of } \\
\text { Main }\end{array}$ & Loss of Power & $\begin{array}{l}\text { Inadvertent } \\
\text { Steam Relief }\end{array}$ \\
\hline arit Ira & Feedwater & Conversion System & Valve Opening \\
\hline
\end{tabular}

Connecticut Yankee

$\begin{array}{lllll}\text { PRA (al1) } & 3.14 & - & \cdots & \cdots \\ \text { PRA (BOP) } & 1.93 & 0.36 & - & 4.2 E-3 \\ \text { Good plants } & 0.58 & 0.17 & \ldots & 0.00 \\ \text { Poor plants } & 4.80 & 0.59 & \ldots & 0.04\end{array}$

Limerick (PECO)

PRA (a11)

PRA (BOP)

Good

Poor
3.98
$3.63(1)$
0.77
2.80

-

$1.78(2)$

0.22

3.00

Limerick (BNL)

PRA

$8.17^{(3,4)}$

0.77

2.80

$-$

$1.23^{(5)}$

Good

Poor

3.11

2.67

1.04

3.86

0.096

0.15

0.22

$-$

3.00

Millstone 1

PRA (BOP)

Good

Poor

2.60

0.435

0.15

1. 51

Millstone 3 (LLL)

PRA (all)

7.24

PRA (BOP)

3.73

Good

0.55

Poor

4.60

$\begin{array}{ll}-. & - \\ - & 2.32 \\ - & 0.16 \\ - & 0.60\end{array}$

Oconee

PRA

Good

Poor

$\begin{array}{lll}5.70(3,6) & 0.64(7) & 0.21 \\ 0.62 & 0.09 & 0.09 \\ 5.20 & 0.36 & 0.27\end{array}$

(1) Becomes 3.2 for ATWS sequences

(2) Becomes 2.2 for ATWS sequences

(3) Insufficient information to separate Reactor Trips from BOP Trips

(4) Becomes 7.39 for ATWS sequences

(5) Becomes 2.01 for ATWS sequences

(6) Becomes 7.0 for some sequences (all transient initiators combined)

(7) Eecomes 0.7 for ATWS sequerices 
The following is an example using the General Plant Transient initiator category for the Connecticut Yankee PRA. The frequencies for this transient initiator category are: 3.14/year using data in the PRA; $0.58 /$ year using the "good" plant performance data from the BOP data base; and 4.8/year using the "poor" plant performance data from the BOP data base. The connecticut Yankee PRA provided a total core melt frequency contribution of $5.34 \mathrm{E}-5 /$ year for the accident sequences initiated by a General Plant Transient. From this iniurmation, the conditional probability of a core melt at connecticut Yankee, given a General Plant Transient initiator, is

$$
\frac{5.34 E-5 / \text { year }}{3.14 / \text { year }}=1.70 E-5
$$

Using the data derived from the BOP data base, the BOP-transient-induced core melt frequency for Connecticut Yankee would be $9.5 \mathrm{E}-6 /$ year (using the "good" plant performance data) or $8.2 \mathrm{E}-5 /$ year (using the "poor" plant performance data).

Similar calculations can be made for the Loss of Feedwater transient initiator and the Inadvertent Opening of a Relief Valve transient initiator. The results of these calculations for Connecticut Yankee are shown in Table $5-4$.

Table 5-5 shows the final results for each of the PRAs examined as part of this risk impact evaluation. Two sets of results are provided for the Limerick plant. The first set is based on the PRA performed by the utility, Philadelphia Electric Company (PECO); the second set is based on the results of the Brookhaven National Laboratory (BNL) review of the PRA. The BNL review resulted in an estimated core melt frequency an order of magnitude higher than the original utility assessment. Because of this disparity, both PRAs were evaluated.

In the evaluation of both the Limerick PRA review performed by BNL and the Oconee 3 PRA, it was not possible to separate the BOP transients from the reactor transients in the general Plant Transients initiator category. The totals for the "good" and "poor" core melt frequencies for these two PRAs are therefore slightly low because they do not include the contribution of reactor transients to the core melt frequency. However, the difference 
Table 5-4

Contributions to Core Melt Frequencies at

Connecticut Yankee Due to Changes in

BOP-Related Transient Initiator Frequencies

$\begin{array}{lccc} & \text { PRA } & \begin{array}{c}\text { Low BOP } \\ \text { Transient* }\end{array} & \begin{array}{c}\text { High BOP } \\ \text { Transient* }\end{array} \\ \text { General plant transient } & 5.3 E-5 / y r & 9.5 E-6 / y r & 8.2 E-5 / y r \\ \text { Loss of main feedwater } & 3.8 E-5 / y r & 6.4 E-6 / y r & 2.2 E-5 / y r \\ \text { IORV } & 5.9 E-6 / y r & - & 5.9 E-5 / y r \\ \text { Other } & 4.7 E-4 / y r & 4.7 E-4 / y r & 4.7 E-4 / y r \\ \quad & & & \\ \quad \text { Total } & 5.5 E-4 / y r & 4.9 E-4 / y r & 6.3 E-4 / y r\end{array}$

* CMF calculated using study data on the frequency of BOP-related transient initiators at PWRs rated best/worst in terms of BOP performance. 
Table 5-5

Summary of Calculated Core Melt Frequency Results

$\operatorname{CMF}(/ y r)$

$\begin{array}{ll}\text { Low BOP } & \text { High BOP } \\ \text { PRA } \quad \text { Iransient (1) } & \text { Iransient (1) } \triangle{ }^{\prime C M F} \\ \end{array}$

Cornecticut Yankee

$5.5 E-4$

$4.9 E-4$

$6.3 E-4$

$1.5 \mathrm{E}-4$

Limerick (PECO)

$1.5 \mathrm{E}-5$

$9.6 E-6$

$1.7 \mathrm{E}-5$

$7.3 E-6$

Limerick (BNL)

$1.0 \mathrm{E}-4$

$5.3 E-5(3)$

$1.5 E-4(3)$

$9.6 \mathrm{E}-5$

Millstone $1(\operatorname{Rev} 0)$

$8.1 E-4$

$8.0 E-4$

$3.5 \mathrm{E}-3$

2.7E-3

Milistone 3 (LLL)

$1.0 \mathrm{E}-4$

9.1E-5

$9.6 \mathrm{E}-5$

$4.4 \mathrm{E}-6$

Oconee 3

$5.4 \mathrm{E}-5$

$4.6 E-5(3)$

$5 \cdot 3 E-5^{(3)}$

6.7E-6

(1) CMF calculated using study data on the frequency of BOP-related transient initiators at 10 best and 10 worst BOP trip performance plants.

(2) $\triangle C M F=$ High BOP Transient CMF minus Low BOP Transient CMF.

(3) This does not include the contribution from reactor transients. 
between the "good" and "poor" core melt frequencies is accurate since the contribution of reactor transient initiated core melt sequences would be the same for both cases.

As can be seen from Table 5-5, the impact on the core melt frequencies of the six PRAs varied considerably from plant to plant. The impact was greatest for Millstone 1, where an increase of $2.7 \mathrm{E}-3 /$ year resulted from the use of the high BOP transient frequency versus the use of the low BOP transient frequency, i.e., "poor" plant data versus "good" plant data. This increase is due to two factors. One is the relatively high frequency of transients initiated by a loss of feedwater at the "poor" BOP performance BWRs. The second is the unique design of the Millstone 1 high pressure injection system. Millstone 1 utilizes the feedwater system to provide high pressure injection. Therefore a loss of feedwater not only trips the plant but also results in the failure of the high pressure injection system. (From plant specific data, the Millstone 1 PRA used a Loss of Feedwater initiator frequency lower than the corresponding "low BOP transient" frequency from the study data, 0.096 versus 0.15 ).

For the remaining plants the impact of the BOP system transients varies from 4 percent to nearly 100 percent of the total core melt frequency. Using the delta between the core melt frequencies resulting from the use of "good" and "poor" plant data as the measure of the impact of BOP system behavior, the three PWRs showed the least impact due to BOP related events; for all three PWRs, the difference was less than 30 percent. This is due in part to the smaller differences between the "good" and "poor" plant data for the Loss of Feedwater and Loss of PCS transients for PWRs compared to the BWR data. But it is also indicative of the contribution of BOP-related transients to the total core melt frequencies for BWRs and PWRs. In the BWR PRAs considered, BOP-related transients contributed a third or more of the total core melt frequency. For the PWR PRAs the BOP-related transients contributed only approximately 10 percent of the total core melt frequency. BOP-related transients contributed significantly more to the core melt frequencies of BWRs than PWRs, and the results of BWR PRAs are therefore affected by changes in BOP transient frequencies to a greater extent than the results of the PRAs for PWRs. 
The events for the "good" and "poor" performance plants in the BOP data base have been categorized as Plant Transients, Loss of Feedwater events, Loss of PCS events and in one case a Spurious Opening of a Steam Relief Valve. This set of events does not include all of the types of BOP initiators generally found in a PRA. System failures that cause a plant trip and also affect the operability of systems used to mitigate the consequences of a plant trip are also considered as initiating events. For example, loss of air is considered as an initiating event that usually causes a plant trip, a loss of feedwater, and a degraded operating condition for the auxiliary feedwater (AFW) system in PWRs. These events can also be considered BOP-related transient initiators, and in some cases they contribute a significant fraction of the core melt frequency for a plant.

The analysis discussed above addressed the difference in plant risk due to the difference between the reliability characteristics of "good" and "poor" performance plants. Because the types of system fallures that could trip a plant and also degrade a mitigating system's performance did not appear in the data for the "good" and "poor" performance plants, no difference in plant risk due to those types of failures could be calculated. Those types of fallures generally have relatively low frequencies, on the order of $1 E$ 3/year. It is therefore not surprising that there are no such events in the limited portion of the data base used in this analysis, which represents only approximately 55 critical years of reactor operation. The data base did include some partial fallures of support systems, for example $A C$ power and air systems. Those failures resulted in either a trip or a trip and loss of feedwater and were included in the categories used in the analysis.

Table 5-6 presents data that more completely address the importance of BOP systems to plant risk. This tatle includes the delta risk calculations described previously but it also includes the total contribution of BOP. related transient initiators as calculated in the six PRAs. This table shows that for the PWRs (Connecticut Yankee, Millstone 3, and Oconee 3), the contribution of BOP-related transients is significantly higher than the delta risk calculations would imply. The BOP support system initiators contribute more to the PWR PRA results than to the BWR PRA results. Although the delta risk calculations for the PWRs show a relatively minor impact on plant risk (as little as a 4 percent change) the importance of all BOP-related initiating events is somewhat greater. 
Table 5.6

Coniribution of BOP-Related Transtents to Core Melt Frequency

$$
\text { Plant }
$$

\begin{tabular}{|c|c|c|c|c|}
\hline $\begin{array}{l}\text { Total } \\
\text { CMF (/yr) }\end{array}$ & $\begin{array}{l}\text { BOP-Related } \\
\text { CMF }(/ y r)^{*}\end{array}$ & $\%$ & $\begin{array}{c}\text { BOP } \\
\triangle C M F(/ y r)^{+}\end{array}$ & $\begin{array}{c}\% \text { of } \\
\text { Iotal CME }\end{array}$ \\
\hline
\end{tabular}

BWR
Limertck (PECO)
$1.5 E-5$
$7.8 E-6$
52
7. $3 E-6$
49
Limerick (BNL)
1. OE-4
$<5.9 E-5$
$<59$
$9.6 \mathrm{E}-5$
96
Millstone 1
8. $1 \mathrm{E}-4$
2. $9 E-4$
$36 \quad 2.7 E-3$
333

PWR

Connecticut Yankee

Mil1stone 3

$5.5 E-4$

$8,1 E-5$

$1.4 \mathrm{E}-5$

15

1. $0 E-4$

$<2.8 \mathrm{E}-5$

14

1.5E-4

27

Oconee 3

$5.4 E-5$

$<52$

4. $4 \mathrm{E}-6$

$6.7 \mathrm{E}-6$

4

12

(*) CMF due to transients initiated by events involving BOP systems

$(+)$ The difference between the $p l a n t$ CMF using "good" and "poor" BOP performance plant data 


\subsection{BOp Influence on Accident Procurser Events}

The three most recent reports from the Acctdent Sequence Precursor Program (References 7-9) were examtned to evaluate the influence of BOP fallures on accident precursor events.

The Acctdent Sequence Precursor Prograin reviews reports (LERs) of operational events at light water reactors to identify and categortze precursors to potential severe core damage acctdents. The accident sequences considered in the program are those which could lead to tnadequate core cooling. Accldent sequence precursors are defined as events that are important elements in those accident sequences characterized by inadequate core cooling and resulting core damage. The precursor events of interest could be elther initlating events or events that contribute to such sequences subsequent to the sequence initiator. This BOP influence evaluation focused exclusively on inftlating events.

During 1984, approximately 2400 LERs were prepared by 1 itcensees to report operational events in accordance with NRC reporting requirements. Of these 2400 events, approximately 900 were selected for detafled review, and 48 of these weru judged to meet the definttion of accident precursor events. After inserting these events into the appropriate places of accident sequence event trees and quantifying the sequences, 18 were estimated to have an assoctated conditional probability of severe core damage $\geq 1 \times 10^{-4}$. That $i s$, given, the precursor event, there was a probability $\geq 1 \times 10^{-4}$ that the operability states of other systems and components would be such that inadequate core cooling and severe core damage would result. Information on these 18 precursor events is provided in Table 5-7.

Eleven of the 18 precursor events with a comparatively high probability of core damage had BOP inttiators. These are also identified in Table 5-7 and consist of five feedwater/condensate system degradations, two station transformer fatlures that caused loss of offstte power, and four one-of-akind events (main generator bearing fatlure, MSIV spurtous closure, motsture separator high-level trip, and a curvetllance procedure inadequacy). Seven of the 18 comparatively high-probabtlity core damage precursor events did not have BOP initiators. 


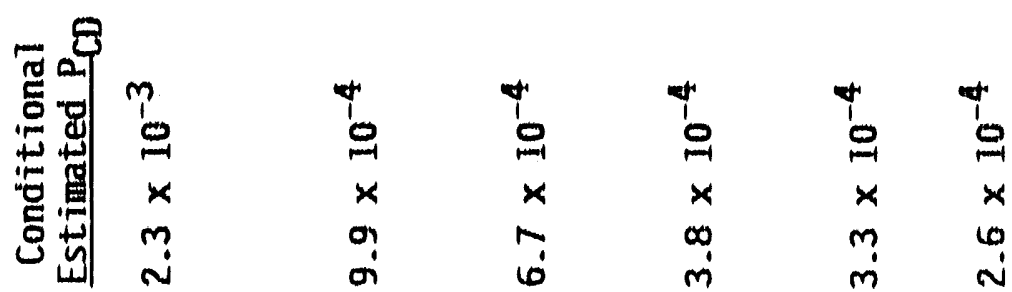

营<smiles>[C-]=[Co]</smiles>

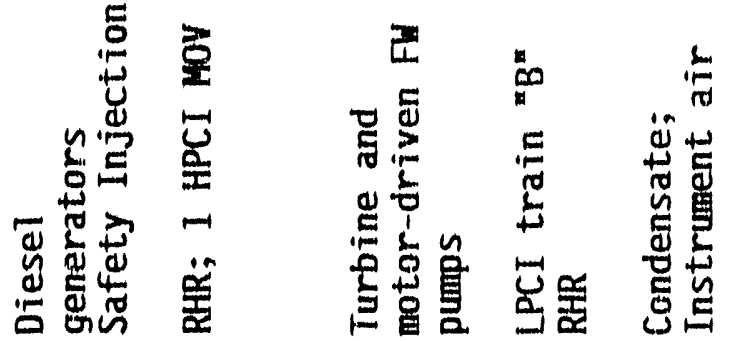

$\prod_{1}^{*}$

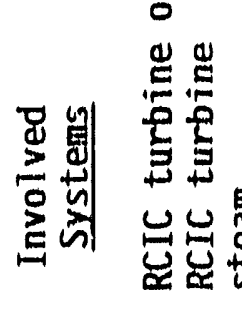

5

E

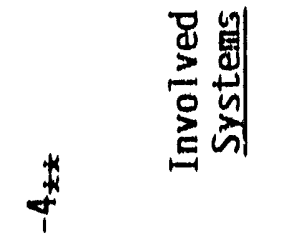

若

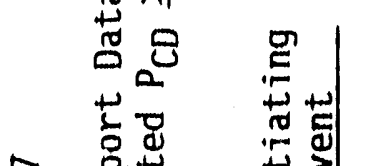

$T>0$

的空睨

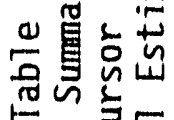

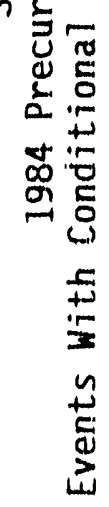

sै

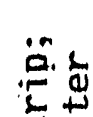

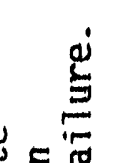

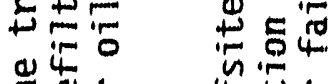

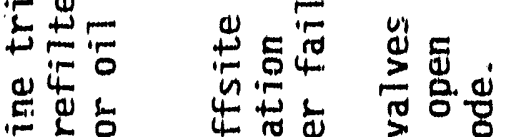

员过 出出

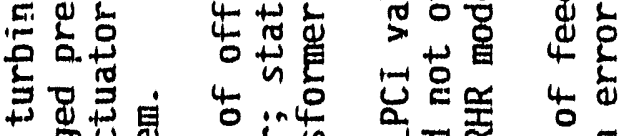

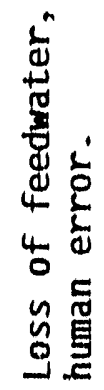

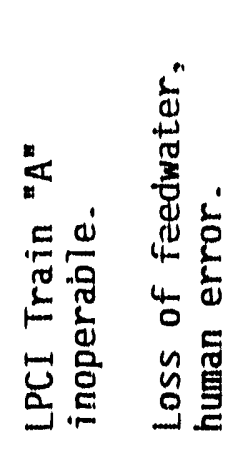

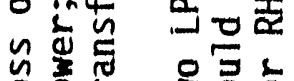

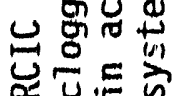

号就

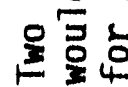

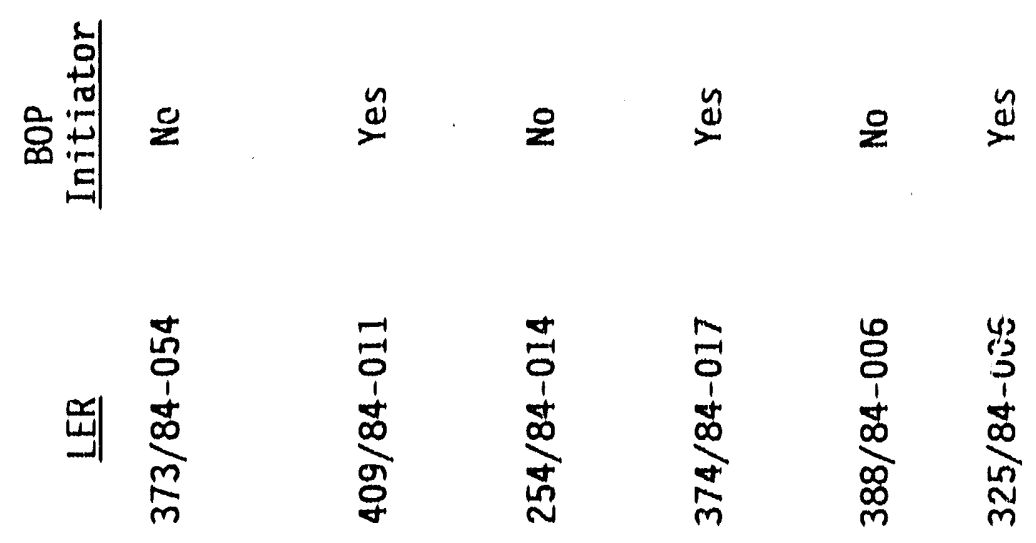

氬

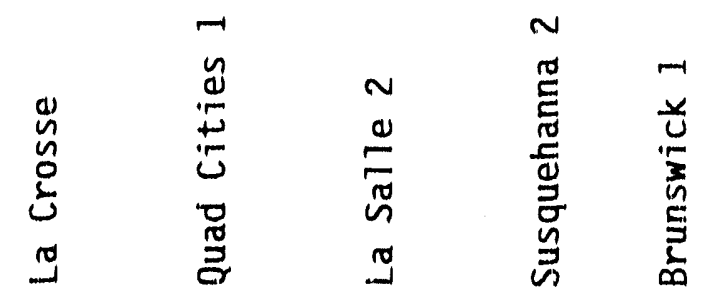

$-$

$\dot{m}$ 


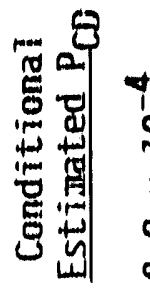

$y_{1}^{\prime}$
0
$n$
$x$
0
$n$

$i_{i=1}^{+1} \quad i_{m=1}^{+1}$

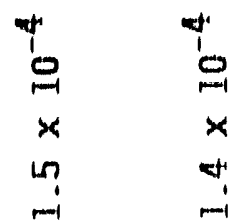

葛

ت్త્⿹

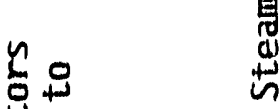

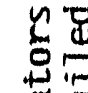

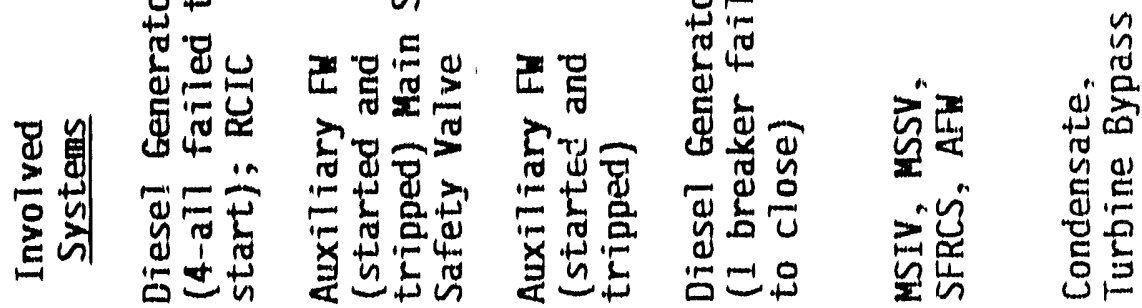

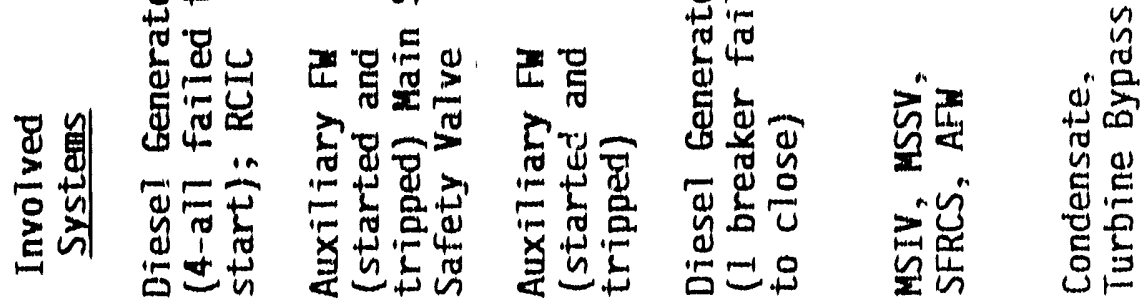

$\stackrel{4}{i}$

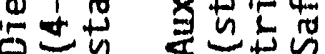

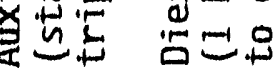

in

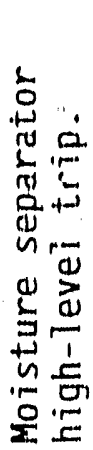

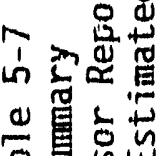

赵

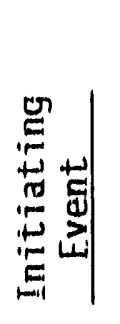

4.40.

4. ०ै को

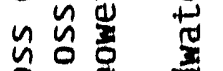

0

t。

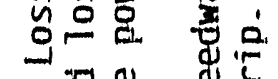

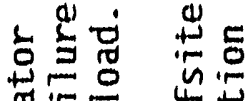

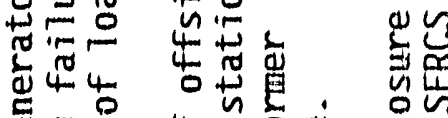

政

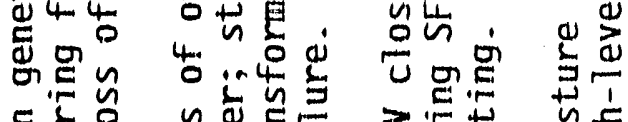

$=$ 등

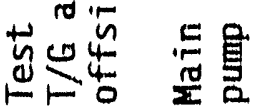

的密

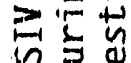

乐定

至管

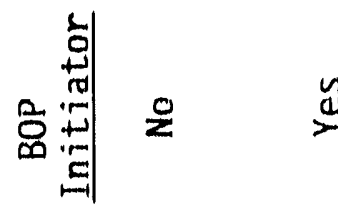

¿

$\stackrel{y}{2}$

$\stackrel{4}{2}$

$\stackrel{4}{ \pm}$

苞

兽

告

峁

䓠

步

点

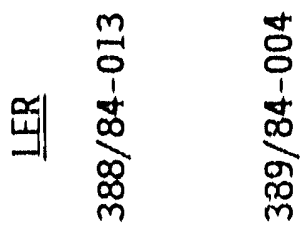

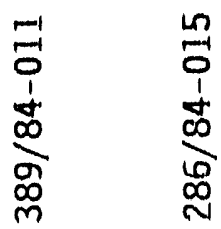

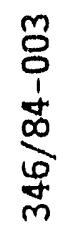

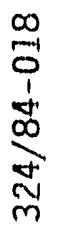

苟 究

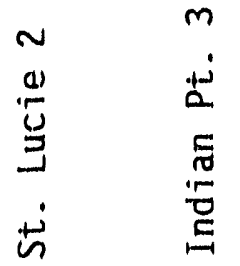

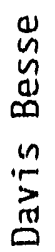

N

亗

范

का

$-i$

$\stackrel{\sim}{n}$

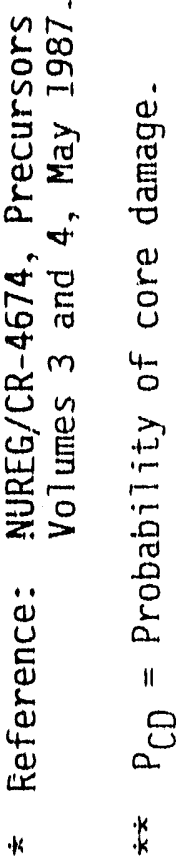




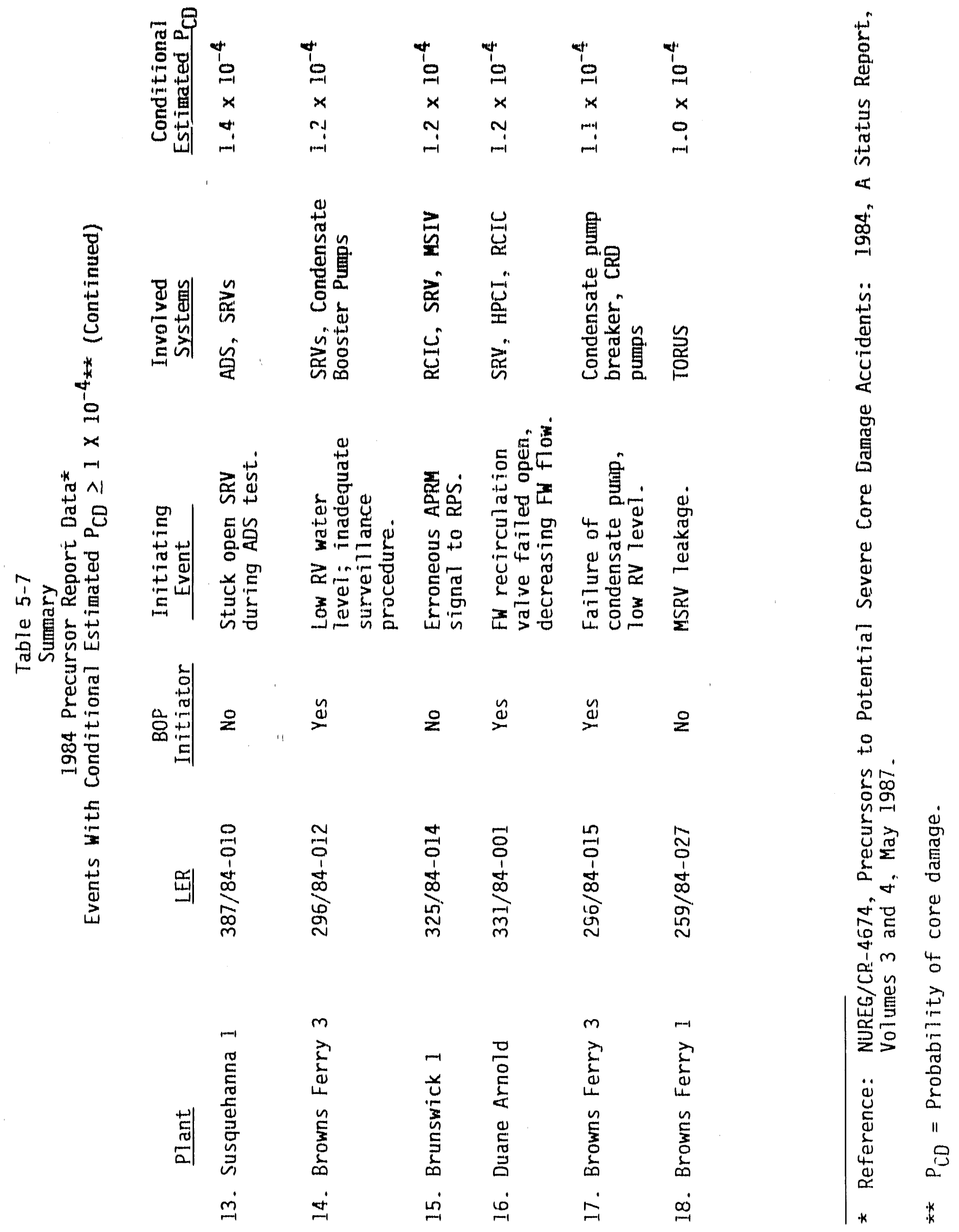


During 1985, approxtmately 3000 LERs were prepared by litcensees to report operations events in accordance with NRC reporting requitrements, of these 3000 events, approximately 1400 were selected for detalled revtew, and 63 of these were judged to meet the definttion of accident precursor events. After inserting these events into the approprlate places of accident sequence event trees and quantifying the sequences, 11 were estimated to have an assoctated condittonal probability of severe core damage $\geq 1 \times 10^{-4}$. Information on these 11 precursor events is provided in Table 5-8.

Nine of the 11 precursor events with a comparatively high probability of core damage had BOP initiators. These are also identified in Table 5-8 and consist of seven feedwater/condensate system degradation, one auxiltary transformer degradation, and one turbine pressure regulator fatlure. Only two of the 11 precursor events with a comparativaly high probability of core damage did not have BOP initiators.

During 1986, approximately 2900 LERs were prepared by licensees to report operations events in accordance with NRC reporting requilrements. Of these events, 1320 were selected for detalled revlew, resulting in 34 that were judged to meet the definttion of accident precursor events. After inserting these events thto accident sequence event trees and quantifying the sequences, six events were estimated to have an assoctated conditional probability of severe core damage $\geq 1 \times 10^{-4}$. Information on these six precursor events is provided in Table 5.9.

Three of the 6 precursor events with a comparatively high probability of core damage had BOP inttiators. These involved (1) loss of pressure in the turbine governor ofl system, (2) fuse-related problems in an electrical bus control ctrcult, and (3) a faulted controller for condenser steam dump valves.

\section{Summary}

For the 3-year pertod 1984 through 1986, 145 precursor events were identifted from LERs, and 35 of these precursors had estimated conditional probabilities of severe core damage $\geq 1 \times 10^{-4}$. Twenty-three of these 35 more significant precursor events (66 percent) involved BOP initiators. Thus, the fraction of BOP initiation of the more significant precursor 


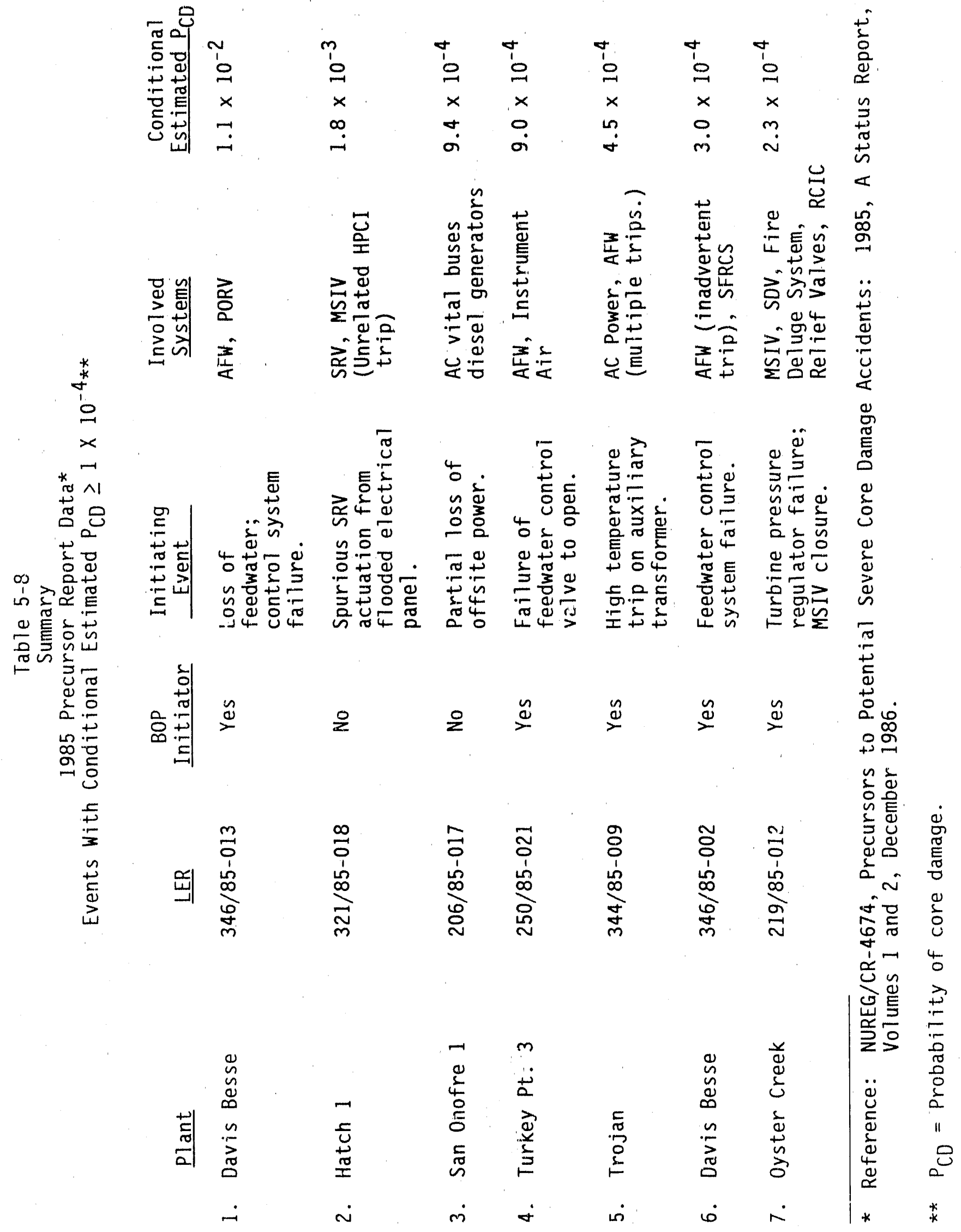




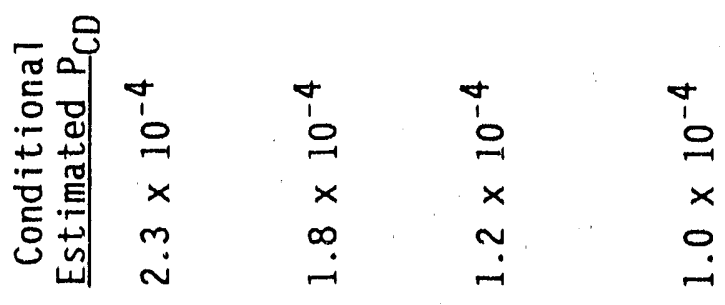

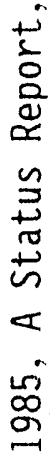

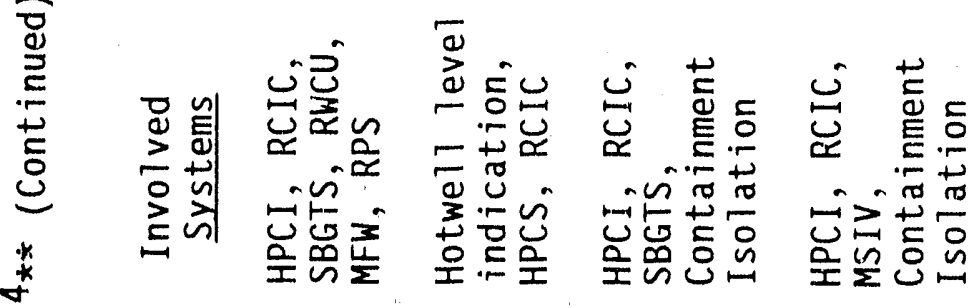

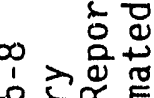

ه 茞.

定些战

$*$

†

$+2$

으

$x$

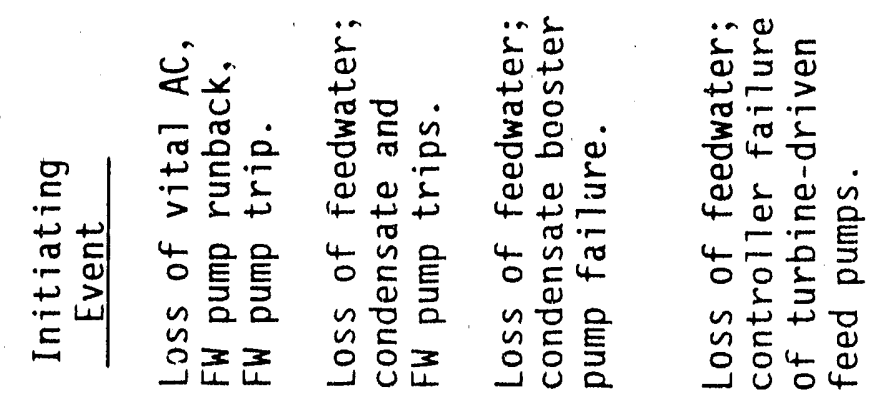

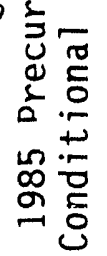

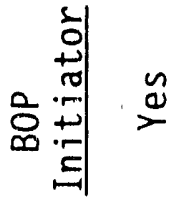

$\stackrel{\mathscr{a}}{2}$

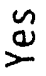

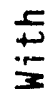

$\stackrel{n}{\stackrel{n}{ \pm}}$

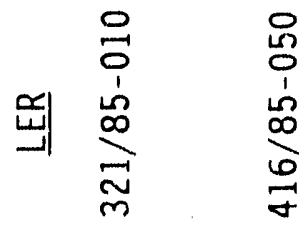

0
n
1
1
$\infty$
0
0
0
$m$

0
0
1
$\infty$
0

$\sim$

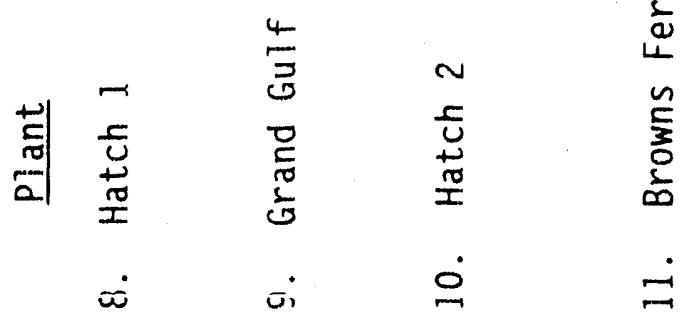




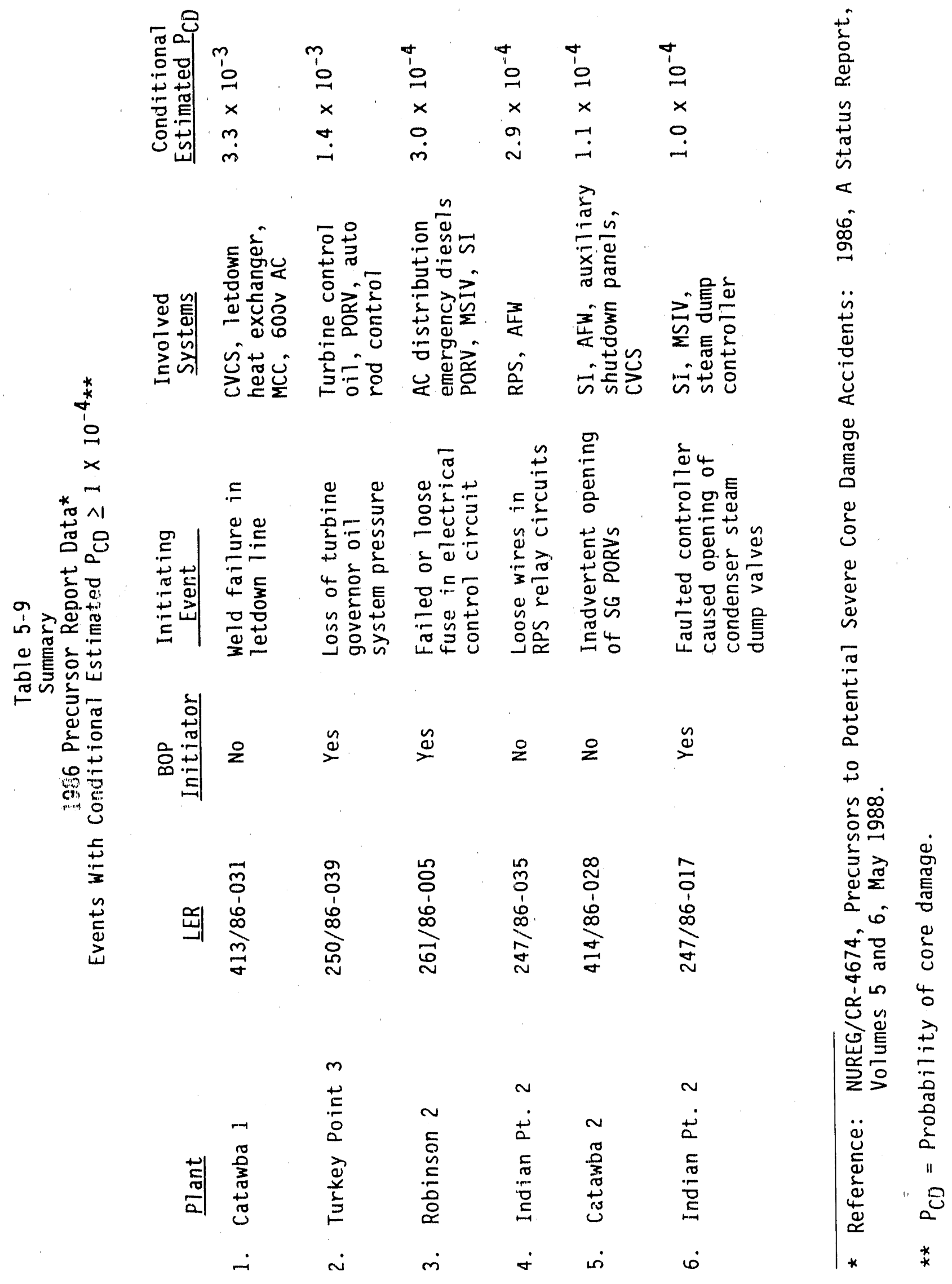


events is about the same as the fraction of BOP initiation of reactor trips in genera1. A summary of the BOP influence on precursor events for the years 1984 through 1986 is given in Table 5-10.

\subsection{Summary of Risk Implications}

The results of the delta risk analysis (Section 5.1) and the evaluation of BOP-related precursor events (Section 5.2) both show that the raliability of BOP systems can have a significant impact on the risk profiles of nuclear power plants. For BWRs, in particular, plant core melt frequency appears to be highly sensitive to the frequency of BOP-related transients. Using the study data for "poor" BCP performance BWRs, the delt.a risk analysis yielded core melt frequencies that were 2 to 4 times greater than the frequencies obtained using the data for the "good" BOP performance BWRs. The corresponding differences for PWRs were comparatively smal1, ranging from a factor of 1.1 to a factor of 1.3 .

Twelve of the 23 precursor events that were considered to be BOP-related and had a high probability of resulting in core damage occurred at BWRs. This is a disproportionate number of such events at BWRs, since approximately two-thirds of all operating U.S. reactors are PWRs. This finding supports the conclusion that BOP-related events are more important, from a risk perspective, at BWRs.

The overail impact of BOP system performance is greater than shown by the delta risk analysis for both BWRs and PWRs. Each of the PRAs used in the analysis included transient initiators with relatively low frequencies that can be considered BOP-related but did not appear in the study data base for the "good" and "poor" BOP performance plants. Therefore the risk associated with those types of events is not reflected in the delta risk calculations. Howe:er, if those types of events are included in the BOP contribution to core melt frequency, the contribution of BOP-related transients ranges from 14 percent to approximately 50 percent for PWRs, and from 36 percent to 59 percent for BWRs. 
Table 5-10

Summary of BOP Influence on Precursor Events, 1984-1986

\section{Precursor events designated}

48 events in 1984, out of approximately 2400 LERs

63 events in 1985, out of approximately 3000 LERs

34 events in 1986, out of approximately 2900 LERs

\section{4 precursor events}

18 of 48 events had estimated conditional $P_{C D} \geq 1 \times 10^{-4}$

11 of 18 events had BOP initiators

5 feedwater/condensate system degradation

2 station transformer failure, LOOP

1 main generator bearing failure

1 MSIV spurious closure

1 moisture separator high-level trip

1 surveillance procedure inadequacy

7 of 18 events did not have BOP initiators

\section{5 precursor events}

11 of 63 events had estimated conditional $P_{C D} \geq 1 \times 10^{-4}$

9 of 11 events had BOP initiators

7 feedwater/condensate system degradation

1 auxiliary transformer degradation

1 turbine pressure regulator failure

2 of 11 events did not have BOP initiators

\section{6 precursor events}

6 of 34 events had estimated conditional $P_{C D} \geq 1 \times 10^{-4}$

3 of 6 events had BOP initiators

1 loss of turbine governor oil system pressure

1 faulted or loose fuse in an electrical bus control circuit

1 faulted controller for condenser steam dump valves

3 of 6 events did not have BOP initiators

For 1984 through 1986

23 of 35 "High P $P_{C D}$ " events (66\%) had BOP initiators 


\section{References}

1. "Connecticut Yankee Probabilistic Safety Study," Northeast Utilities Service Company, Report No. NUSC0-149, February 1986.

2. "Probabilisilidisk Assessment: Limerick Generating Station," Philadelphia tilectric Company, March 1981.

3. NUREG/CR-3028, "A Review of the Limerick Generating Station Probabilistic Risk Assessment," Brookhaven National Laboratory, February 1983.

4. "Millstone Unit 1 Probabilistic Safety Study," Northeast Utilities Service Company, Report No. NUSCO-147, July 1985.

5. NUREG/CR-4142, "A Review of the Millstone 3 Probabilistic Safety Study," Lawrence Livermore National Laboratory, Apri1 1986.

6. "Oconee PRA: A Probabilistic Risk Assessment of Oconee Unit 3," Duke Power Company and the Electric Power Research Institute, Report No. NASC/60, June 1984.

7. NUREG/CR-4674, "Precursors to Potential Severe Core Damage Accidents: 1985, A Status Report," Volumes 1 and 2, December 1986.

8. NUREG/CR-4674, "Precursors to Potential Severe Core Damage Accidents: 1984, A Status Report," Volumes 3 and 4, May 1987.

9. NUREG/CR-4674, "Precursors to Potential Severe Core Damage Accidents: 1986, A Status Report," Volumes 5 and 6, May 1988. 


\section{FINDINGS AND RECOMMENDATIONS}

The major finding of this study was the dramatic reduction in BOP-related trips at commercial nuclear power plants over the 5-year study period from January 1, 1984 through December 31, 1988. This improved performance reduces the urgency of regulatory action to address BOP-related safety concerns. However, regulatory actions can be taken to (1) address the problems of licensees whose BOP trip performance is substantially less favorable than the industry average, and (2) maintain or further improve the performance levels achieved toward the end of the study period.

\subsection{Findings}

1. For the 76 mature nuclear units (OL before January 1, 1983) in the study data base, the average number of BOP trips per unit was reduced from 4.4 per critical year in 1984 to 2.4 per critical year in 1988.

The average mature unit over the 5-year period experienced 3.8 BOP trips per critical year. The corresponding value for the bestperforming unit in the data base was 0.2 BOP trips per critical year; the worst-performing unit experienced 11.2 BOP trips per critical year.

2. On a calendar year basis, for the 76 mature nuclear units in the study data base, the average number of BOP trips per unit was reduced from 2.8 per calendar year in 1984 to 1.6 per calendar year in 1988 .

The average mature unit over the 5 -year period experienced 2.3 BOP trips per calendar year. The best-performing unit experienced 1 BOP trip in 5 years; the worst-performing unit experienced 34 BOP trips in 5 years.

3. Nearly 30 percent of the BOP-related trips resulted from multiple-cause events.

This is a surprisingly large fraction of multiple-cause BOP trip events. Although there is some "softness" in the data, it is clear that multiple-cause events are more prevalent than previously assumed by many observers, and this finding has implications for statistical 
and risk assessment analysts. Most of the multiple-cause trips were not from coincident independent fallures or common.cause events, but rather from pre-existing conditions (e.g., degraded operability states of various systems or components) that were revealed when a related system or component was actuated.

4. Approximately 70 percent of the BOP-related trips resulted from a single event.

A single component failure was the causative mechanism in 49 percent of these single-cause trips, and a single human action accounted for approximately 34 percent. The balance of the single-cause events were of design, procedures or environmental origin, with a few classified as spurtous or unknown.

5. Considering BOP trips resulting from both single and multiple causes, nearly four out of every five events contributing to BOP trips were either component/equipment failures (47 percent) or human actions ( 31 percent).

Clearly the two most dominant general contributors to BOP trip causation are componerit/equipment failures and human actions. The value cited for human actions does not include design or procedural inadequacies, which were categorized separately. It follows from this finding that, in order to be successful, programs directed at achieving reductions in BOP-related trip frequencies w111 need to contain both a technical element (component, system or functional reliability improvement) and a human performance element (a reduction in human errors in operations, maintenance and surveillance).

6. NSSS Owners Groups with aggressive trip reduction programs are apparently achieving results in the form of reduced frequencies of BOPrelated trips.

Table 3-2, which shows annual average BOP trips per unit per calendar year by NSSS vendor, suggests that: 

Program (TRAP) began to show results in 1985;

the Babcock and Wilcox Owners Group's Safety and Performance Improvement Program (SPIP) began to show results in 1986; and

- the General Electric Owners Group's Scram Frequency Reduction Program and the Combustion Engineering Owners Group's Scram Reduction Program did not begin to show results until 1988.

7. At the system level, BOP trip causation was dominater y the condensate/feedwater system ( 40 percent of total trips) and the turbine/generator system (30 percent of total trips).

The degree of dominance of the two major contributors to BOP trip causation, the condensate/feedwater system and the turbine/generator system, was significant. The next largest contributor, AC power systems, contributed only 12 percent. Proceeding down the 1ist, main steam systems contributed 6.4 percent, air systems about 3 percent, and the other major systems contributed 2 percent or less (e.g., instrumentation and control systems, circulating water systems, etc.).

8. At the subsystem leve1, BOP trip causation was dominated by the feedwater control subsystem (61 percent of feedwater-related trips; 25 percent of total trips) and the turbine/generator instrumentation and control subsystem (60 percent of turbine/generator related trips; 18 percent of total trips).

Taken together, feedwater control and turbine/generator I\&C problems caused more than 40 percent of the total BOP trips. Many of the feedwater control problems were at low power levels, often associated with manual feedwater control or the transition from manual to automatic feetwater control. The turbine/generator I\&C problems centered primarily on the electro-hydraulic control (EHC) system for the turbine. 
9. At the component level, excluding the human "component," BOP trip causation was not dominated by any single component or small group of components.

A majority of the BOP-related trips was caused by aggregated sma11 contributions from a very large number of different components. Pumps, valves and circult cards were the largest contributors in most cases, but none of these contributed a large fraction of the total. This complicates the task of achleving further improvements by requiring that a component reliabllity improvement program be very broad-based, and not focused on a few major contributors.

10. Nearly all the units with the best BOP trip performance (fewest BOPrelated trips) have motor-driven feedwater pumps; nearly all the units with the poorest BOp trip performance (highest numbers of BOP trips) have turbine-driven feedwater pumps.

Feedwater systems with motor-driven feedwater pumps perform more reliably than systems with turbine-driven feedwater pumps. In addition, plants with excess feedwater capacity perform only marginally better than plants without excess feedwater capacity. Apparentiy, the combination of feedwater control characteristics and reactor trip setpoints on steam generator level do not usually allow operators enough time to utilize excess feedwater pump capacity to avoid a trip when a feedwater pump is lost.

11. From a risk perspective, BOP-related transients contribute significantiy more, on a fractional basis, to the estimated core melt frequencies of BWRs than they do to PWRs.

Core melt frequency estimates in BWR PRAs are more affected by changes in BOP transient frequencies than are the corresponding estimates for PWR PRAs. Based on a limited number of PRA comparisons, the incremental core melt frequencies between "good" and "poor" performers in terms of BOP-related trips were factors of 2 to 4 for BWPS and factors of 1.1 to 1.3 for PWRs. 
12. BOp-related transients are the initiating events for approximately twom thirds of the more significant accident precursor events.

The NRC's Acctdent Sequence Precursor program esttmates the condttional probability of severe core damage assoctated with the occurrence of operating events. For the years 1984 through 1986, 35 operating events were calculated to have estimated conditional probabilitites of severe core damage greater than or equal to $1 \times 10^{-4}$. Two-thtrds of these events (23 events) had BOP inttlators. This two-thirds fraction ts approximately the same as the BOP-related contribution to total unplanned reactor trips.

\subsection{Recommendations}

The dramatic reduction in the number of BOP-related reactor trips at commerctal nuclear power plants over the 5-year pertod ending December 31 , 1988 , reduces the urgency of regulatory actions directed at BOP performance improvements. However, regulatory actions can and should be taken to (1) maintain the trend toward decreasing numbers of BOP-related reactor trips among NRC 1icensees, and (2) address the problems of 1tcensees whose performance is substantially less favorable than the industry average.

\subsubsection{General Recommendations}

1. Communicate to licensees and applicants, in the form of an informational generic letter, the results of recent studies on BOP. related trips and overall scram reduction experience.

This generic letter should point out where improvements in trip reduction can be made while formally acknowledging the recent improved performance of most ifcensees. Transmitted with this informational generic letter should be a copy of this BOP-specific study and a copy of Volume 5 of NUREG-1275, "Operating Experience Feedback Report Progress in Scram Reduction, "March 1989. This generic letter, with the attached reports, will provide 1 icensees with a basis for making decisions on their plant-speciftc programs for minimizing unplanned reactor trips. 
2. Identify, monitor and communtcate with licensees who are not achileving an acceptably low frequency of BOP-related trip events at their factlities.

For the purposes of identlfying 1 icensees in need of increased regulatory attention, an "acceptably low frequency of BOP-related trip events" could be defined as the 5-year (1984-1988) industry average, 3.8 BOp trips per critical year, plus one standard devtation (approximately 2.2) or about 6 BOp trips per crittcal year. It is recommended that 1 icensees who do nut achieve a frequency less than about 6 BOP trips per critical year, in any given year, be candidates for increased regulatory attention to BOP performance. Actions could include consultations with the 1icensee on how the problem is being addressed, and spectal inspections on BOP systems reliability, the adequacy of root cause analys is of reactor trip events, and performance trends.

3. NRC should work with INPO, the Owners Groups, and EPRI to assist licensees in achieving and maintaining an acceptably low frequency of BOP-related trip events at their nuclear plants.

Because of the limited reach of NRC's regulations into the BOP systems, improvements in BOP performance will (and have) come largely through industry initiatives on the basis of economics and reliability. However, based on the findings of this study, NRC could stimulate improvements in BOP systems performance by working with industry in the followirig areas:

a. Encourage a steadily increasing level of industry performance of root cause analyses of reactor trips.

b. Encourage Owners Groups and individual utilities to continue their aggressive pursult of trip reduction programs.

c. Process requests for BOP-related changes to Technical Speciftcations in a timely manner. 
d. Investigate why turbine driven main feedwater pumps do not perform as reltably as motor-drtven main feedwater pumps.

e. Investigate how to make better use of excess feedwater pumping capacity (where it exists) to reduce the frequency of feedwater-related reactor trips.

4. NRC should formally incorporate BOp trip avoldance expertence into the Systematic Assessment of Litcensee Performanco (SALP) process, e.g.. as an element in the Safety Assessment/quallty Vertfication category.

This action would increase the visibllity level of BOP performance trends among 1 icensee management, resident inspectors, NRC Project Managers, and NRC sentor manayement. This action could be coordinated with programs on performance indicators, maintenance improvements and routine inspections.

\subsubsection{Spectfic Recommendations}

1. Establish a responsibility center within NRC to specifically monitor and evaluate BOP-related reactor trip experience.

The functions of this responsibility center would be to identify "outliers" in terms of BOP trip expertence; compare 1tcensee and overall industry performance with goals established by NRC and by industry; compare industry performance with that in foreign countries; and perlodically report to the NRC management on the state of BOP systems performance in the industry.

2. NRC should expand the role of BOP systems in ongoing NRC activities, specifically in the areas of inspections, maintenance policy, Technical Specifications improvements, human factors and training, severe accident policy/IPEs, the Accident Sequence Precursor program, and advanced reactors/standardization, as discussed below. 
a. Inspections

NRC should assure that Resident Inspectors perfodically evaluate the BOP trip expertence of thetr untts. The spectal BOP inspection program should be reinstituted for plants with particularly poor BOP trip performance histortes.

\section{b. Maintenance Pollcy/Rulemaking}

Draft Regulatory Gutde DG-1001, "Maintenance Programs for Nuclear Power Plants," should suggest a goal of less than or equal to one BOP trip per calendar year on the same basts (e.g., capactty factor greater than 25 percent) as the INPO 1990 goal for total reactor trips of 1.5 per calendar year. NRC should evaluate BOP trip performance as a function of whether a 11 icensee's matntenance program provides the same level of attention to BOP systems as is given to safety systems. Spectfic emphasts should be given to main feedwater control systems and turbine electro-hydraulic control systems.

\section{c. Technical Spectftcations Improvements}

NRC should evaiuate, in coordination with 1tcensees, BOP-related safety limits, limiting conditions for operation, survelliance frequenctes and trip setpoints for their effects on BOP trip causation. Spectfic emphasis should be given to steam generator level trip setpoints, steam flow/feed flow mismatch trips, and the frequency of turbine control valve testing.

\section{d. Human Factors and Training}

The NRC programs on human factors and training should include an element on avolding BOP trips caused by operations and matntenance errors (and to a lesser degree survetllance testing errors) by both 1 icensed and unlicensed operations persunnel. 
e. Severe Accident Policy/IPEs

Because of the influence of BOP system failures on core melt frequency estimates, the NRC review of IPEs should compare the BOP initiating event frequencies used in the analyses with the experience values reported herein.

\section{f. Accident Sequence Precursor Program}

NRC should build on the evaluation reported herein and perform an in-depth evaluation of the influence of BOP system failures or degradations on the higher-ranking accident precursor events.

\section{g. Advanced Reactors and Standardization}

With regard to BOP considerations, the NRC reviews of advanced reactors and standardized designs should focus on improvements in the main feedwater control and turbine electro-hydraulic control systems. Further, NRC should encourage the use of motor-driven (rather than turbine-driven) main feedwater pumps.

3. NRC should expand the evaluation of the risk implications of BOP events to additional PRA studies to test the validity of the risk-related findings made herein.

Based on a comparison with 6 PRA studies ( 3 PWR, 3 BWR, two on the same BWR) this study concluded that the incremental difference in core melt frequency estimates between "yood" and "poor" BOP performers was a factor of 2 to 4 for BWRs and a factor of 1.1 to 1.3 for PWRs. NRC should expand this evaluation to more PRA studies to test the validity of these estimates.

4. NRC should investigate the impl scations of the relatively large numbers of multiple-cause events for statistical and risk analyses.

The methods used in statistical or risk analyses for estimating commoncause or dependent-failure events may not adequately account for the types of multiple failures found in this study for magnitudes as large 
as 20 to 30 percent of total failures. NRC should examine the implications of these higher frequencies of multiple-cause events, which are (in general) reither dependent failures nor common-cause events. Also, the trade-offs associated with additional component testing or more frequent testing would uncover more undetected degradations, but it could also result in more inadvertent trips associated with the testing. 


\section{APPENDIX A}

Sample Entries from the BOP Data Base 
Form: 88

Plant Name: Dresden 2

Event ID: $237 / 85-035$

Event Date: 09/29/85

Power Leve 1: $\quad 00 \%$

Trip Type: Auto

BOP System: Turbine Generator

BOP Subsystem: Steam Relief

BOP Component: Bellows

Cause 1: Design Related

Cause 2: Component Failure: Bellows

Event Description: Steam flow through seal steam relief valves may have damaged the bellows (expansion joint) during normal system operation. The damaged bellows resulted in a low condenser vacuum causing a turbine trip and a subsequent reactor scram.

$\star * \star$ BOP RELATED EVENT $* * \star$

$===============$

Form: $\quad 229$

Plant Name: Quad Cities 1

Event ID: $254 / 86-030$

Power Level: $\quad 90 \%$

Event Date: 10/16/86

Trip Type: Auto

BOP System: Turbine Generator

BOP Subsystem: $T / G$ Instrumentation \& Control

BOP Component: Human

Cause 1: Human Related: Maintenance

Event Description: While testing the electro-hydraulic control system, test personnel generated a turbine bypass valve open signal. Subsequent excess steam flow caused MSIV closure and a reactor trip on MSIV position. 
Form:

230

Plant Name: Quad Cities 1

Event ID: $254 / 86-038$

Power Level: $\quad 15 \%$

Event Date: 12/09/86

Trip Type: Auto

BOP System: Turbine Generator

BOP Subsystem: Condenser

BOP Component: Unknown

Cause 1: Unknown

Cause 2: Human Related: Operations

Event Description: Adequate condenser vacuum could not be maintained during startup. Personnel attempted to continue startup hoping the condition would improve. It didn't and the p'lant tripped. The reason for failure to maintain condenser vacuum was not given.

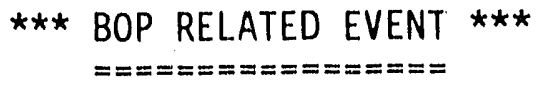

Form: 231

Plant Name: Quad Cities 1
Event ID: $254 / 87-005$
Event Date: $03 / 17 / 87$
Power Level: $\quad 92 \%$
Trip Type: Auto

BOP System: Main Steam

BOP Component: Valve

Cause 1: Component Failure: Valve

Cause 2: Human Related: Maintenance

Event Description: Turbine stop valve closure caused a turbine trip and a reactor trip. The stop valve closure was caused by a high level in the moisture separators which in turn was partially due to a stuck open level control valve. Operator attempts to repair the valve contributed to this event because other level control valves could not properly handle sufficient flow. 
Form:

232

Plant Name: Palisades

Event ID: $255 / 84-015$

Power Leve 1: $\quad 48 \%$

Event Date: 08/04/84

Trip Type: Auto

BOP System: Turbine Generator

BOP Subsystem: $T / G$ Instrumentation \& Control

BOP Component: Human

Cause 1: Human Related: Mairitenance

Event Description: EHC system repairs were not properly performed. The resulting vibration in the EHC system caused a turbine trip and reactor trip.

$\star \star \star$ BOP RELATED EVENT $* \star \star$

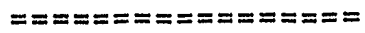

Form:

233

Plant Name: Palisades

Event ID: $255 / 85-010$

Power Level: $\quad 98 \%$

Event Date: $08 / 11 / 85$

Trip Type: Auto

BOP System: Turbine Generator

BOP Subsystem: $T / G$ Instrumentation \& Control

BOP Component: Transformer

Cause 1: Component Failure: Transformer

Event Description: A motor operated auto transformer operated erratically during a voltage adjustment, The erratic performance caused a loss of generator load and a turbine/reactor trip. 
Form:

276

Plant Name: Robinson 2

Event ID: $261 / 87-020$

Power Leve 1: $\quad 100 \%$

Event Date: $07 / 10 / 87$

Trip Type: Auto

BOP system: DC Power

BOP Component: Wire

Cause 1: Component Failure: Wire

Event Description: The plant tripped on July 10, 1987 due to a Feedwater regulator valve fallure caused by an electrical short in the $D C$ wire to one of the two safeguard solenoids for the valve operator. The solenoid failed due to entrapped water in the solenoid condulet. The Feedwater regulator valve closure resulted in Steam/Feedwater flow mismatch coincident with a low SG level.

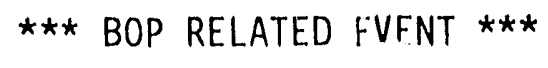

Form: $\quad 276$

Plant Name: Robinson 2

Event ID: $261 / 87-020$

Power Level: $\quad 72 \%$

Event Date: $07 / 16 / 87$

Trip Type: Auto

BOP System: Feedwater

BOP Subsystem: Feedwater Control

BOP Component: Feedwater regulator valve

Cause 1: Component Failure: Feed reg valve

Event Description: On July 16, 1987, the reactor tripped on 10w SG level coincident with Steam/Feedwater flow mismatch caused by the failure of the same Feedwater regulator valve as described in the $7 / 10 / 87$ event. This time, the valve failure was caused by the impaired function of the valve positioner. 
Form: 278

Plant Name: Robinson 2

Event ID: 261/88-001

Power Leve 1: $\quad 66 \%$

Event Date: $01 / 19 / 88$

Trip Type: Auto

BOP System: Turbine Generator

BOP Component: Regulator valve

Cause 1: Surveillance

Cause 2: Component Failure: Regulator valve

Event Description: Normal surveillance testing of the turbine was conducted. Due to wear and tear, an air operated pressure regulator valve did not function properly and was unable to withstari the back pressure after the turbine was returned to service. A pressure loss in the turbine caused the turbine to trip, which subsequently caused a reactor trip.

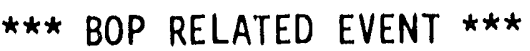

$-\therefore====\approx= \pm== \pm==2$

Form:

280

Plant Name: Monticello

Event ID: $263 / 85-008$

Power Level: $\quad 100 \%$

Event Date: $04 / 11 / 85$

Trip Type: Auto

BOP System: AC Power

BOP Subsystem: High Voltage Offsite

BOP Component: Transformer

Cause 1: Human Related: Maintenance

Event Description: A phase fault occurred while i transformer was being restored from maintenance. The fault was caused by a "non-plant" worker who forgot to remove grounding cable after the completion of the work. Because the trippirig contro? system was not yet in service, the turbine control system initiated reactor scram.

$$
A-5
$$


Form:

281

Plant Name: Monticello

Event ID: $263 / 85-010$

Power Level: $\quad 100 \%$

Event Date: $06 / 12 / 85$

Trip Type: Auto

BOP System: Main Steam

BOP Component: Human

Cause 1: Human Related: Survefllance

Event Description: During survelllance testing of the main steam low pressure instrumentation, a human error contrary to the approved procedure was committed leading to MSIV closure, which then lead to a reactor trip. The technician failed to properly valve in and out the appropriate pressure switch channels.

$\star * *$ BOP RELATED EVENT ***

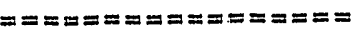

Form:

368

Plant Name: Salem 1

Event ID: $272 / 87-007$

Event Date: 06/02/87

Power Level: $\quad 100 \%$

Trip Type: Auto

BOP System: Turbine Generator

BOP Subsystem: $T / G$ Instrumentation \& Control

Cause 1: Environment: Lightning

Event Description: A turbine/reactor trip occured when lightning struck in the vicinity of the DEANS switching station causing a momentary loss of the 500KV transmission line and actuating the SALEM/DEANS "cross trip scheme" for "generator protection". This X-trip was established to prevent potential generator instability at Salem 1. 
Form:

370

Plant Name: Salem 1

Event ID: $272 / 88-009$

Power Level: $\quad 100 \%$

Event Date: $03 / 30 / 88$

Trip Type: Manual

BOP System: Turbine Generator

BOP Subsystem: $T / G$ Instrumentation \& Control

BOP Component: Indicator

Cause 1: Component Fallure: Indicator

Cause 2: Human Related: Operations

Event Description: During full power operation, EHC pump 12 tripped and the standby EHC pump 11 failed to auto start. With both pumps failed, the control oil system pressure decreased and the turbine governor valves drifted closed. The reactor was then manually tripped due to increasing $T$ avg. Prior to the event, the EHC oll had been leaking, and constant refill was required. However, the level indicator malfunctionned, and constantly indicated normal or full level, although oil level was actually at the pump low level lockout setpoint. Thus the lack of communication and level instrumentation failure were the root causes of this event.

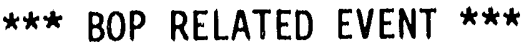

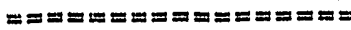

Form: $\quad 371$

Plant Name: Diablo Canyon 1

Event ID: $275 / 84-015$

Power Leve 1: $\quad 2 \%$

Event Date: $05 / 08 / 84$

Trip Type: Auto

BOP System: Main Steam

BOP Subsystem: Steam Relief

BOP Component: Circuit card

Cause 1: Component Fallure: Circuit card

Event Description: A failed pressure control module in the steam dump control system allowed several $40 \%$ steam dump valves to open, initiating a high steam flow coincident with LO-LO Tavg that tripped the reactor. This event occurred during startup. 
Form:

374

Plant Name: Diablo Canyon 1

Event ID: $275 / 84-030$

Power Level: $\quad 21 \%$

Event Date: $11 / 24 / 84$

Trip Type: Auto

BOP System: Turbine Generator

BOP Subsystem: $T / G$ Instrumentation \& Control

BOP Component: Human

Cause 1: Human Related: Construction

Cause 2: Component Failure: Valve

Event Description: This event was caused by a loose wire in the turbirie control system, causing the system to malfunction. Additionally, the $40 \%$ condenser dump valves failed to open resulting in a turbine/reactor trip. The cause for the dump valve fallure to open was traced to the installation of controi wiring according to an incorrect drawing of the electrical connections.

\section{$\star * *$ BOP RELATED EVENT $* \star \star$}

Form: $\quad 471$

Plant Name: Prairie Is land 1

Event ID: $282 / 86-010$

Power Leve 1: $\quad 100 \%$

Event Date: $12 / 12 / 86$

Trip Type: Auto

BOP System: Turbine Generator

BOP Subsystem: $T / G$ Instrumentation \& Control

BOP Component: Human

Cause 1: Human Related: Maintenance

Event Description: During troubleshooting of the turbine EHC, a multichannel event triggered recorder was being connected to the EHC cabinet. Incorrect use of this device caused a turbine trip/reactor trip. 
Form:

475

Plant Name: Fort Calhoun 1

Event ID: $285 / 86-004$

Event Date: 08/01/86
Pcwer Leve 1: $\quad 085 \%$

Trip Type: Manual

BOP System: AC Power

BOP Subsystem: High Voltage

BOP Comporient: Bus duct

Cause 1: Component Failure: Bus duct

Cause 2: Component Fallure: Bus duct insulation

Event Description: An operator noticed smoke coming from the plant isolated phase bus duct. During the following controlled shutdown, the condition worsened (the smoke intensified). The operators manually scrammed the reactor at $85 \%$ power. The arcing of the bus duct was due to a breakdown of the insulation on the bus duct.

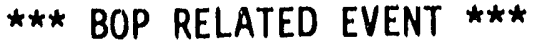

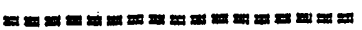

Form: $\quad 477$

Plant Name: Indian Point 3

Event ID: $286 / 84 / 005$

Power Level: $\quad 90 \%$

Event Date: $02 / 20 / 84$

Trip Type: Auto

BOP System: Feedwater

BOP Subsystem: Feedwater Control

BOP Component: Solenoid valve

Cause 1: Component Failure: Solenoid valve

Event Description: A Steam/Feedwater flow mismatch caused a reactor trip. The flow mismatch was caused by closure of a Feedwater regulator valve due to fallure of a trip solenoid. The solenoid failure was caused by water leakage into the solencid terminal box. 
Form:

893

Plant Name: Duane Arnold

Event ID: $331 / 86-01$ ?

Power Leve 1: $\quad 5 \%$

Event Date: 06/13/86

Trip Type: Manual

BOP System: Air

BOP Component: Air line

Cause 1: Component Failure: Air line

Cause 2: Environment: Contamination

Event Description: Dessicant material in instrument air flow lines caused a fluctuation in the position of Feedwater control valves, which caused a trip of Feedwater block valves. This led to a loss of Feedwater, which led to a manual reactor trip on low reactor water level.

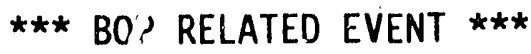

$=:=x============$

Form: $\quad 896$

Plant Name: Fitzpatrick

Event İ̀: $333 / 84-009$

Power Level: $\quad 67 \%$

Event Date: $03 / 22 / 84$

Trip Type: Auto

BOP System: Feedwater

BOP Component: Pump

Cause 1: Component Failure: Pump

Event Description: Fallure of a Feedwater pump bearing caused a loss of the Feedwater pump which led to a loss of Feedwater. This resulted in a reactor trip on low reactor water level. 
Form:

897

Plant Name: Fitzpatrick

Event ID: $333 / 84-010$

Power Level: $\quad 25 \%$

Event Date: $03 / 25 / 85$

Trip Type: Auto

BOP System: Feedwater

BOP Subsystem: Feedwater Control

BOP Component: Control oil

Cause 1: Component Failure: Control oil

Event Description: Control oil leakage resulted in a loss of Feedwater due to a Feedwater pump trip. This lead to a reactor trip on low reactor water level.

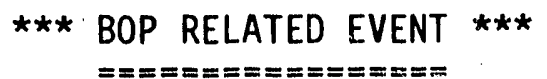

Form: $\quad 1074$

Plant Name: Limerick

Event ID: $352 / 87-048$

Event Date: 09/19/87

Power Leve 1: $\quad 090 \%$

Trip Type: Auto

BOP System: Turbine Generator

BOP Subsystem: $T / G$ Instrumentation \& Control

BOP Component: Weld

Cause 1: Human Related: Maintenance

Event Description: A weld failure resulted in low EHC oil pressure which caused a turbine trip and reactor trip. Review revealed an inadequate weld. 
Form: $\quad 1075$

Plant Name: Hope Creek 1

Event ID: $354 / 86-034$

Power Leve 1: $\quad 003 \%$

Event Date: $07 / 12 / 86$

Trip Type: Manual

BOP System: Main Steam

BOP Component: Pressure transmitter

Cause 1: Component Failure: Pressure transmitter

Cause 2: Component Failure: Pressure transmitter

Event Description: Two erroneous high steam flow signals caused an MSIV closure. Operators elected to shutdown the plant. Cause of the failure of the 2 pressure transmitters was not determined.

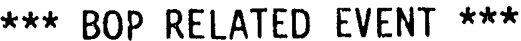

$==\mathbf{=}=\mathbf{=}=\mathbf{=}=\mathbf{=}=\mathbf{=}==$

Form: $\quad 1192$

Plant Name: Arkansas Nuclear One - 2

Event ID: $368 / 87-008$

Power Leve1: $\quad 100 \%$

Event Date: $11 / 14 / 87$

Trip Type: Auto

BOP System: Turbine Generator

BOP Si bsystem: $T / G$ Instrumentation \& Control

BOP Component: Human

Cause 1: Human Related: Maintenance

Event Description: Improper calibration settings in the turbine vibration trip system resulted in a spurious high vibration signal (in the turbine journal bearing vibration trip logic) that led to a turbine trip and a subsequent reactor trip. 
Form:

1196

Plant Name: McGuire 1

Event ID: $369 / 84-024$

Power Levei: $\quad 100 \%$

Event Date: $08 / 21 / 84$

Trip Type: Auto

BOP System: AC Power

BOP Subsystem: High Voltage

BOP Component: Computer

Caus a 1: Component Failure: Computer

Cause 2: Design Related

Event Description: After corrective maintenance, the restarted switchyard computer opened power circuit breakers, causing a reactor and turbine trip.

\section{$* \star \star$ BOP RELATED EVENT $* * *$}

Form: $\quad 1316$

Plant Name: Waterford 3

Event ID: $382 / 87-028$

Power Level: $\quad 90 \%$

Event Date: $12 / 11 / 87$

Trip Type: Auto

BOP System: Main Steam

BOP Component: Solenoid valve

Cause 1: Component Failure: Solenoid valve

Event Description: During MSIV testing, one MSIV went partially shut due to a failed solenoid valve. This resulted in a reactor trip. 
Form:

1317

Plant Name: Susquehanna 1

Event ID: $387 / 84-013$

Power Level: $\quad 74 \%$

Event Date: 03/03/84

Trip Type: Auto

BOP System: Turbine Generator

BOP Subsystem: Thrust Bearing Wear Detector

BOP Component: Thrust bearing wear detector

Cause 1: Spurious Signal

Event Description: During weekly preventive maintenance activities, the turbine tripped on a spurious trip of the TBWD pressure switches. The reactor tripped following the fast closure of the turbine control valves. The cause of the turbine trip was not determined and is considered to have been a spurious occurrence.

$\star \star \star$ BOP RELATED EVENT $* \star \star *$

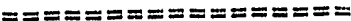

Form: $\quad 1764$

Plant Name: Clinton 1

Event ID: $461 / 87-060$

Event Date: $10 / 02 / 87$

Power Level: $\quad 90 \%$

Trip Type: Auto

BOP System: DC Power

BOP Component: Human

Cause 1: Human Related: Operations

Event Description: An operator incorrectly opened a crosstie breaker between 2 non-class 1E 125VDC distribution channels. The reactor tripped on a reactor high water level signal. 
Form:

1768

Plant Name: Wolf Creek 1

Event ID: $482 / 85-039$

Event Date: 06/06/85

Power Level: $\quad 006 \%$

Trip Type: Auto

BOP System: Feedwater

BOP Subsystem: Steam Relief

BOP Component: Human

Cause 1: Human Related: Surveillance

Event Description: Level oscillations caused by a steam dump control system test resulted in a low SG level and a subsequent reactor trip.

\section{$\star * *$ BOP RELATED EVENT ***

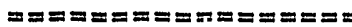

Form: $\quad 1851$

Plant Name: Palo Verde 1

Event ID: $528 / 86-020$

Event Date: 02/03/86

Power Level: $\quad 60 \%$

Trip Type: Auto

BOP System: Feedwater

BOP Subsystem: Feedwater Control

BOP Component: Circuit card

Cause 1: Component Failure: Circuit card

Event Description: A failed control board in the Feedwater control system resulted in a temporary inability of the operators to control Feedwater pump speed from the control room. Loss of manual Feedwater control led to a Low SG Level that subsequently tripped the reactor. 
APPENDIX B

BOP Trips per Calendar Year by Plant (Raw Data, 1984-1988) 
Table B.1

BOP Trips By Year - Babcock and Wilcox Units

$\underline{\text { UNII }}$

ARKANSAS NUCLEAR ONE 1

CRYSTAL RIVER 3

DAVIS BESSE

OCONEE 1

OCONEE 2

OCONEE 3

RANCHO SECO

TMI 1

MATURE UNITS

(OL BEFORE JAN 83)
$\mathrm{OL}$

DATE

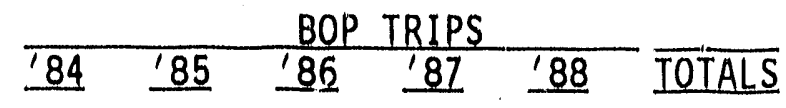

$\begin{array}{lllllll}\text { DEC } 74 & 3 & 8 & 1 & 2 & 0 & 14\end{array}$

$\begin{array}{lllllll}\text { DEC } 76 & 2 & 8 & 0 & 2 & 2 & 14\end{array}$

$\begin{array}{lllllll}\text { APR } 77 & 2 & 4 & 1 & 4 & 2 & 13\end{array}$

$\begin{array}{llllllll}\text { FEB } & 73 & 2 & 4 & 2 & 0 & 1 & 9\end{array}$

$\begin{array}{lllllll}\text { ОСТ } 73 & 0 & 3 & 3 & 2 & 1 & 9\end{array}$

JUL $74 \quad 3 \quad 2 \quad 2 \quad \begin{array}{llll}74 & 3 & 2 & 9\end{array}$

AUG $74 \quad 5 \quad 3 \quad-\quad-\quad 3 \quad 11$

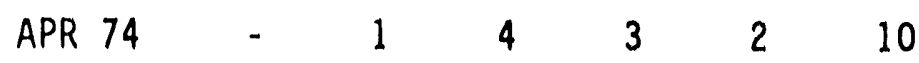

$\begin{array}{lllllll}\text { TOTALS } & 17 & 33 & 13 & 13 & 13 & 89\end{array}$

AVG

$\begin{array}{lllll}2.43 & 4.13 & 1.86 & 1.86 & 1.62\end{array}$ 
Table B.2

BOP Trips By Year - Combustion Engineering Units

UNIT

OL

DATE
184

5

41

6

JUL 74

AUG 76

MAY 73

JUN 73

AUG 75

OCT 72

DEC 84

DEC 85

JAN 88

$\begin{array}{lllllll}\text { SEP } 82 & 1 & 4 & 3 & 3 & 0 & 11\end{array}$

$\begin{array}{lllllll}\text { SEP } 83 & 3 & 2 & 3 & 2 & 0 & 10\end{array}$

$\begin{array}{lllllll}\text { MAR } 76 & 1 & 0 & 2 & 5 & 4 & 12\end{array}$

$\begin{array}{lllllll}\text { APR } 83 & 7 & 5 & 3 & 5 & 0 & 20\end{array}$

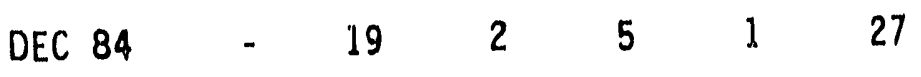

$\begin{array}{lllllll}\text { TOTALS } & 31 & 56 & 44 & 46 & 18 & 195\end{array}$

AVG

$$
\begin{array}{lllll}
2.33 & 2.78 & 2.67 & 3.33 & 1.33
\end{array}
$$

$A V G$

$$
\begin{array}{lllll}
5.00 & 7.75 & 4.00 & 3.20 & 1.00
\end{array}
$$

(9) MATURE PL.ANTS

(OL BEFORE JAN 83)

NEW PLANTS 
Table B.3

BOP Trips by Yaar - General Electric Units

UNII

BIG ROCK POINT

BROWNS FERRY 1

BROWNS FERRY 2

BROWNS FERRY 3

BRUNSWICK 1

BRUNSWICK 2

CLINTON 1

COOPER

DRESDEN 2

DRESDEN 3

DUANE ARNOLD

FERMI ?

FITZPATRICK

GRAND GULF 1

HATCH 1

HATCH 2

HOPE CREEK 1

LA SALLE 1

LA SALLE 2

LIMERICK

MILLSTONE 1
OL

DATE

AUG 62

DEC 73

AUG 74

AUG 76

NoV 76

DEC 74

APR 87

JAN 7

DEC 69

JAN 7

FEB 74

MAR 85

OC'T 7

JUL 8

$\begin{array}{lllllll}\text { AUG } 74 & 3 & 2 & 1 & 4 & 5 & 15\end{array}$

$\begin{array}{lllllll}\text { JUN } 78 & 2 & 2 & 5 & 3 & 6 & 18\end{array}$

$\begin{array}{lllllll}\text { JUL } 86 & - & \ldots & 7 & 4 & 5 & 16\end{array}$

$\begin{array}{lllllll}\text { APR } 82 & 6 & 4 & 0 & 6 & 0 & 16\end{array}$

$\begin{array}{lllllll}\text { DEC } 83 & 8 & 0 & 4 & 1 & 0 & 13\end{array}$

$\begin{array}{lllllll}\text { ОСТ } 84 & - & 2 & 1 & 2 & 0 & 5\end{array}$

$\begin{array}{lllllll}\text { ОСТ } 70 & 0 & 2 & 3 & 3 & 1 & 9\end{array}$ 
Table B. 3

BOP Trips by Year - General Electric Units (Continued)

UNIT

MONTICELLLO

NINE MILE POINT 1

NINE MILE POINT 2

OYSTER CREEK

PEACH BOTTOM ?

PEACH BOTTOM 3

PERRY 1

PILGRIM

O'JAD CITIES 1

QUAD CITIES 2

RIVER BEND 1

SHOREHAM

SUSQUEHANNA 1

SUSQUEHANNA 2

VERMONT YANKEE

WPPSS 2

MATURE PLANTS

(OL BEFORE JAN 83)

NEW PLANTS
OL

DATE

SEP 70

AUG 69

OCT 86

APR 69

AUG 73

JUL 74

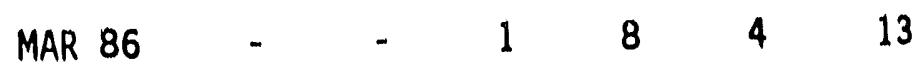

JUN $72 \quad 1 \quad 2 \quad 3 \quad-\quad \begin{array}{llll}0 & 0\end{array}$

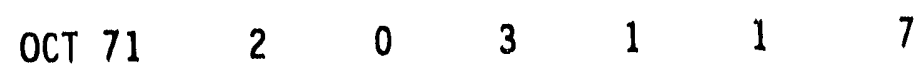

APR $72 \quad 1 \quad 2 \quad 120 \begin{array}{llll} & 4 & 4 & 11\end{array}$

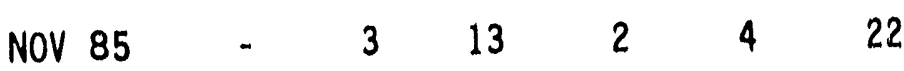

(1) 1

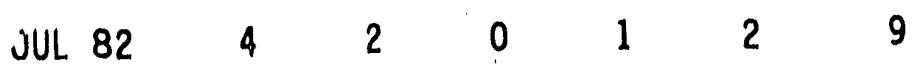

$\begin{array}{lllllll}\text { MAR } 84 & 4 & 3 & 2 & 1 & 0 & 10\end{array}$

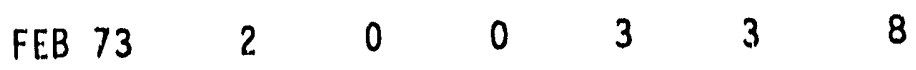

$\begin{array}{lllllll}\text { DEC } 83 & 20 & 3 & 5 & 2 & 0 & 30\end{array}$

$\begin{array}{lllllll}\text { TOTALS } & 93 & 82 & 90 & 97 & 68 & 430\end{array}$

AVG $\quad \begin{array}{llllll}2.35 & 2.54 & 2.04 & 2.26 & 1.46\end{array}$

AVG $\quad 10.67 \quad 2.83 \quad 4.63 \quad 3.80 \quad 3.00$ 
Table B.4

BOP Trips by Year - Westinghouse Untts

\begin{tabular}{|c|c|c|c|c|c|c|c|}
\hline & $0 \mathrm{~L}$ & & & $\frac{B O P}{106}$ & $\frac{\text { TRIPS }}{107}$ & & \\
\hline UNIT & DATE & 84 & $\underline{85}$ & 86 & 87 & 88 & IOTALS \\
\hline BEAVER VALLEY 1 & JAN 76 & 3 & 5 & 1 & 3 & 2 & 14 \\
\hline BEAVER VALLEY 2 & AUG 87 & - & - & - & 10 & 2 & 12 \\
\hline BRAIDWOOD 1 & MAY 87 & - & - & (1) & 6 & 2 & 9 \\
\hline BRAIDWOOD 2 & DEC 87 & - & - & - & - & 10 & 10 \\
\hline BYRON 1 & FEB 85 & - & 14 & 2 & 2 & 2 & 20 \\
\hline BYRON 2 & JAN 87 & - & - & - & 9 & 4 & 13 \\
\hline CALLAWAY 1 & JUN 84 & 10 & 12 & 4 & 1 & 6 & 33 \\
\hline CATAWBA i & JUN 85 & - & 9 & 4 & 5 & 0 & 18 \\
\hline CATAWBA 2 & MAY 86 & - & - & 8 & 7 & 6 & 21 \\
\hline CONN YANKEE & JUN 67 & 1 & 2 & 5 & 1 & 1 & 10 \\
\hline COOK 1 & ОСТ 74 & 3 & 0 & 5 & 2 & 0 & 10 \\
\hline COOK 2 & DEC 77 & 5 & 4 & 4 & 5 & 0 & 18 \\
\hline DIABLO CANYON 1 & SEP 81 & 4 & 5 & 2 & 4 & 3 & 18 \\
\hline DIABLO CANYON 2 & AUG 85 & - & 7 & 9 & 3 & 2 & 21 \\
\hline FARLEY 1 & JUN 77 & 1 & 3 & 2 & 3 & 1 & 10 \\
\hline FARLEY 2 & OCT 80 & 2 & 3 & 2 & 0 & 0 & 7 \\
\hline GINNA & SEP 59 & 1 & 5 & 3 & 0 & 2 & 11 \\
\hline INDIAN POINT 2 & SEP 73 & 5 & 8 & 6 & 0 & 4 & 23 \\
\hline INDIAN POINT 3 & DEC 75 & 5 & 6 & 6 & 5 & 4 & 26 \\
\hline KEWAUNEE & DEC 73 & 4 & 6 & 2 & 2 & 2 & 16 \\
\hline MCGUIRE 1 & JUN 81 & 1 & 4 & 3 & 1 & 2 & 11 \\
\hline MCGUIRE 2 & MAR 83 & 10 & 7 & 4 & 4 & 2 & 27 \\
\hline
\end{tabular}


Table B.4

BOP Trips by Year - Westinghouse Untts (Continued)

\begin{tabular}{|c|c|c|c|c|c|c|c|}
\hline & $\mathrm{OL}$ & & & & TRIPS & & \\
\hline UNIT & DATE & .84 & 185 & 186 & 87 & 188 & IOTALS \\
\hline MILLSTONE 3 & JAN 86 & - & - & 11 & 7 & 4 & 22 \\
\hline NORTH ANNA 1 & NOV 77 & 5 & 1 & 4 & 2 & 4 & 16 \\
\hline NORTH ANNA 2 & AUG 80 & 2 & 2 & 3 & 0 & 0 & 7 \\
\hline POINT BEACH 1 & OCT 70 & 0 & 1 & 2 & 0 & 0 & 3 \\
\hline POINT BEACH 2 & MAY 72 & 0 & 1 & 1 & 0 & 1 & 3 \\
\hline PRAIRIE ISLAND 1 & AUG 73 & 2 & 1 & 1 & 0 & 1 & 5 \\
\hline PRAIRIE ISLAND 2 & OCT 74 & 0 & 0 & 1 & 0 & 0 & 1 \\
\hline ROBINSON 2 & S.PP 70 & 0 & 7 & 3 & 2 & 3 & 15 \\
\hline SALEM 1 & AFR 77 & 7 & 1 & 7 & 1 & 3 & 19 \\
\hline SALEM 2 & $A \cup G 81$ & 7 & 7 & 9 & 3 & 5 & 31 \\
\hline SAN ONOFRE 1 & MAR 67 & 0 & 1 & 1 & 1 & 0 & 3 \\
\hline SEQUOYAH 1 & SEP 80 & 3 & 1 & - & - & 2 & 6 \\
\hline SEQUOYAH 2 & SEP 81 & 4 & 3 & - & - & 4 & 11 \\
\hline SHEARON HARRIS 1 & JAN 87 & - & - & - & 18 & 3 & 21 \\
\hline SOUTH TEXAS & MAR 88 & - & - & - & - & 3 & 3 \\
\hline SUMMER 1 & AUG 82 & 8 & 3 & 5 & 3 & 0 & 19 \\
\hline SURRY 1 & MAY 72 & 3 & 3 & 3 & 1 & 0 & 10 \\
\hline SURRY 2 & JAN 73 & 9 & 1 & 3 & 1 & 3 & 17 \\
\hline TROJAN & NOV 75 & 4 & 3 & 2 & 3 & 0 & 12 \\
\hline TURKEY POINT 3 & JUL 72 & 7 & 3 & 3 & 4 & 0 & 17 \\
\hline TURKEY POINT 4 & APR 73 & 5 & 5 & 2 & 0 & 1 & 13 \\
\hline VOGTLE 1 & JAN 87 & - & - & - & 14 & 7 & 21 \\
\hline
\end{tabular}


Table B.4

BOP Trips by Year - Westinghouse Units (Continued)

UNII

WOLF CREEK 1

YANKEE ROWE

ZION 1

ZION 2

(33) MATURE PLANTS

(OL BEFORE JAN 83)

NEW PLANTS
OL

DATE

MAR 85

JUL 60

APR $73 \quad 5$

NOV 73

TOTALS

131

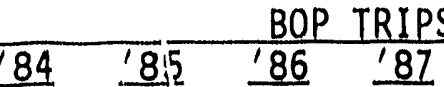

87188 TOTALS

$\begin{array}{rllll}-126 & 6\end{array}$

$\begin{array}{llllll}1 & 0 & 3 & 1 & 4 & 9\end{array}$

$\begin{array}{llllll}5 & 3 & 1 & 1 & 4 & 14\end{array}$

$\begin{array}{llllll}4 & 1 & 3 & 1 & 2 & 11\end{array}$

AVG

$\begin{array}{lllll}3.36 & 3.00 & 2.97 & 1.52 & 1.76\end{array}$

AVG

$10.00 \quad 10.20 \quad 6.00 \quad 7.08 \quad 3.53$ 
Table B.5

S.ummary Tables

Average BOP Trips per Calendar Year (1984 Through 1988)

MATURE UNITS

(OL BEFORE JAN 83)

\begin{tabular}{|c|c|c|c|c|}
\hline 184 & $\lcm{85}$ & $\underline{\prime} 86$ & $\underline{\prime} 87$ & $\underline{\prime} 88$ \\
\hline 2.43 & 4.13 & 1.86 & 1.86 & 1.62 \\
\hline 2.33 & 2.78 & 2.67 & 3.33 & 1.33 \\
\hline 2.35 & 2.54 & 2.04 & 2.26 & 1.46 \\
\hline 36 & 3.00 & 2.97 & 1.52 & 1.76 \\
\hline
\end{tabular}

W (33 UNITS)

B\&W (8 UNITS)

CE ( 9 UNITS)

GE (26 UNITS)

3.36

3.00

2.97

(OL $\frac{\text { NEW UNITS }}{\text { BEFORE JAN }}$

83)

$\lcm{84}$

$\underline{85}$

$\lcm{186}$

$\lcm{87} \quad \underline{88}$

B\&W (NONE)

CE (2 TO 6 UNITS)

5.00

7.75

4.00

3.20

1.00

GE (3 TO 11 UNITS)

10.67

2.83

4.63

3.80

3.00

$W$ (2 TO 15 UNITS)

$10.00 \quad 10.20$

6.00

7.08

3.53 
APPENDIX C

BOP Trips per Critical Year by Plant

(Nurmalized Data, 1984-1988) 


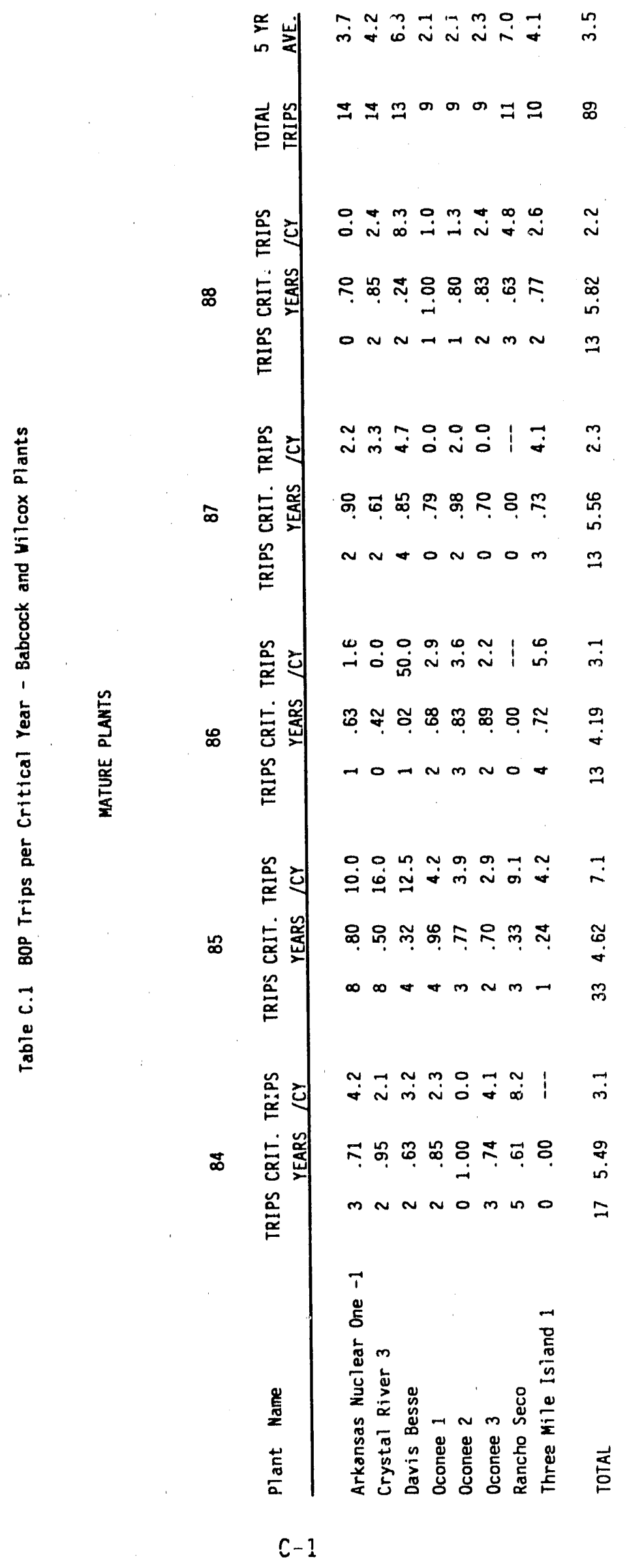




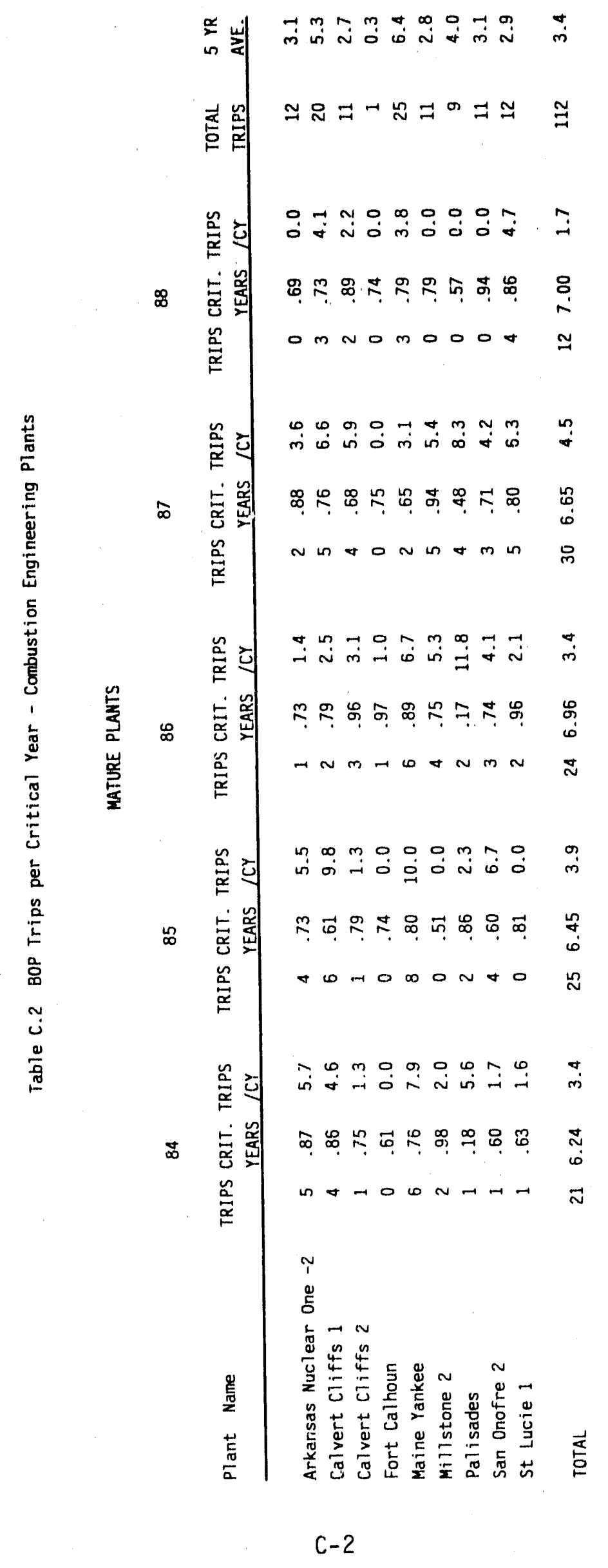




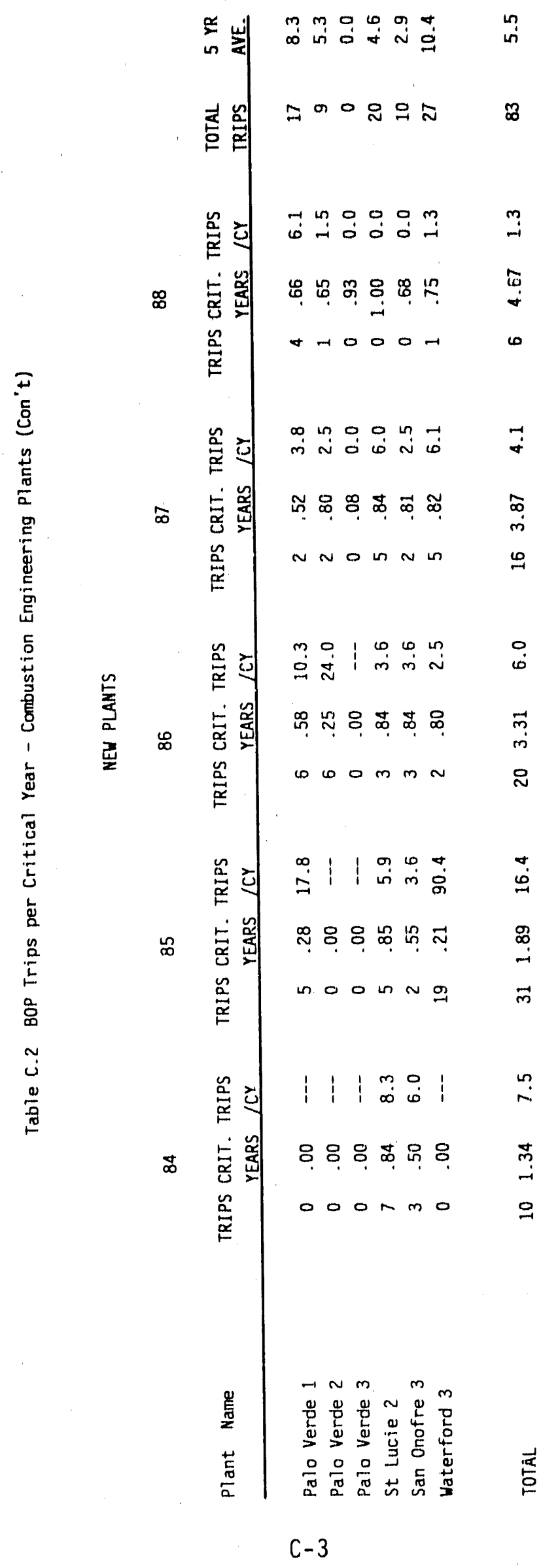


幽

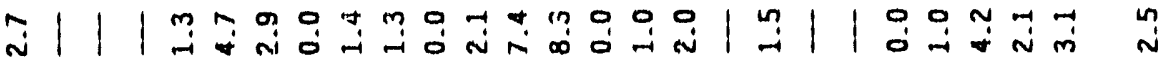

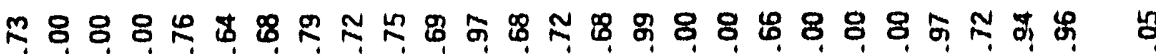
黛

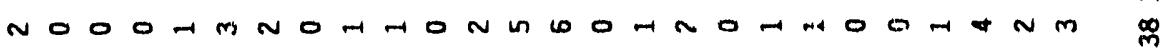

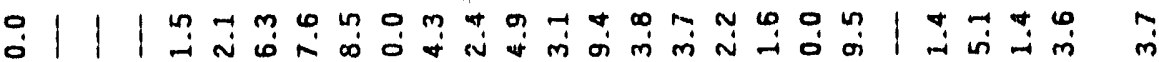

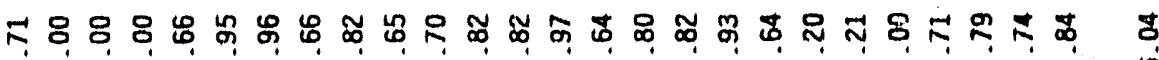
怘

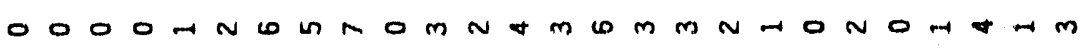

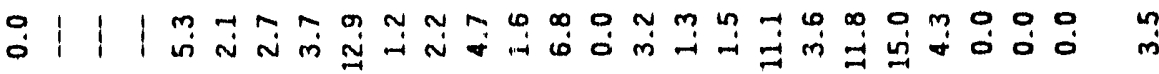

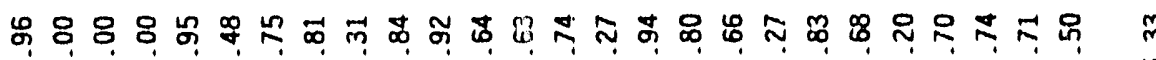
oto 0 M $-N m$ N

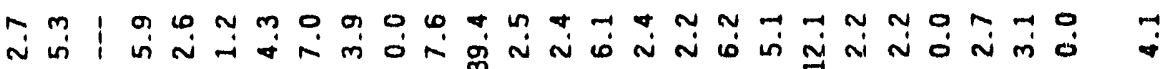
年星

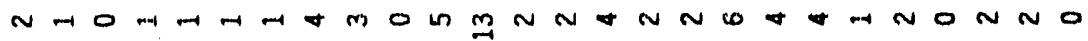

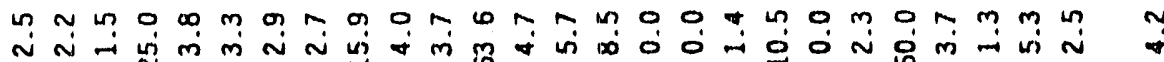

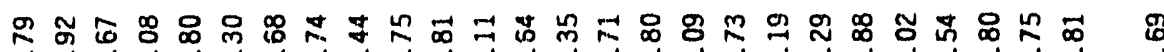

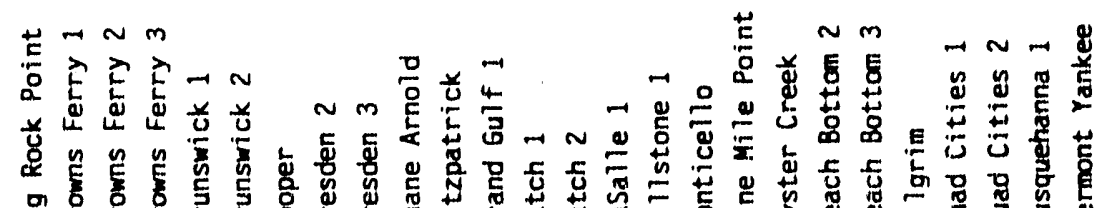

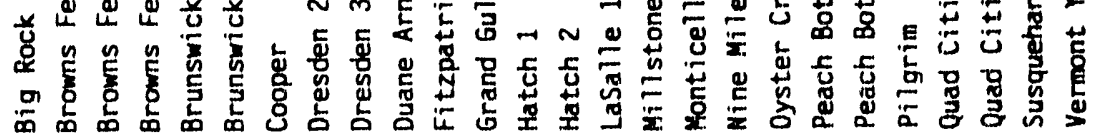




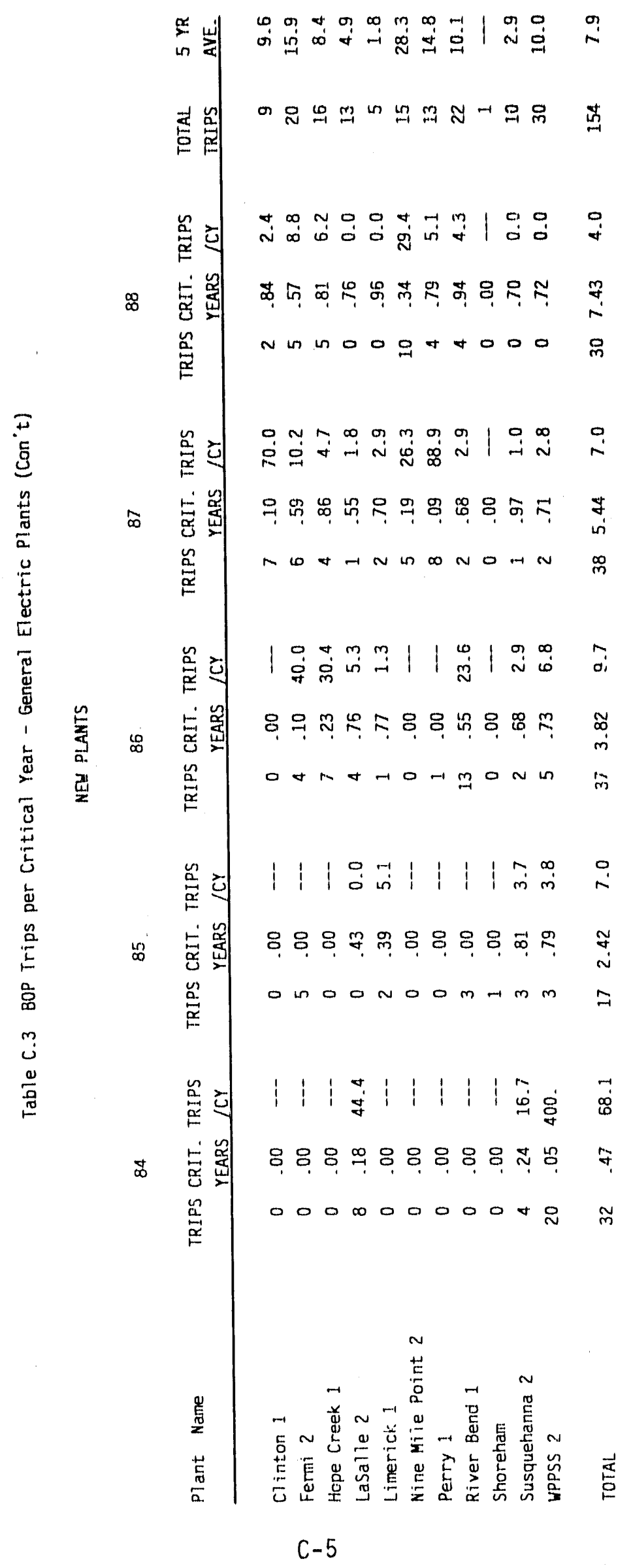




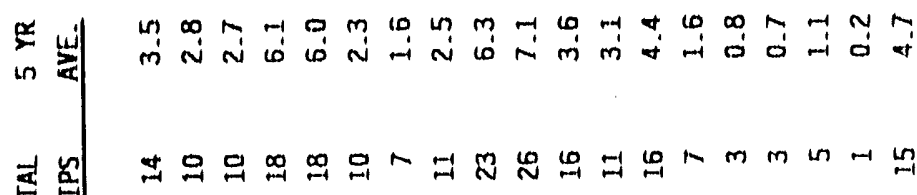

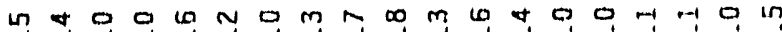

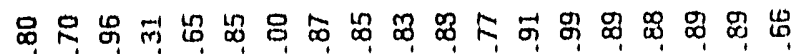
正

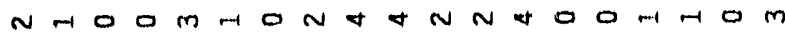

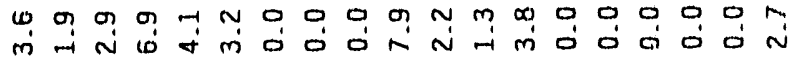

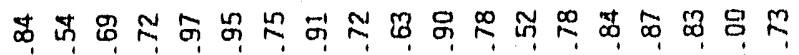
高

অ.

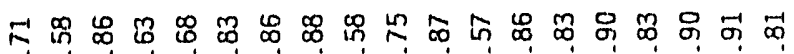

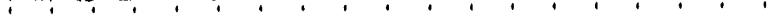

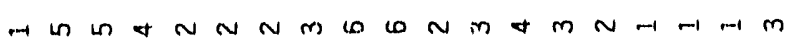

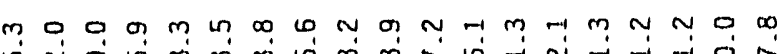
ฟก

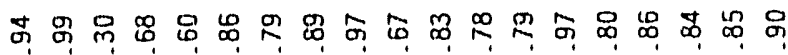
总

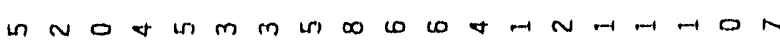

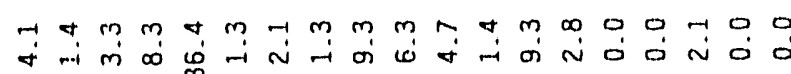
营

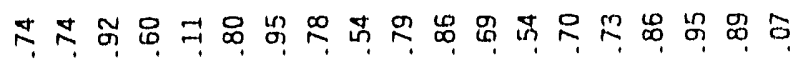

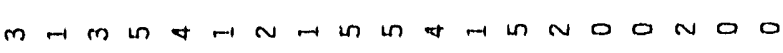




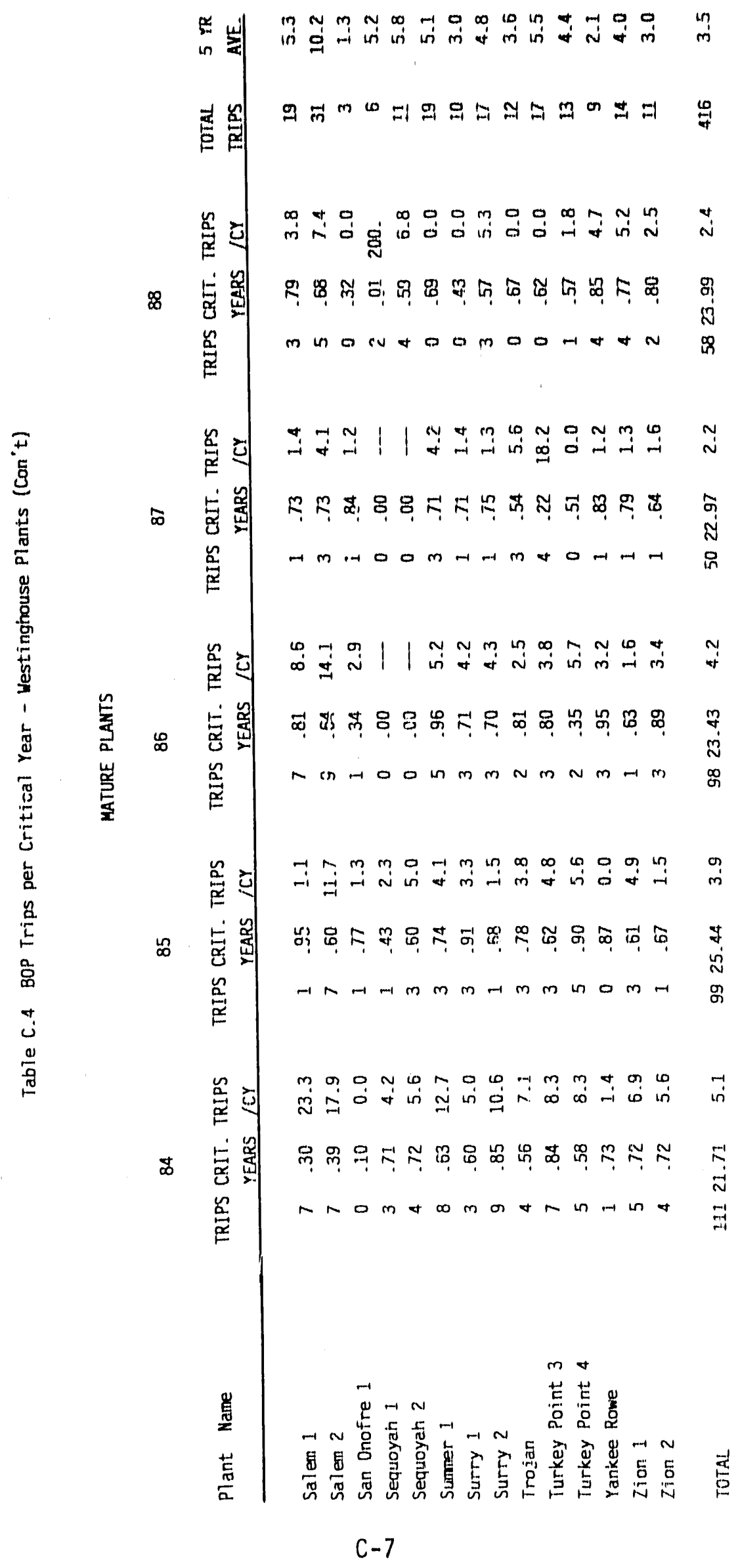




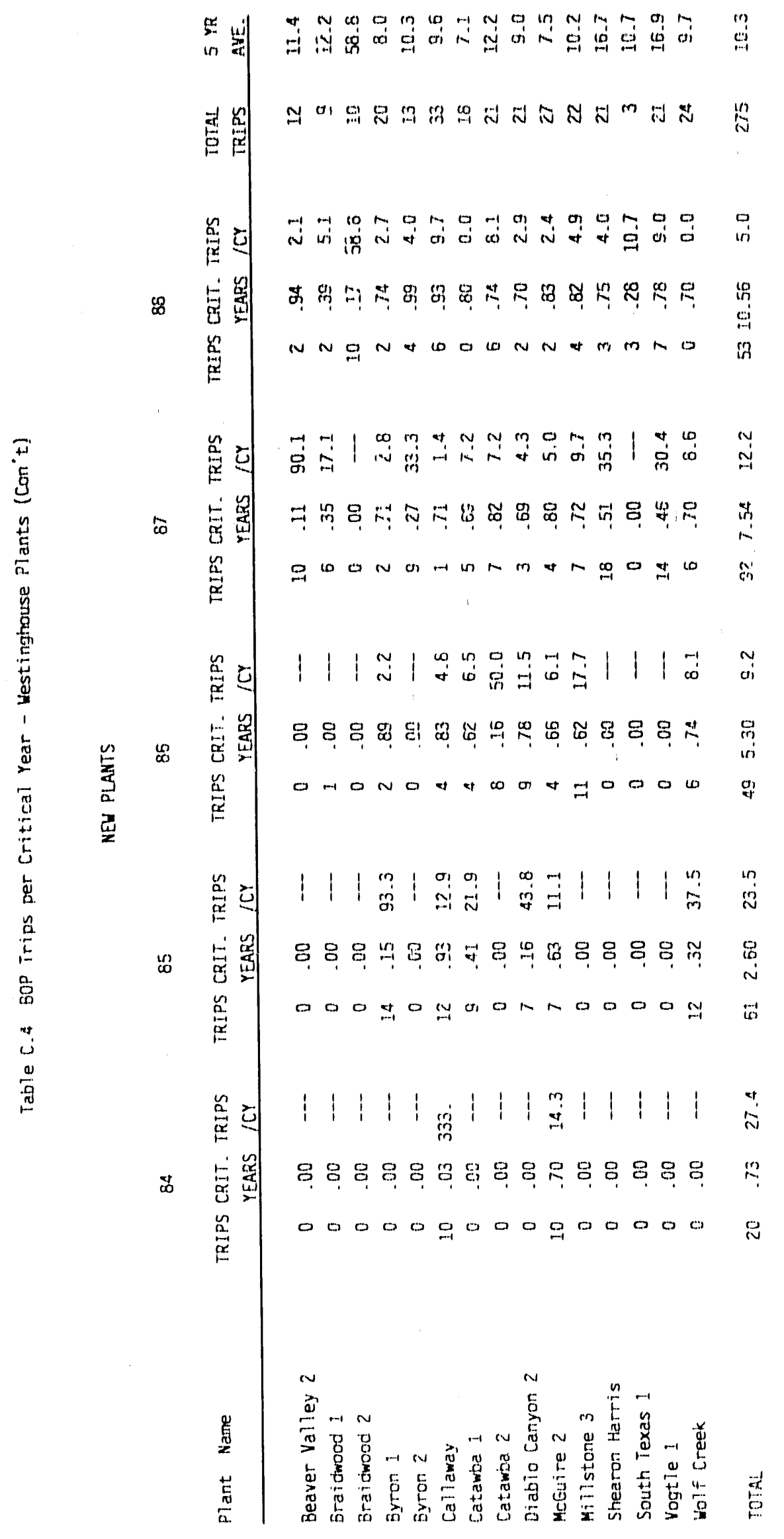




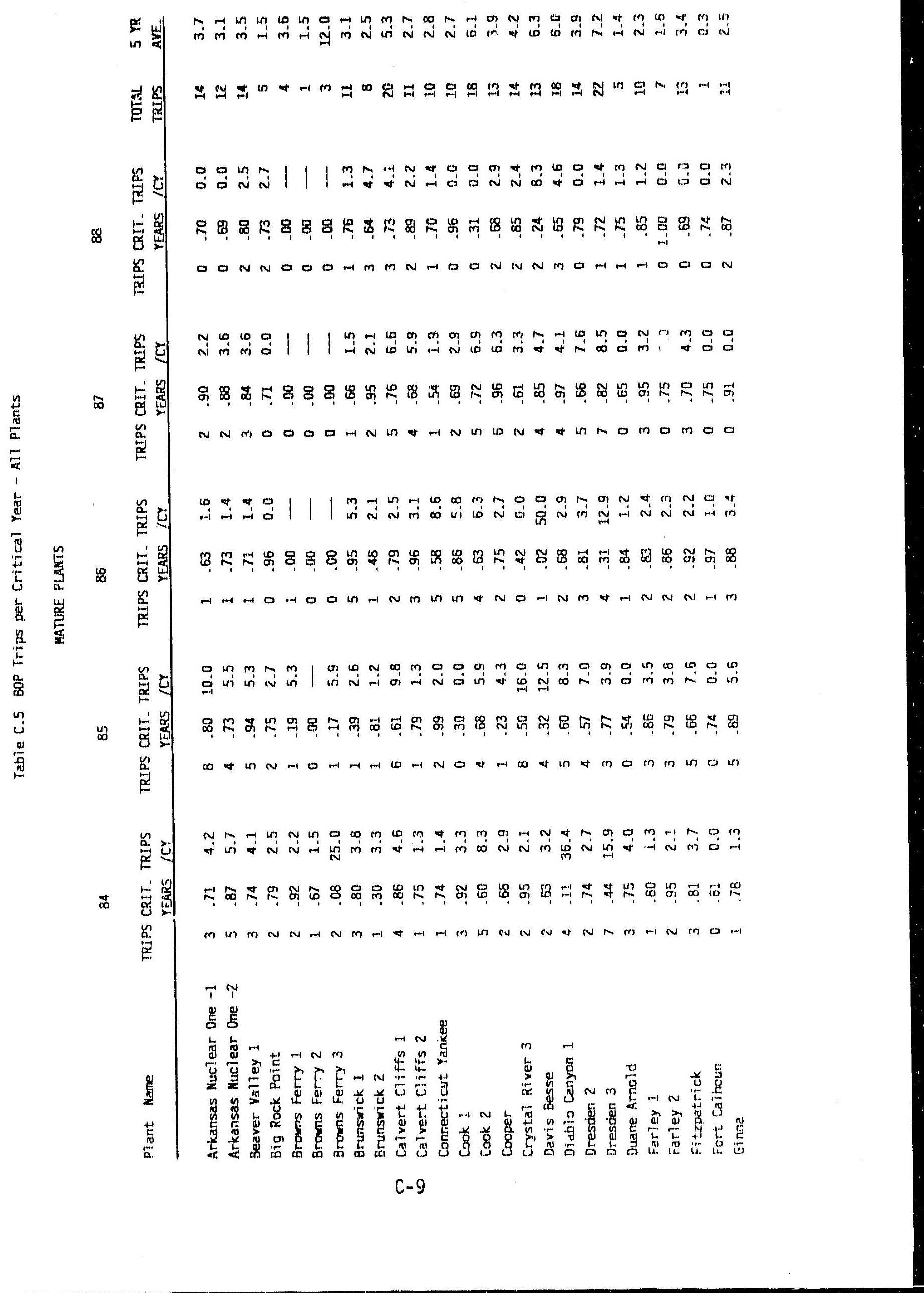




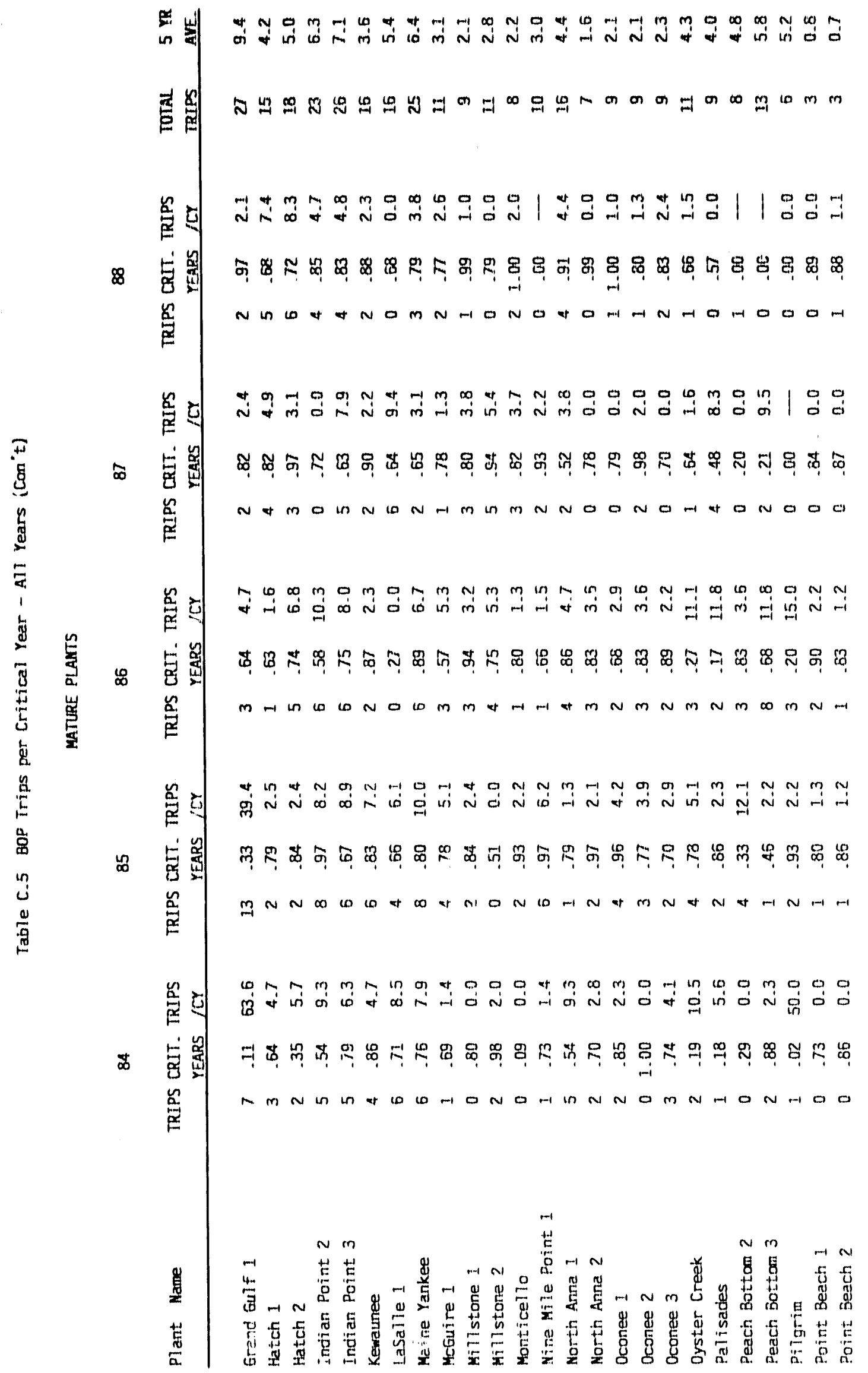




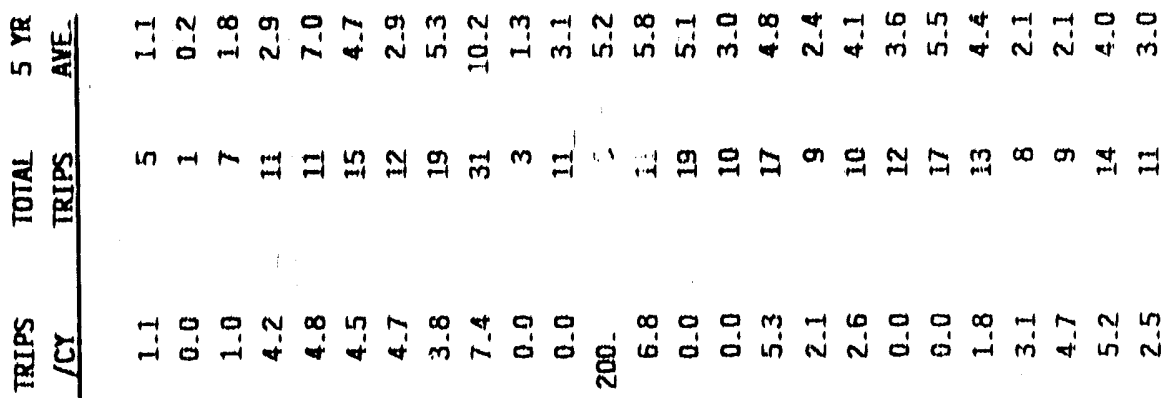

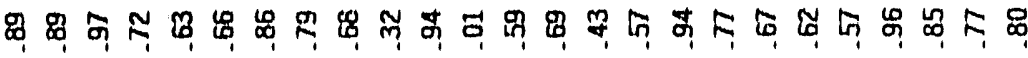
है

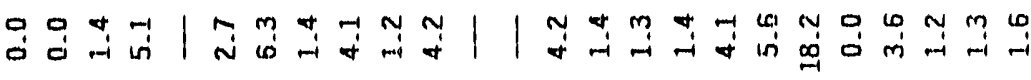

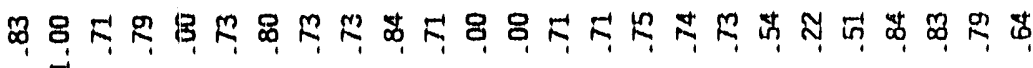
参

ت્木

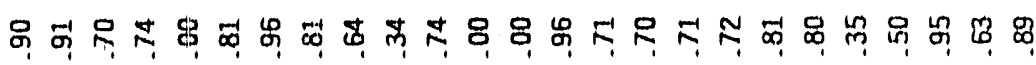

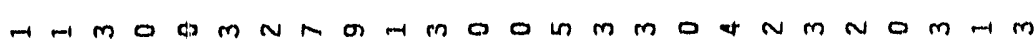

No에

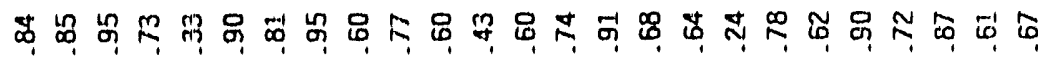

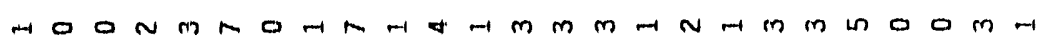

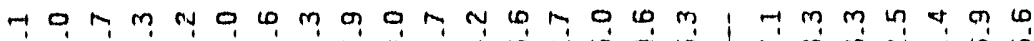

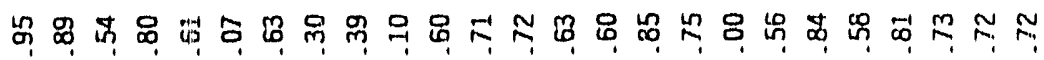
NON-W W W

号苞 


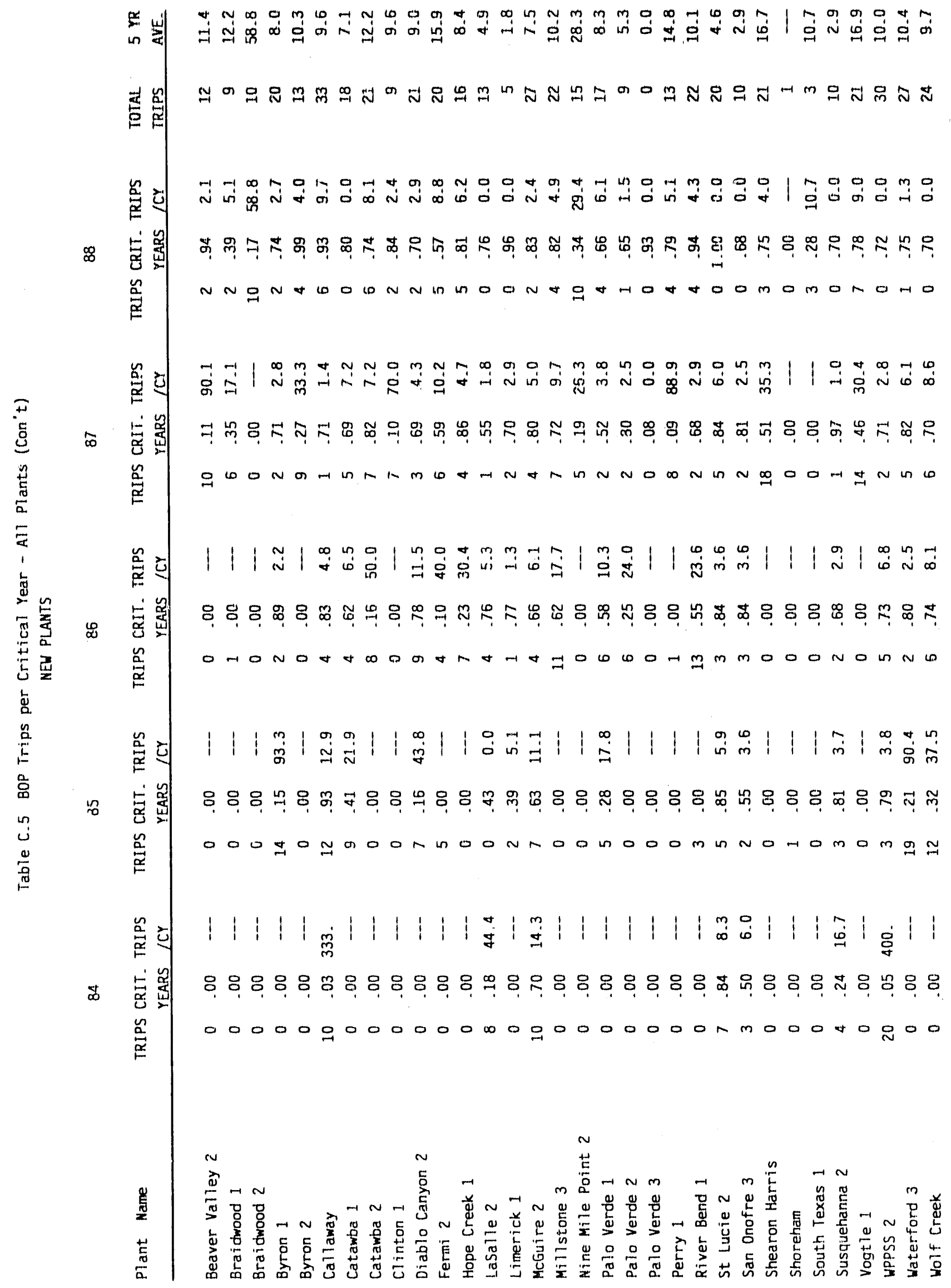


APPENDIX D

BOP Trips per Critical Year by Plant (Cumulative Average, 1984-1988) 
Table 0.1

List of BOP Trips by Plant per Critical Year: Cumulative Average for B\&W Units

Plant Name

Arkansas Nuclear One - 1

Crystal River 3

Davis Besse

Oconee 1

Oconee 2

Oconee 3

Rancho Seco

Three Mile Island 1

*** Subtotal $\star \star \star$

All plants*: Average=
OL Date

$12 / 09 / 74$

$12 / 03 / 76$

$04 / 22 / 77$

$02 / 06 / 73$

$10 / 06 / 73$

$07 / 19 / 74$

$08 / 16 / 74$

$04 / 19 / 74$

8 Units

$\begin{array}{cc}\text { Critical } & \text { BOP Trips } \\ \text { Years } & 1 / 84 \\ & 12 / 88 \\ \end{array}$

3.70

3.33

2.06

4.28

4.38

3.86

1.57

2.46

2.46

8. Units

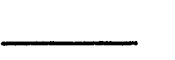

14

14

13

9

9

9

11

10

5-Yr Average BOP Trips per Critical Year

Critical Year

3.78

4.20

6.31

2.10

2.05

2.33

7.01

4.07

89

31.86

* All B\&W plants are in the "Mature" category, OL before 1/1/83 
Table D.2

List of BOP Trips by Plant per Critical Year: Cumulative Average for CE Units

Plant Name

Arkansas Nuclear One - 2

Calvert Cliffs 1

Calvert Cliffs 2

Fort Calhoun 1

Maine Yankee

Millstone 2

Pal isades

Palo Verde 1

Palo Verde 2

San Onofre 2

San Onofre 3

st. Lucie 1

st. Lucie 2

Waterford 3

*** Subtotal ***

All Plants: Average $=$

Mature Plants*: Average=

New Plants ${ }^{\star \star}$ : Average $=$

* 9 plants with ol before $1 / 183$

* 5 plants with OL after $1 / 1 / 83$
OL Date

$07 / 18 / 78$

$07 / 31 / 74$

$08 / 13 / 76$

$05 / 24 / 73$

$06 / 01 / 73$

$08 / 01 / 75$

$10 / 01 / 72$

$12 / 31 / 84$

$12 / 09 / 85$

$09 / 07 / 82$

$09 / 16 / 83$

$03 / 01 / 76$

$04 / 06 / 83$

$12 / 18 / 84$

14 Units

$\begin{array}{cc}\text { Critical } & \text { BOP Trips } \\ \text { Years } & 1 / 84- \\ & 12 / 88\end{array}$

3.89

3.74

4.08

3.82

3.90

3.97

2.25

2.04

1.71

3.59

3.38

4.06

4.37

2.59

\begin{abstract}
4.44
\end{abstract}
sigma $=$

195

5-Yr Average

Bop Trips per

Critical Year

3.08

5.35

2.70

0.26

6.41

2.77

4.00

8.33

5.26

3.06

2.96

2.96

4.58

10.42

62.15

3.40 sigma $=\quad 1.64$

6.31 sigma=

2.69 
Table 0.3

BOP Trips by Plant per Critical Year: Cumulative Average for GE Units

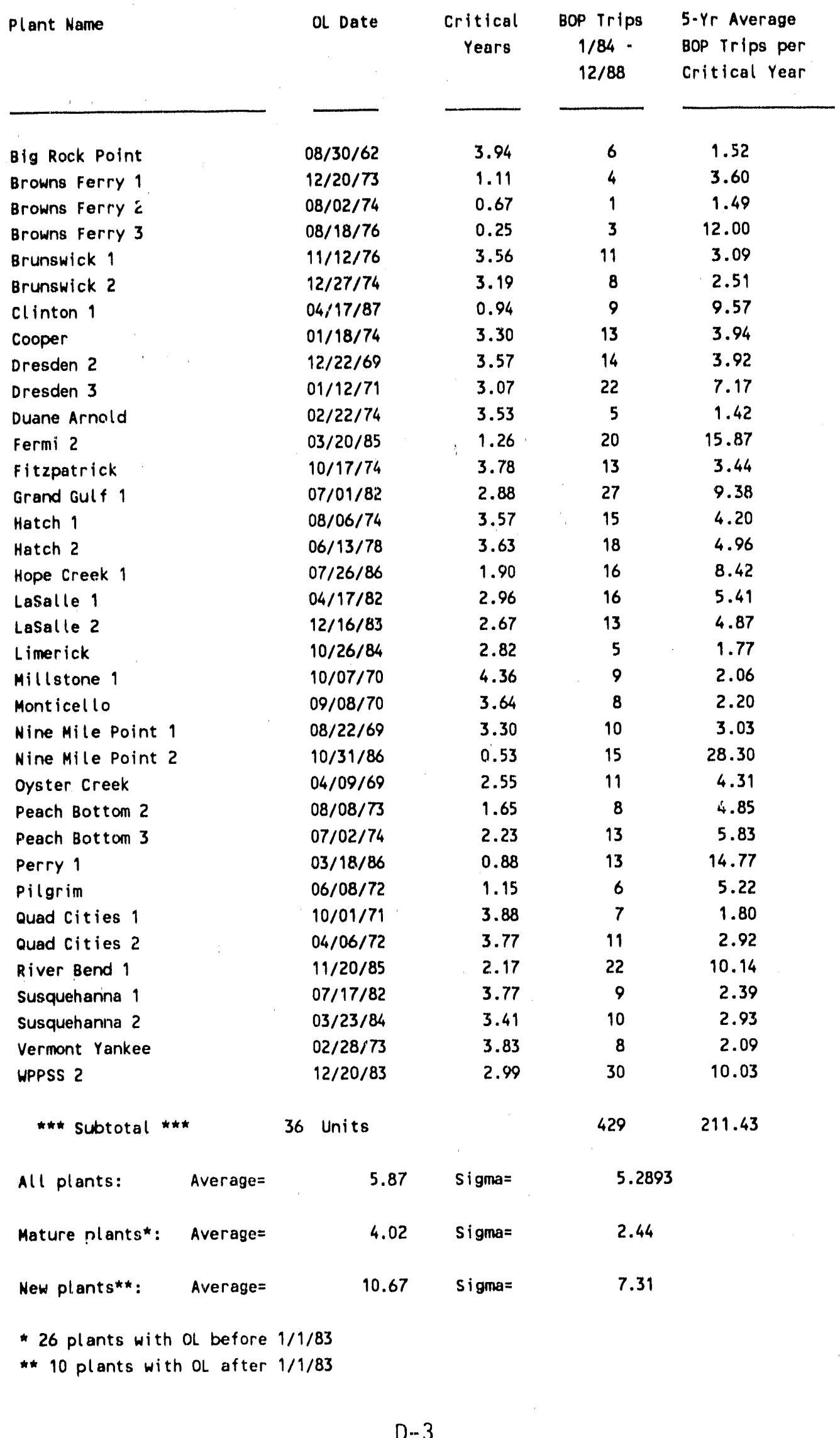


Table 0.4

BOP Trips by Plant per Critical Year: Cumulative Average for Westinghouse Units

Plant Name

Beaver Valley 1

Beaver Valley 2

Braidwood 1

Braidwood 2

Byron 1

Byron 2

Callaway 1

Catawba 1

Catawba 2

Connecticut Yankee

Cook 1

Cook 2

Diablo Canyon 1

Diablo Canyon 2

Farley 1

Farley 2

Ginna

Indian Point 2

Indian Point 3

Kewaunee

McGuire 1

McGuire 2

Millstone 3

North Anna 1

North Anna 2

Point Beach 1

Point Beach 2

Prairie island 1

Prairie Island 2

Robinson 2

Salem 1

Salen 2

San Onofre 1

Sequoyah 1

Sequoyah 2

Shearon Harris 1

South Texas 1

summer 1

surry 1

Surry 2

Trojan

Turkey Point 3

Turkey Point 4

Vogtle 1
OL Date

$08 / 01 / 37$

$05 / 21,187$

$12 / 18 / 87$

$02 / 14 / 85$

$01 / 30 / 87$

$06 / 11 / 84$

$06 / 01 / 85$

$05 / 01 / 86$

$06 / 30 / 67$

$10 / 25 / 74$

$12 / 23 / 77$

$09 / 22 / 81$

$08 / 26 / 85$

$06 / 25 / 77$

$10 / 23 / 80$

$09 / 19 / 69$

$0: 128 / 73$

$12 / 12 / 75$

$12 / 21 / 73$

$06 / 29 / 81$

$03 / 01 / 83$

$01 / 31 / 86$

$11 / 26 / 77$

$08 / 21 / 80$

$10 / 05 / 70$

$05 / 25 / 72$

$08 / 09 / 73$

$10 / 29 / 74$

$09 / 23 / 70$

$04 / 06 / 77$

$08 / 18 / 81$

$03 / 27 / 67$

$09 / 17 / 80$

$09 / 15 / 81$

$01 / 12 / 87$

$03 / 22 / 88$

$08 / 06 / 82$

05/25/72

$01 / 29 / 73$

$11 / 21 / 75$

$07 / 19 / 72$

$04 / 10 / 73$

$01 / 16 / 87$

$\begin{array}{cc}\text { Critical } & \text { BOP Trips } \\ \text { Years } & 1 / 84 \\ & 12 / 88\end{array}$

1.05

0.75

0.17

2.49

1.25

3.44

2.53

1.72

3.55

3.72

2.94

3.01

2.33

4.28

4.35

4.34

3.67

3.68

4.34

3.60

3.62

2.16

3.63

4.28

4.17

4.30

4.41

4.54

3.16

3.59

3.04

2.49

1.18

1.92

1.26

0.28

3.73

3.35

3.55

3.36

3.09

2.92

1.24
5. Yr Average

80P Trips per

critical Year

3.47

11.43

12.00

58.82

8.03

10.40

9.59

7.11

12.21

2.82

2.69

6.12

5.98

9.01

2.34

1.61

2.53

6.27

7.07

3.69

3.06

7.46

10.19

4.41

1.64

0.72

0.70

1.13

0.22

4.75

5.29

10.20

1.20

5.08

5.73

16.67

10.71

5.09

2.99

4.79

3.57

5.50

4.45

16.94 
Table 0.4

Bop Trips by Plant per Crittcal Year: Curmulative Average for Westinghouse Units (Cont inued)

Plant Name

Wolf Creek 1

Yankee-Rowe

2 ion 1

zion 2

*** Subtotal $\star \star \star *$
OL Date

$07 / 09 / 60$

$04 / 06 / 73$

$11 / 14 / 73$

48 Units

$\begin{array}{cc}\text { Critical } & \text { Bop Trips } \\ \text { Years } & 1 / 84 \\ & 12 / 88\end{array}$

2.46

4.23

3.50

3.71

6.97

3.76

Sigma=

14.02

sigma=

8.5381

2.12

12.29
5-Yr Average

BOp Trips per

Critical Year

9.76

2.13

4.00

2.96

691

334.52

All plants: Average=

Average=

sigma

* 33 plants with ol before 1/1/83

** 15 plants with ol after $1 / 1 / 83$ 
APPENDIX E

BOP Trips by Systems and Subsystems 
Reactor Trips Counted by Bop systems and subsystems

Bop system

AC Power

AC Power

AC Power

AC Power

AC Power

AC Power

subtotal:

AC Power, Feedwater

Subtotal:

Air

Alr

Air

Subtotal:

Air, Feedwater

Subtotal:

Auxiliary Feedwater

Auxillary Feedwater

Subtotal:

Circulating Water

Circulating Water

circulating Water

Subtotal:

Communications

Subtotal:

Component Cooling Water

Subtotal:
BOp susbsyatem

High Voltage

High Voltage offsite

Low Vol tage

Medium Vol tage

Vital AC (120V)

No. of Trips

4

77

3

6

31

47

168

Low Voltage

1

1

Compressor

Prefilter system

42

1

44

1

1

2

AFW Initiation and Control

2

4

24

Lube 011

Lube ofl cooling Water

2

E-1 
Reactor Tripe counted by sop syotems and subaystem.

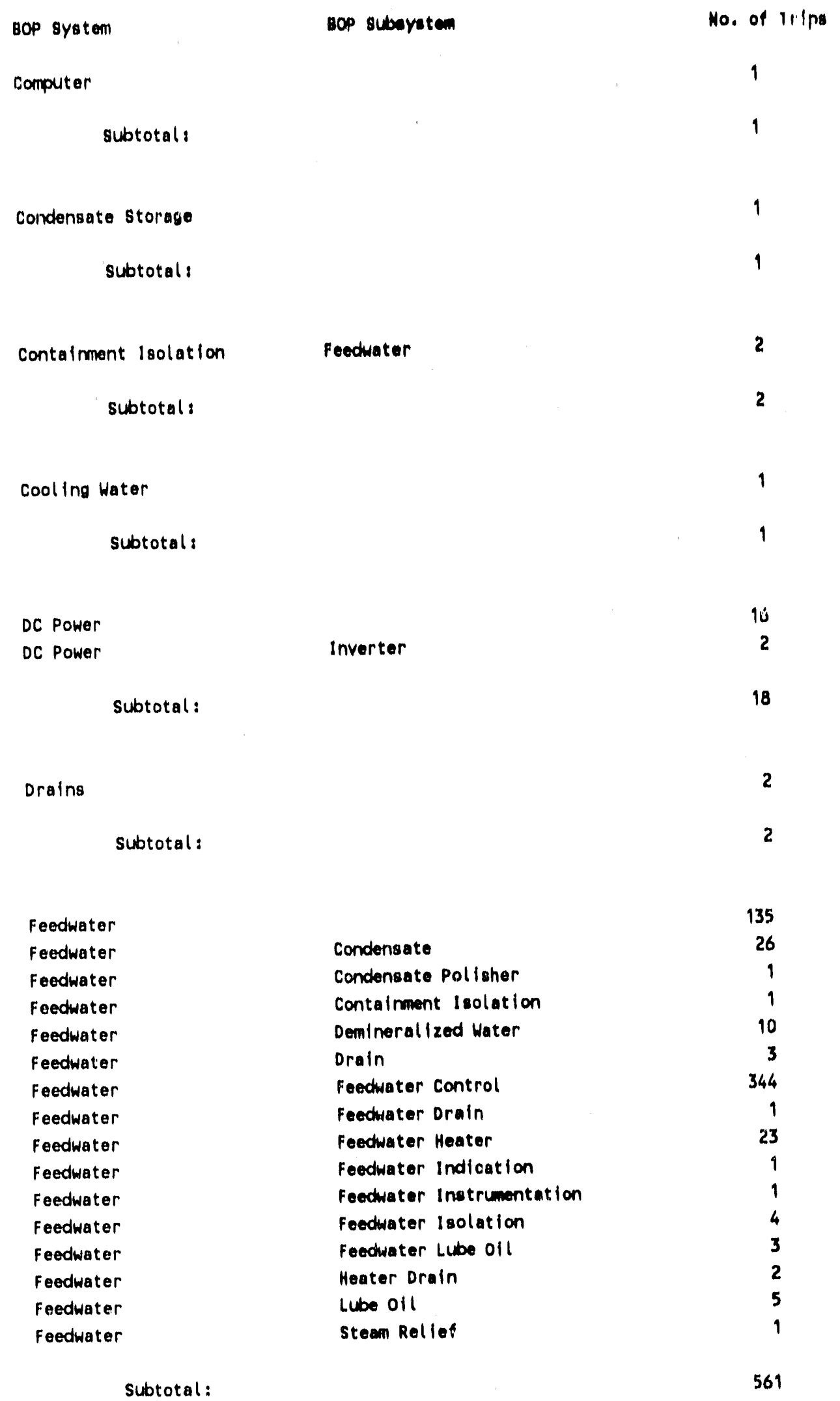


Reactor Trlpa Counted by BOP syatems and subsyatems

Bop syatem

Foedwater, Main stoam

subtotal:

Feodwater, steam Generator

subtotaly

Pire Protection

subtotals

HVAC

HVAC

HVAC

HVAC (BuIlding)

subtotal:

HVAC Turbine bufleing

subtotal:

Instrumentation and control Instrumentation and control instiumeritation and control Instrumentation and Control Instrumentation and control instrumentat ion and control Instrumentation and control instrumentation and control instrumentation and control

Subtotal: subtotal:
BOp subsystem

Peeciwater control

No. of Trips

1

1

Foedwater Control

1

1

4

4

3

Battery Room Coolling

Cabinet cooling

1

1

5

2

2

1

1

Control Room Instrimentation

Feodwater Control

Nuclear instrumentation

Power Range linstrumentution

RCP Trip circult

Radiation

safeguarda Logic

steam Generator Control

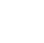

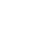

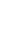

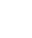

4

4

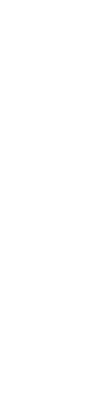

1




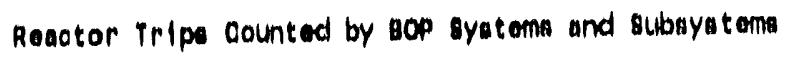

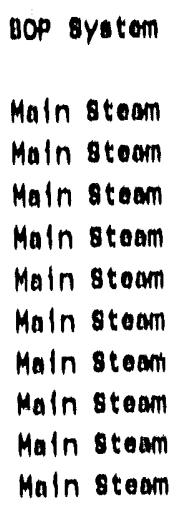

subtotal:

Primary system Drain

subtotals

RWCU Dralna

subtotal: 
Roaotor Trlpe Counted by sop syatorns and subsystems

Bop syutem

Hoastor Coolant Pur I 18C

subtotals

Ronctor Coolant Pump oil

subtotals

Solamlo Trlp

subtotals

Sorvioo Water

Subtotal

Steam denorator

stoam Qoneratol

stean Denerator

Steam Generator

steam Qonerator

stoam Donerator

subtotal:

Turbine Generator

rurbine Generator

Turbine aenerator

Turbine denerator

Turbine cenerator

Turbine Oenerator

Turbine conerator

Turbine Generator

Turbine Generator

Turbine denerator

rurbine Generator

Turbine Generator

Turbine denerator

Turbine Qenerator

Turbine Generator

Turbine denerator

Turbine Generntor

Turbine Cenerator

Turbine Generator oop subsyatem

No, of Trips

Instrumantation

sa Blowdown Drain

sa Low Level Trip

Steam Generator Amnonia supply

steam denerator Control

Condenser

Cooling Wator

Drain

Excltar

Qurnerator

Qenerator Cooling Water

Generator Hydrogen Control

Qenerutor Hydrogon Sonl oll

Qenerator stator Cooling

Libe oll

Pressure Regulator

steam Jot Alr Ejoctor

steam Rellef

stoam sealing

T/a Instrumentation \& Control

Thruet Bearing Wear Dotoctor

Turbine

Turbino aypass
1

1

1

1

2

87

列

7

33

1

9

2

1

2

1

8

3

1

1

1

250

1

3

2 
Roactor Tripa Countion by bop syatema and subsystems

Bop syatem

Turbine aenerator Turbine cenerator Turbine denerator Turbine Generator Turblne denerator rurbine Qenerator

oubtotal.

Turbine aenerator, Feodwater $9 / 0$ Instrumentation \& Control

subtotals

Unlinown

BOp subiays tom

Turbine control oll

rurbine coollng Water rurbine Drain Turbine lube 011 Turbine Lube oll Cooler rurbine steem sealling

Ya Inatrumentation a control$$
\text { subtotals }
$$

subtotal:
Ho. of Tripo

1

2

1

3

1

3

419

1

1

1

1

1405

$E-6$ 
APPENDIX $\mathrm{F}$

BOP Trips by Systems and Components 
Reactor, Trips Counted by BOP Components and systems

BOP Syetem

AC Power

AC Power

AC Power

AC Power

AC Power

AC Power

AC Power

AC Power

AC Power

AC Power

AC Power

AC Power

AC Power

AC Power

AC Power

AC Power

AC Power

AC Power

AC Power

AC Power

AC Power

AC Power

AC Power

AC Power

AC Power

ic Power

AC Power

AC Power

AC Power

AC Power

AC Power

AC Power

AC Power

AC Power

AC Power

Subtotal:

AC Power, Feedwater

Subtotal:

Air

Air

Air

Air

Air
Bop Component

No. of Trips

$345 \mathrm{KV}$ test block stud

Auxiliary transformer

Bus

Bus duet

Cable

Capacitor

circuit breaker

circuit card

Computer

Conduit

Connection

Connector

control circuit

Fuse

Human

Human (other unit)

Input filter

Insulation

Inverter

Inverter, Fuse

Lightning arrester

Main transformer

Multiplexer

Oscillator

Oscillator, Voltage controller

Rectifier, Fuse

Relay

Switch

Switchgear cabinet

Test switch

Transformer

Transmission line

Unknown

Hire

Air control valve, Air line

Air dryer

Air line

Air line moisture trap

Compressor
1

1

5

4

2

10

1

5

50

6

1

1

1

7

1

1

1

23

2

8

3

2

14

1

2 
Reactor Trips Counted by BOP Component and Systems

BOP System

Air
Air
Air
Air
Air
Air
Air
Air
Air
Air

Air, Feedwater

Subtotal:

Auxiliary feedwater

Auxiliary Feedwater

Auxiliary Feedwater

Subtotal:

Circulating Water

Circulating Water

circulating Water

circulating Water

Circulating Water

Circulating Water

Circulating water

Circulating Water

Circulating Water

Circulating Water

Circulating Water

Circulat ing Water

Circulating Water

Circulating Water

Subtotal:

Communications

Subtotal:
BOP Component

No. of Trips

Compressor, Pressure switch

Fastener, Pressure transmitter

Human

Insulation

Pipe

Relay

Solenoid valve

Unknown

Unknown (Contaminant)

Valve

1

1

11

1

3

1

1

2

2

1

44

Air line, Feedback arm

1

Human

Pipe

Transmitter/Receiver

1

1

4

Circuit card

Human

Isolation valve

Jet pump

Motor operated valve

Multiplexer

Pump

Relay

screen

Strainers

Transmitter

Traveling screen

Unknown

Valve

1

5

1

1

1

1

3

1

1

1

1

5

1

4

27

Hand held radios

1

1 
Reactor Trips Counted by BOP Component and Systems

BOP Systam

Component Cocling Hater

Subtotal:

Computer

Subtotal:

Condensate Storage

Subtotal:

Contaimment I solation

Containment Isolation

Subtotal.

Cooling Water

Subtotal:

DC Power

DC Power

DC Power

DC Power

DC Power

DC Power

DC Power

DC Power

Subtotal:

Drains

Drains

Subtotal:

Feedwater

Feedwater

Feedwater

Feedwater

Feedwater
BOP Component

Human

No. of Trips

1

Inverter

1

1

1

1

Fuse

Solenoid valve

1

Human

1

1

Bus

Circuit card

Control circuit

DC power scurce

Humar.

Inter lock

Unknown

Hire

Pipe

Weld

Air operated valve

Air regulator

Bistable

Bypass valve

Capacitor
1

2

1

10

1

1

1

2

1 
Reactor Trips Counted by BOP Component and Systems

BOP System

Feedwater

feedwater

Feedwater

Feedwater

Feedwater

Feedwater

Feedwater

Feedwater

Feedwater

Feedwater

Feedwater

Feedwater

Feedwater

Feedwater

Feedwater

Feedwater

feedwater

Feedwater

Feedwater

feedwater

Feedwater

Feedwater

Feedwater

Feedwater

Feedwater

Feedwater

Feedwater

Feedwater

Feedwater

Feedwater

feedwater

Feedwater

Feedwater

Feedwater

Feedwater

Feedwater

feedwater

Feedwater

Feedwater

Feedwater

Feedwater

Feedwater

Feedwater

Feedwater

Feedwater

Feedwater

Feedwater

Feedwater

Feedwater
BOP Component

No. of Trips

Check valve

check valve, circuit breaker

check valve, Pump

circuit breaker

circuit card 29

circuit card, Valve

Computer

Condensate demineral izer

Condensate polisher programer

Connection

Control circuit

Control oil

Control valve

Current-pressure converter

DC power source

DC power source, FW ht lev cntrl switch

Deaerator tank

Delta P controller

Diaphram

Drain tank

FWP delta $P$ controller meter

Feed regulator valve, bypass

Feedwater control valve

Feedwater heater

Feedwater regulator valve

Feedwater regulator valve, Block valve

Feedwater square root extractor

flow controller

flow recorder

Flow transmitter

Flyball governor

Fuse

Heat exchanger

Heater Drain Tank

High signal selector

Human

Indicator

Level controller

Level recorder

Level sensor

Level switch

Level transmitter

Limit switch

Lube oil seperator

Manual isol valve, air operated valve

Manual valve

Motor operated valve

Nozzle

oil filter

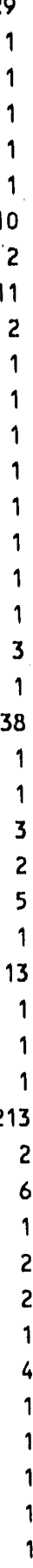


Reactor Trips Counted by BOP Component and Systems

BOp System

Feedwater

Feedwater

Feedwater

Feedwater

Feedwater

Feedwater

Feedwater

Feedwater

Feedwater

Feedwater

Feedwater

Feedwater

Feedwater

Feedwater

Feedwater

Feedwater

Feedwater

Feedwater

Feedwater

Feedwater

Feedwater

Feedwater

Feedwater

Feedwater

Feedwater

Feedwater

Feedwater

Feedwater

Feedwater

Feedwater

Feedwater

Feedwater

Feedwater

Feedwater

Feedwater

Feedwater

Feedwater

Feedwater

Feedwater

Feedwater

Feedwater

Subtotal:

Feedwater, Main Steam

Human

Pipe

Pump

Relay

Seal

switch

Tube

valve

Wire
Bop Component

oil line

oil line, Wire

oil seal

oil/water separator

Pneumatic valve

Potentiometer

Power supply

Pressure Control

Pressure switch

Pressure transmitter

Recirculation valve

Regulator valve

Relay contacts

Relief valve

Rupture disk

Servo control motor

solenoid valve

Solenoid valve, isolation valve

speed controller

speed indication

steam/Feed mismatch summator

strainers

Tachometer

Thrust bearing wear detector

Transmitter

Trip circuit

Trip switcli

Turbine governor

Turbine pump

Unknown

Valve operators, Relays, Solenoid valve

vent line

Vibration detector

Subtotal:
561

No. of Trips

3

1

1

1

1

3

5

31

1

2

10

1

2

1

2

1

12

1

5

$$
1
$$

1

2

5

1

1

1

1

1

3

2

2

21

23

1

1

1

6

1 
Feedwater, steam Generator

Subtotal:

Fire Protection

Fire Protection

Fire Protection

Subtotal:

HVAC
HVAC
HVAC

HVAC

Subtotal:

HVAC (Building)

Subtotal:

HVAC Turbine building

Subtotal:

Instrumentation and Control Instrumentation and Control Instrumentation and Control Instrumentation and control Instrumentation and control Instrumentation and Control Instrumentation and control Instrumentation and control Instrumentation and control Instrumentation and control Instrumentation and Control Instrumentation and Control Instrumentation and control instrumentation and control

Subtotal:
Human 2

Pressure regulator, Sensing header pipe Unknown

Fan

Human

Unknown

4

1

2

2
5

2

Human 1

1

Amplifier

Capacitor

Circuit card

Connection

Human

Instrumentation

Inverter

Level transmitter pressurizing valve

Power supply

Radiation monitor

Relay

Static inverter, Switches

Transformer 1

Unknown 1

Air operated check, valve

3

Bypass valve 
Reactor Trips Courited by BOP Component and Systems

BOP system

Main Steam

Main Steam

Main Steam

Main steam

Main steam

Main steam

Main Steam

Main steam

Main Steam

Main Steam

Main Steam

Main Steam

Main Steam

Main steam

Main Steam

Main steam

Main steam

Main Steam

Main Steam

Main Steam

Main Steam

Main Stean

Main stean

Main Steam

Main Steam

Main Steam

Main Steam

Main Steam

Main Steam
BOP Component

No. of Trips
Check valve

circuit card

Control circuit

Drain tank

Drain valve

Gasket

Human

Human, Unknowis

Insulation

Level controller

Level switch

Limit switch

Main Steam Isolation Valves

Pipe

Pneumatic valve

Pressure control valve

Pressure switch

Pressure transducer

Pressure transmitter

Pump

Relay

Rellef valve

Solenoid valve

Trip circuitry

Trip switch

Trip valve

Unknown

valve

Vent line
1

3

3

1

1

3

33

1

1

2

2

1

2

2

1

1

2

1

3

1

2

3

3

1

1

1

3

6

1

90

Subtotal:

Non-condensible Gases Extract. Human

Subtotal:

Non-nuclear Instrumentation Non-nuclear Instrumentation Non-nuclear Instrumentation Flow switch Non-nuclear Instrumentation Fuse holders Human Non-nuclear Instrumentation valve 
Bop system

Panels/Cabinets

Subtotal:

Power Conversion

Subtotal:

Primary system Drain

subtotal:

RUCU Drains

Subtotal:

Reactor Coolant Pump 18C

Subtotal:

Reactor Coolant Pump oil

Subtotal:

Seismic Trip

Subtotal:

Service Water

Subtotal:

Stean Generator

Stean Generator

Steam Generator

steam Generator

Steam Generator

stean Generator

Subtotal:
BOp Component

Human

No. of Trips

1

1

Pipe

1

1

Valve

1

Pipe

1

Relay

1

1

Level switch

1

1

Coil, relay

Human

Bypass valve

1

Control circuit

flow transmitter

Humen

Relief valve

Valve

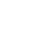

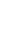

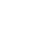


Turbine Generator Turbine Generator Turbine Generator Turbine cenerator Turbine Generator Turbine Generacor Turbine Generator Turbine Generator Turbine Generator Turbine Generator Turbine cenerator Turbine Generator Turbine Generator Turbine Generator Turbine denerator rurbine Generator Turbine Generator Turbine aenerator Turbine Generator Turbine denerator Turbine cenerator Turbine Generator Turbine Generator Turbine Generator Turbine Generator Turbine Generator Turbine Generator Turbine Generator Turbine Generator rurbine Gererator rurbine Generator Turbine cenerator Turbine Generator Turbine Generator Turbine Generator Turbine Generator Turbine Generator Turbine Generator Turbine Generator Turbine Generator rurbine Generator Turbine Generator Turbine Generator Turbine Generator Turbine Generator Turbine Generator Turbine Generator Turbine Generator Turbine Generator

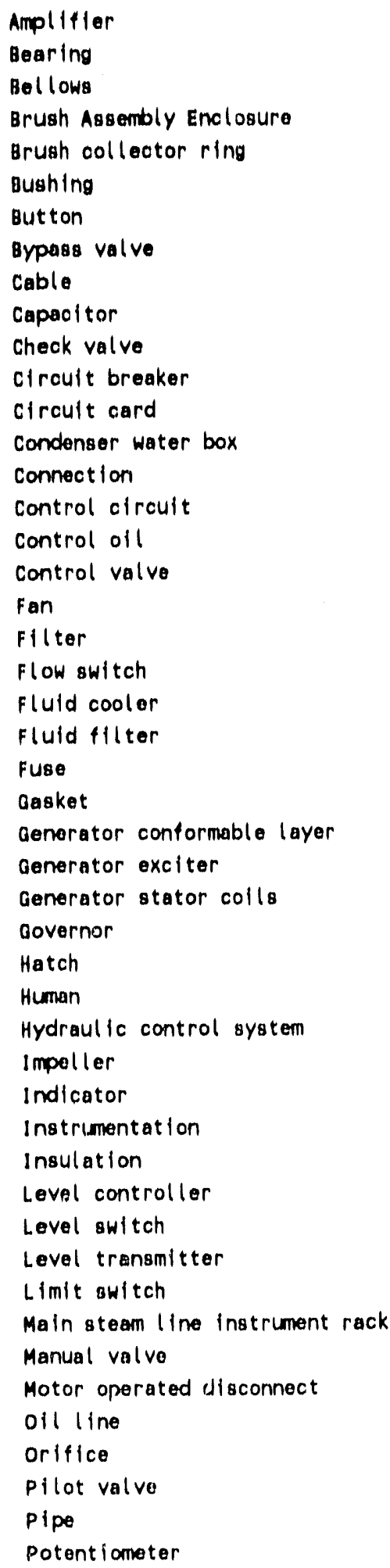


Turbine denerator Turbina Cenerator Turblne generator Turblno Qenerator Turbine Generator Turbine denerator Turbine denerator rurbine oenerator Turbine denerator rurbina neneratar Turbine cenerator Turbine Generator Turbine oenerator rurbine Generator Turbine Generator Turblne Denerator Turbine Generator Turbine Generator Turbine oenerator rurbine aenerator rurbine denerator Turbine Generator Turbine denerator rurbine cenerator Turbine conerator Turbine Generator Turblne aenerator Turbine Generator Turbine Generator Turblne Generator rurbine Generator rurbine Qenerator Turbine aenerator Turbine Generator Turbine Generatar Turbine Generator Turbine Generator Turbine Generator Turbine Qenerator Turbine Generator Turbine Generator Turbine Generator Turbine aenerator Turbine cenerator Turbine Generator Turbine cenerator Turbine Generator Turbine Generator Turbine Generator

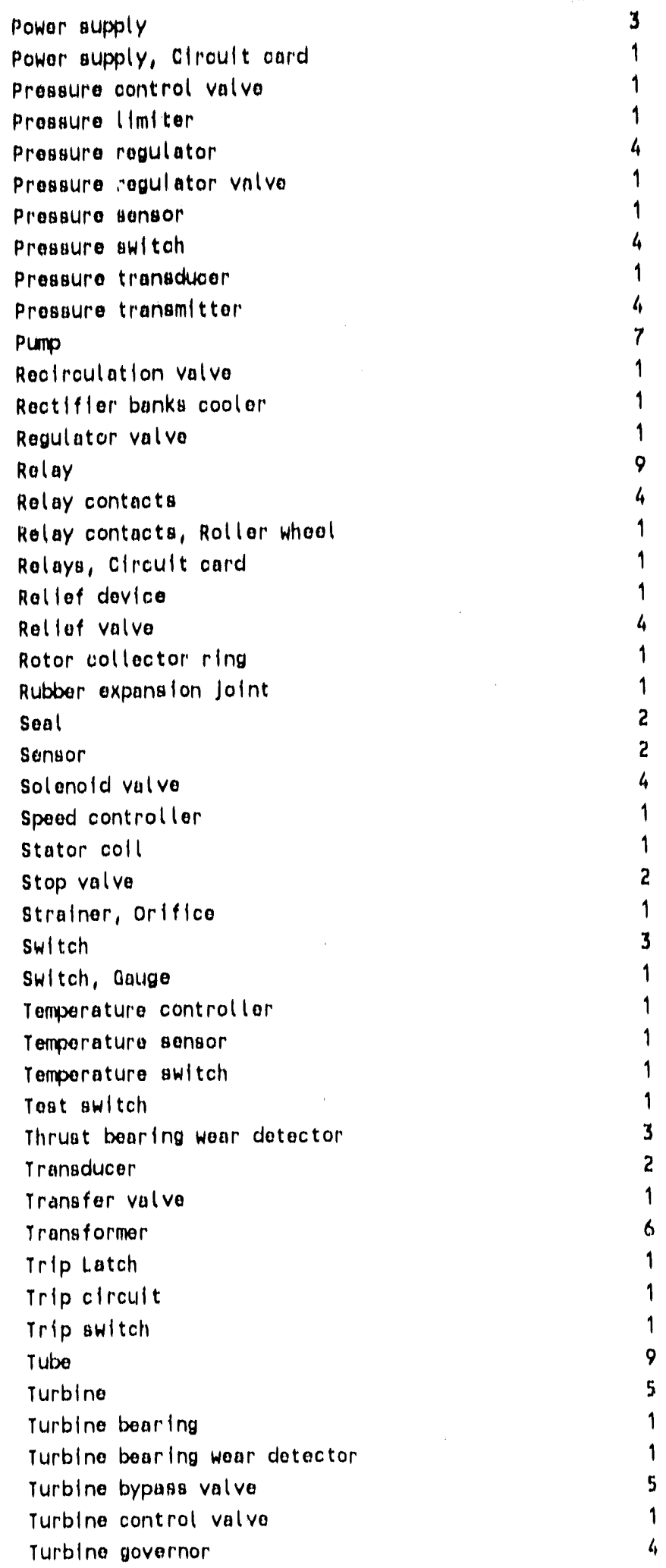


Reactor Trlpu Counted by bop Componant and systoms

Hop oystem

Turblne Denerator

Turb/no annerator

rurblne denerator

Turblne oenerator

Turbine denerator

Turblne denerator

Turblne denerator

Turbine Denerator

Turbine aenerator

Turblne oenerator

Turbline Oenerator

subtotals

Turbine cenerator, feedwater

subtotals

Unknown

subtotal:

Unknown

Bop Componerit

Turblin govornor valvo

rurbine governor valve, bypase valvo

Turbine hoader press. hand/auto atation

Turbine atop valve

Unknown

Valve

Vibration detector

Vibration Indloator

voltase reoulatior

Hold

WIro

No, of Trips

9

1

1

3

25

7

1

1

2

1

4

419

Reluy, Turbine foedpump coupl Ing

1

1

1

1

Total No. of Trips: 
APPENDIX G

Mature Plants' Feodwater Pumping Capacity 
MATURE PLANTS' FEEDWATER PUMPING CAPACITY

\begin{tabular}{|c|c|c|c|c|c|}
\hline Plant & $(\%)$ & (Mmmotori $T=t u r b t n e)$ & BOP & 非 & Ew Control \\
\hline 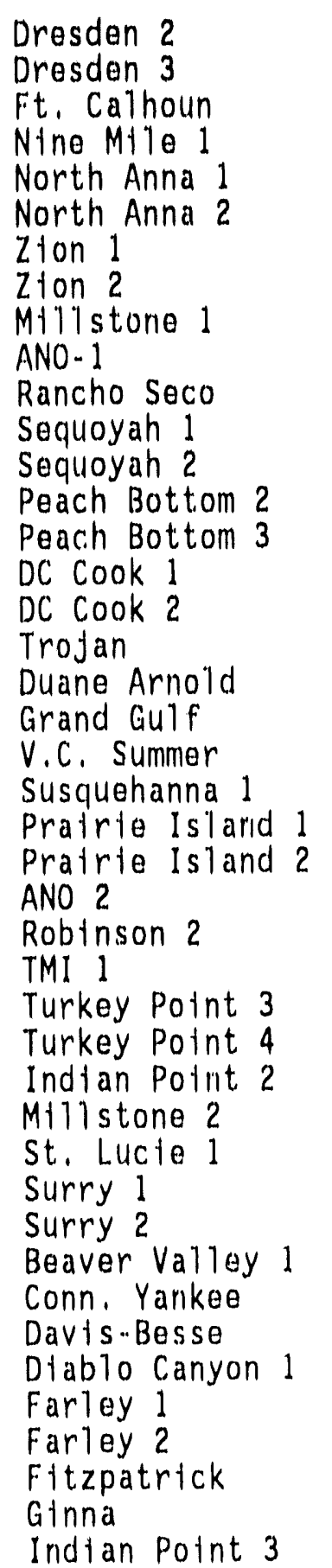 & $\begin{array}{l}100 \\
100 \\
100 \\
100 \\
100 \\
100 \\
100 \\
100 \\
87 \\
80 \\
80 \\
78 \\
78 \\
72 \\
72 \\
70 \\
70 \\
70 \\
68 \\
67 \\
67 \\
67 \\
65 \\
65 \\
60 \\
60 \\
60 \\
60 \\
60 \\
55 \\
55 \\
55 \\
55 \\
55 \\
50 \\
50 \\
50 \\
50 \\
50 \\
50 \\
50 \\
50 \\
50\end{array}$ & $\begin{array}{c}3 M \\
3 M \\
3 M \\
3(M / T) \\
3 M \\
3 M \\
3(M / T) \\
3(M / T) \\
3 M \\
2 T \\
2 T \\
2 T \\
2 T \\
3 T \\
3 T \\
2 T \\
2 T \\
2 T \\
2 M \\
3 T \\
3 T \\
3 T \\
2 M \\
2 M \\
2 T \\
2 M \\
2 T \\
2 M \\
2 M \\
2 T \\
2 T \\
2 M \\
2 M \\
2 M \\
2 M \\
2 M \\
2 T \\
2 T \\
2 T \\
2 T \\
2 T \\
2 M \\
2 T\end{array}$ & $\begin{array}{l}5.0 \\
8.9 \\
0.3 \\
3.0 \\
4.4 \\
1.8 \\
3.6 \\
3.1 \\
2.4 \\
4.6 \\
8.5 \\
3.5 \\
5.3 \\
4.2 \\
5.8 \\
3.6 \\
6.8 \\
3.6 \\
1.4 \\
12.6 \\
6.3 \\
2.5 \\
1.1 \\
0.3 \\
4.6 \\
4.8 \\
4.7 \\
6.9 \\
5.1 \\
6.8 \\
3.5 \\
2.5 \\
3.4 \\
5.2 \\
3.7 \\
3.2 \\
4.9 \\
6.4 \\
2.6 \\
2.1 \\
4.2 \\
2.6 \\
7.7\end{array}$ & $\begin{array}{r}2.1 \\
3.4 \\
0 \\
0.9 \\
2.2 \\
0 \\
1.1 \\
1.4 \\
0.6 \\
3.0 \\
4.3 \\
0.9 \\
3.8 \\
1.8 \\
2.7 \\
2.2 \\
2.3 \\
1.5 \\
0.4 \\
5.2 \\
2.7 \\
0.4 \\
0.8 \\
0 \\
1.2 \\
2.0 \\
1.2 \\
0.8 \\
0.8 \\
3.9 \\
1.9 \\
1.9 \\
1.4 \\
2.6 \\
0.6 \\
1.8 \\
3.8 \\
2.1 \\
1.4 \\
1.5 \\
1.6 \\
0.3 \\
4.9\end{array}$ & $\begin{array}{r}2.1 \\
3.0 \\
0 \\
0.9 \\
1.5 \\
0 \\
0.7 \\
1.0 \\
0.3 \\
3.0 \\
3.2 \\
0.9 \\
1.5 \\
1.2 \\
1.3 \\
1.8 \\
1.9 \\
0.9 \\
0 \\
1.0 \\
0.7 \\
0.4 \\
0.6 \\
0 \\
1.2 \\
2.0 \\
1.2 \\
0.7 \\
0.4 \\
3.6 \\
1.3 \\
1.6 \\
0 \\
1.5 \\
0.6 \\
0.7 \\
2.7 \\
1.3 \\
1.2 \\
0.9 \\
0.3 \\
0.3 \\
3.5\end{array}$ \\
\hline & & $G=1$ & & & \\
\hline
\end{tabular}


MATURE PLANTS FEEDWATER PUMPING CAPACITY (Cont inued)

Trips per Crittcal Year

"N-1"

Jan. 1, 1984 - early 1988

Plant

Capactty

Number of FW Pumps

(\%) (MmotoriT-turbtne) BOP EW EW Control

Kewaunee

Paltsades

Point Beach 1

Point Beach 2

Salem 1

Salem 2

San Onofre 1

San Onofre 2

50

50

50

50

50

50

50

50
$2 M$
$2 T$
$2 M$
$2 M$
$2 T$
$2 T$
$2 M$
$2 M$
$4.1 \quad 1.8$

$5.4 \quad 0.6$

$0.7 \quad 0.0$

$0.7 \quad 0.0$

$5.8 \quad 3.6$

$12.3 \quad 5.5$

1.5

3.8

2.

2.3

1.8

0

0.0

0.0

2.2

4.7

0

0.4 


\section{APPENDIX H}

BOP Trips by Plant with NSSS Vendor and $A / E$ 
Reactor Trips Counted by Plant

(with Associated NSSS Vendors

and by $A / E$ Firms

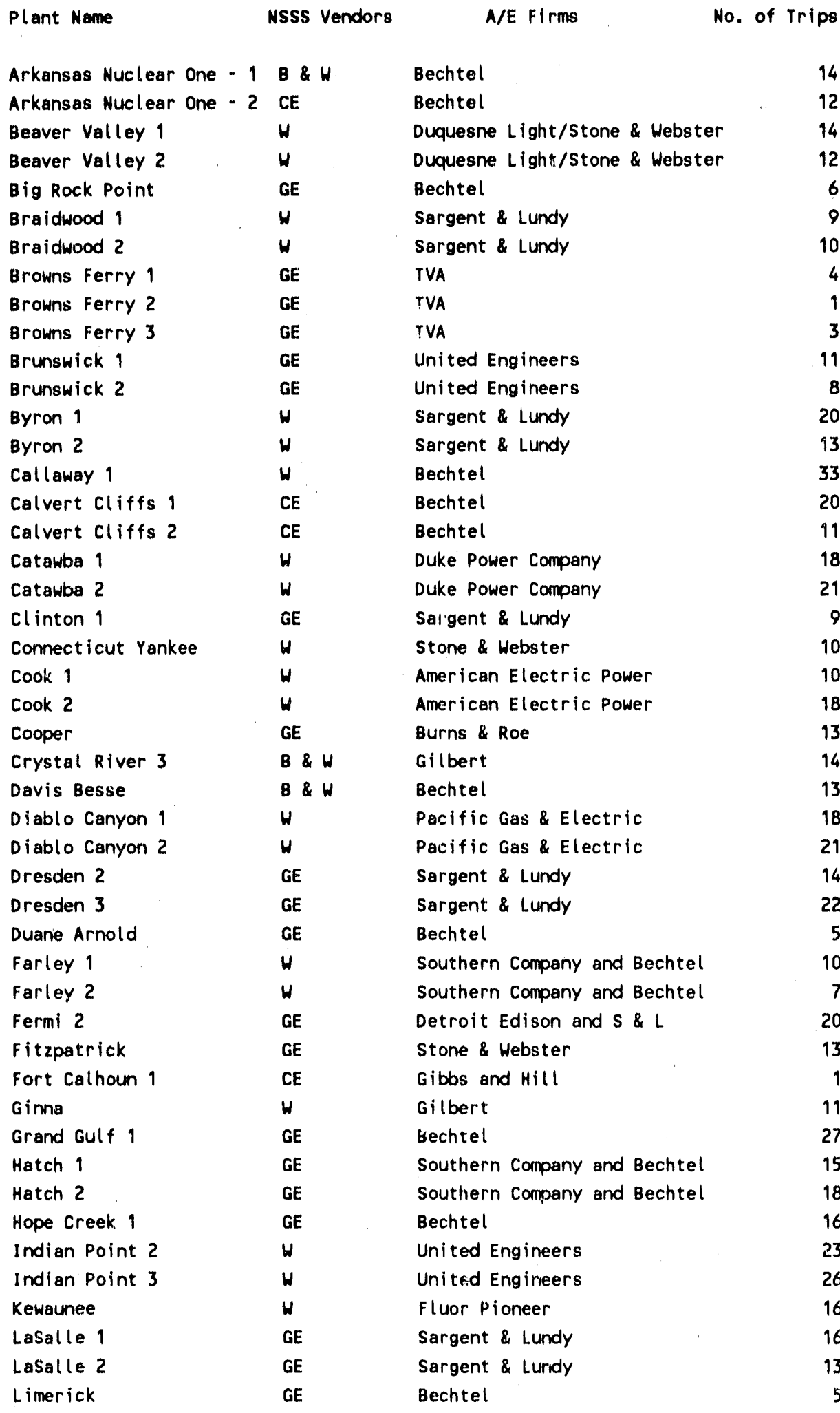


Reactor Trips Counted by Plant

(with Assoclated NSSS Vendors

and by $A / E$ firms

Plant Name

Maine Yankee

McGuire 1

McGuire 2

Millstone 1

Millstone 2

Millstone 3

Mont icel lo

Nine Mile Point 1

Nine Mile Point 2

North Anna 1

Nortín Anna 2

Oconee 1

Oconee 2

Oconee 3

Oyster Creek

Pal isades

Palo Verde 1

Palo Verde 2

Peach Bottan 2

Peach Botton 3

Perry 1

Pilgrim

Point Beach 1

Point Beach 2

Prairie Island 1

Prairie Island 2

Quad Cities 1

Quad cities 2

Rancho Seco

River Bend 1

Robinson 2

Salem 1

Salem 2

San Onofre 1

San Onofre 2

San Onofre 3

Sequoyah 1

Sequoyah 2

Shearon Harris 1

\section{shoreham}

South Texas 1

St. Lucie 1

St. Lucie 2

summer 1

Surry 1

Surry 2

Susquehanna 1
NSSS Vendors

A/E Firms

No. of Trips

CE

$$
\text { H }
$$$$
\text { W }
$$

GE

CE

H

GE

GE

CE

$W$

$W$

B \& $W$

B \& $\mathrm{H}$

B \& $H$

GE

CE

CE

CE

GE

GE

GE

GE

$W$

$W$

W

$W$

GE

GE

B \& $H$

GE

H

$W$

$H$

W

CE

CE

W

W

W

GE

$H$

CE

CE

H

$W$

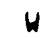

GE

Stone \& Webster 25

Duke Power Company 11

Duke Power Compariy 27

Ebasco 9

Bechtel 11

Stone \& Webster 22

Bechtel 8

Niagara Mohank Power Corp. $\quad 10$

Stone \& Hebster 15

Stone \& Hebster 16

Stone \& Wabster $\quad 7$

Duke and Bechtel 9

Duke and Bechtel 9

Duke and Bechtel 9

Burns \& Roe and GE (Turnkeyl) 11

Bechtel 9

Bechtel : 17

Bechtel 9

Bechtel 8

Bechtel 13

Gilbert 13

Bechtel 6

Bechtel 3

Bechtel 3

Fluor Pioneer 5

Fluor Pioneer 1

Sargent \& Lundy 7

Sargent \& Lundy 11

Bechtel 11

Stone \& Webster 22

Ebasco 15

Public Service Electric \& Gas 19

Public Service Electric \& Gas 31

Bechtel 3

Bechtel 11

Bechtel 10

TVA 6

TVA 11

Ebasco 21

Stone \& Webster 1

Bechtel 3

Ebasco 12

Ebasco 20

Gilbert 19

Stone \& Webster 10

Stone \& Webster 17

Bechtel 9 
Reactor Trips Counted by Plant

(with Associated NSSS Vendors and by A/E Firms

Plant Name
Susquehanna 2
Three Mile Island 1
Trojan
Turkey Poin. 3
Turkey Point 4
Vermont Yankee
Vogtle 1
WpPss 2
Waterford 3
Wolf Creek 1
Yankee-Rowe
Zion 1
Zion 2

NSSS Vendors

A/E Firms

No. of Trips

GE

$B \& H$

$H$

$H$

$H$

GE

U

GE

CE

H

H

H

W

Bechtel

10

Gilbert

Bechtel

Bechtel.

Bechtel

Ebasco

Bechtel

Burns \& Roe

Ebasco

Bechtel and Sargent \& Lundy

Stone \&' Webster

Sargent \& Lundy

Sergent \& Lundy

10

12

17

13

8

21

30

27

24

9

14

11

Total No. of Trips:

1405 


\section{APPENDIX I}

BOP Trips as a Function of Power Leve1 
Listing of Reactor Trips by Power Level

\begin{tabular}{|c|c|c|c|c|c|c|}
\hline Plant Name & $0-5 \%$ & $5-25 x$ & $25 \cdot 50 x$ & $50-75 \%$ & $75-100 x$ & Total \\
\hline Arkansas Nuclear one - 1 & 0 & 3 & 2 & 1 & 8 & 14 \\
\hline Arkansas Nuclear One -2 & 2 & 1 & 0 & 1 & 8 & 12 \\
\hline Beaver Valley 1 & 0 & 4 & 2 & 0 & 8 & 14 \\
\hline Beaver Valley 2 & 0 & 2 & 1 & 3 & 6 & 12 \\
\hline Big Rock Point & 1 & 4 & 0 & 0 & 1 & 6 \\
\hline Braidwood 1 & 3 & 1 & 2 & 0 & 3 & 9 \\
\hline Braidwood 2 & 2 & 3 & 2 & 1 & 2 & 10 \\
\hline Browns Ferry 1 & 1 & 1 & 0 & 0 & 2 & 4 \\
\hline Browns Ferry 2 & 0 & 0 & 0 & 1 & 0 & 1 \\
\hline Browns Ferry 3 & 1 & 0 & 1 & 0 & 1 & 3 \\
\hline Brunswick 1 & 1 & 0 & 3 & 1 & 6 & 11 \\
\hline Brunswick 2 & 1 & 0 & 0 & 2 & 5 & 8 \\
\hline Byron 1 & 0 & 7 & 4 & 0 & 9 & 20 \\
\hline Byron 2 & 1 & 5 & 1 & 0 & 6 & 13 \\
\hline Callaway 1 & 7 & 4 & 4 & 3 & 15 & 33 \\
\hline Calvert Cliffs 1 & 1 & 2 & 2 & 1 & 14 & 20 \\
\hline Calvert Cliffs 2 & 0 & 1 & 1 & 0 & 9 & 11 \\
\hline Catawbe 1 & 0 & 5 & 0 & 3 & 10 & 18 \\
\hline Catawba 2 & 1 & 7 & 4 & 2 & 7 & 21 \\
\hline Clinton 1 & 1 & 2 & 0 & 3 & 3 & 9 \\
\hline Connecticut Yankee & 1 & 0 & 1 & 1 & 7 & 10 \\
\hline Cook 1 & 1 & 2 & 0 & 2 & 5 & 10 \\
\hline Cook 2 & 5 & 3 & 0 & 1 & 9 & 18 \\
\hline Cooper & 1 & 2 & 3 & 3 & 4 & 13 \\
\hline Crystal River 3 & 1 & 4 & 0 & 3 & 6 & 14 \\
\hline Davis Besse & 2 & 1 & 4 & 1 & 5 & 13 \\
\hline Diablo Canyon 1 & 1 & 6 & 5 & 1 & 5 & 18 \\
\hline Diablo Canyon 2 & 0 & 5 & 7 & 1 & 8 & 21 \\
\hline Dresden 2 & 3 & 0 & 2 & 2 & 7 & 14 \\
\hline Dresden 3 & 2 & 4 & 3 & 1 & 12 & 22 \\
\hline Duane Arnold & 1 & 0 & 0 & 1 & 3 & 5 \\
\hline Farley 1 & 0 & 1 & 1 & 0 & 8 & 10 \\
\hline Farley 2 & 0 & 2 & 1 & 1 & 3 & 7 \\
\hline Fermi 2 & 8 & 7 & 3 & 1 & 1 & 20 \\
\hline Fitzpatrick & 0 & 2 & 1 & 2 & 8 & 13 \\
\hline Fort Calhoun 1 & 0 & 0 & 0 & 0 & 1 & 1 \\
\hline Girna & 2 & 1 & 1 & 0 & 7 & 11 \\
\hline Grand Gulf 1 & 3 & 4 & 1 & 8 & 11 & 27 \\
\hline Hatch 1 & 0 & 1 & 1 & 3 & 10 & 15 \\
\hline Hatch 2 & 1 & 1 & 3 & 0 & 13 & 18 \\
\hline Hope C'reek 1 & 3 & 1 & 1 & 1 & 10 & 16 \\
\hline Indian Point 2 & 5 & 4 & 3 & 1 & 10 & 23 \\
\hline Indian Point 3 & 2 & 5 & 1 & 3 & 15 & 26 \\
\hline Kewaunee & 4 & 4 & 0 & 2 & 6 & 16 \\
\hline LaSalle 1 & 1 & 0 & 1 & 6 & 8 & 16 \\
\hline LaSalle 2 & 1 & 2 & 1 & 3 & 6 & 13 \\
\hline Limerick & 1 & 0 & 1 & 0 & 3 & 5 \\
\hline Maine Yankee & 1 & 6 & 0 & 5 & 13 & 25 \\
\hline McGuire 1 & 0 & 0 & 0 & 2 & 9 & 11 \\
\hline
\end{tabular}


Listing of Reactor Trips by Power Level

\begin{tabular}{|c|c|c|}
\hline Plant Name & $0.5 \%$ & $5-25 \%$ \\
\hline McGuire 2 & 0 & 3 \\
\hline Millstone 1 & 1 & 1 \\
\hline Millstone 2 & 0 & 2 \\
\hline Millstone 3 & 0 & 10 \\
\hline Monticello & 1 & 0 \\
\hline Nine Mile Point 1 & 3 & 1 \\
\hline Nine Mile Point 2 & 3 & 1 \\
\hline North Anna 1 & 0 & 4 \\
\hline North Anne 2 & 1 & 0 \\
\hline Oconee 1 & 0 & 1 \\
\hline Oconee 2 & 0 & 0 \\
\hline Oconee 3 & 0 & 2 \\
\hline Oyster Creek & 3 & 1 \\
\hline Palisades & 0 & 0 \\
\hline Palo Verde 1 & 1 & 3 \\
\hline Palo Verde 2 & 0 & 2 \\
\hline Peach Bottom 2 & 1 & 0 \\
\hline Peach Bottom 3 & 3 & 0 \\
\hline Perry 1 & 3 & 1 \\
\hline Pilgrim & 1 & 2 \\
\hline Point Beach 1 & 0 & 0 \\
\hline Point Beach 2 & 1 & 0 \\
\hline Piairie Island 1 & 1 & 2 \\
\hline Prairle 1 sland 2 & 0 & 0 \\
\hline Quad Cities 1 & 1 & 1 \\
\hline Quad Cities 2 & 1 & 0 \\
\hline Rancho Seco & 0 & 3 \\
\hline River Bend 1 & 6 & 3 \\
\hline Robinson 2 & 1 & 4 \\
\hline Salem 1 & 0 & 3 \\
\hline Salem 2 & 3 & 7 \\
\hline San Onofre 1 & 0 & 0 \\
\hline San Onofre 2 & 1 & 0 \\
\hline San Onofre 3 & 0 & 2 \\
\hline Sequoyah 1 & 0 & 1 \\
\hline Sequoyah 2 & 0 & 4 \\
\hline Shearon Harris 1 & 1 & 3 \\
\hline Shoreham & 1 & 0 \\
\hline South Texas 1 & 0 & 1 \\
\hline St. Lucie 1 & 1 & 2 \\
\hline St. Lucie 2 & 0 & 6 \\
\hline summer 1 & 0 & 6 \\
\hline Surry 1 & 0 & 4 \\
\hline surry 2 & 1 & 8 \\
\hline Susquehanna 1 & 0 & 1 \\
\hline Susquehanna 2 & 2 & 0 \\
\hline Three Mile Island 1 & 1 & 3 \\
\hline Trojan & 0 & 1 \\
\hline Turkey Point 3 & 1 & 2 \\
\hline
\end{tabular}

$25.50 \% \quad 50.75 \% \quad 75 \cdot 100 \% \quad$ Total

$\begin{array}{llll}1 & 0 & 23 & 27\end{array}$

23
5

$7 \quad 11$

922

68

610

$3 \quad 15$

$12 \quad 16$

$5 \quad 7$

59

79

49

$6 \quad 11$

39

$\begin{array}{ll}7 & 17\end{array}$

49

48

$7 \quad 13$

213

26

$3 \quad 3$

23

25

11

37

$9 \quad 11$

$4 \quad 11$

522

$6 \quad 15$

$13 \quad 19$

13

33

$9 \quad 11$

$7 \quad 10$

46

$5 \quad 11$

921

$\begin{array}{ll}0 & 1\end{array}$

$8 \quad 12$

$10 \quad 20$

$11 \quad 19$

$5 \quad 10$

$7 \quad 17$

59

510

$5 \quad 10$

$8 \quad 12$

Turkey Point 3

$9 \quad 17$ 
Listing of Reactor Trips by Power Level

$\begin{array}{lcccrrr}\text { Plant Name } & \mathbf{0 - 5 \%} & \mathbf{5 - 2 5 \%} & \mathbf{2 5 - 5 0 \%} & \mathbf{5 0 - 7 5 \%} & \mathbf{7 5 - 1 0 0 \%} & \text { Total } \\ \text { Yurkey Point 4 } & 0 & 1 & 1 & 0 & 11 & 13 \\ \text { Vermont Yankee } & 1 & 2 & 0 & 0 & 5 & 8 \\ \text { Vogtle 1 } & 2 & 5 & 1 & 0 & 13 & 21 \\ \text { Wppss 2 } & 3 & 13 & 6 & 2 & 6 & 30 \\ \text { Waterford 3 } & 2 & 8 & 0 & 3 & 14 & 27 \\ \text { Wolf Creek 1 } & 3 & 4 & 4 & 1 & 12 & 24 \\ \text { Yankee-Rowe } & 2 & 0 & 0 & 1 & 6 & 9 \\ \text { Zion 1 } & 3 & 4 & 2 & 1 & 4 & 14 \\ \text { Zion 2 } & 4 & 3 & 0 & 0 & 4 & 11 \\ \text { Total No. of Trips: } & 137 & 261 & 148 & 148 & 711 & 1405\end{array}$




\section{APPENDIX J}

Supplemental Data Base

Plant Design Data 
LISTING OF OPERATING NUCI.EAR POWER PLANTS

\begin{tabular}{|c|c|c|c|c|c|}
\hline NAME OF PLANT & OL DATE & POWER & NSSS & $A / E$ & $T / G M F G$. \\
\hline Arkansas Nuclear One 1 & $12 / 01 / 74$ & 836 & $B \& W$ & Bechtel & $W$ \\
\hline Arkansas Nuclear One 2 & $07 / 18 / 78$ & 858 & CE & Bechte1 & $G E$ \\
\hline Beaver Valley 1 & $01 / 30 / 76$ & 810 & W & $\begin{array}{l}\text { Duquesne } \\
\text { Llght \& } \\
\text { Stone \& } \\
\text { Webst }\end{array}$ & $W$ \\
\hline Beaver Valley 2 & $08 / 01 / 87$ & 830 & $W$ & $\begin{array}{l}\text { Duquesne } \\
\text { Light/Stone } \\
\text { \& Webster }\end{array}$ & W \\
\hline Big Rock Point & $08 / 30 / 62$ & 69 & GE & Bechtel & GE: \\
\hline Bratdwoud 1 & $05 / 21 / 87$ & 1120 & $W$ & $S \& L$ & $W$ \\
\hline Bratdwood 2 & $12 / 18 / 87$ & 1120 & $W$ & $\begin{array}{l}\text { Sargent \& } \\
\text { Lundy }\end{array}$ & W \\
\hline Browns Ferry 1 & $12 / 20 / 73$ & 1065 & GE & TVA & GE \\
\hline Browns Ferry 2 & $08 / 02 / 74$ & 1065 & GE & TVA & GE \\
\hline Browns Ferry 3 & $08 / 18 / 76$ & 1065 & GE & TVA & GE \\
\hline Brunswick 1 & $11 / 12 / 76$ & 790 & GE & $\begin{array}{l}\text { Untted } \\
\text { Engineers }\end{array}$ & GE \\
\hline Brunswick 2 & $12 / 27 / 74$ & 790 & GE & $\begin{array}{l}\text { United } \\
\text { Engineers }\end{array}$ & $G E$ \\
\hline Byron 1 & $02 / 14 / 85$ & 1120 & $W$ & $S \& L$ & $W$ \\
\hline Byron 2 & $01 / 30 / 87$ & 1120 & $W$ & $S \& L$ & $W$ \\
\hline Callaway 1 & $06 / 11 / 84$ & 1150 & $W$ & Bechtel & GE \\
\hline Calvert Cliffs 1 & $07 / 31 / 74$ & 845 & $C E$ & Bechtel & GE \\
\hline Calvert Cliffs 2 & $08 / 13 / 76$ & 845 & $C E$ & Bechtel & W \\
\hline
\end{tabular}


LISTING OF OPERATING NUCLEAR POWER PLANTS

\begin{tabular}{|c|c|c|c|c|c|}
\hline NAME OF PLANT & OL. DATE & POWER & NSSS & $A / E$ & $T / G M F G$. \\
\hline Catawba 1 & $06 / 01 / 85$ & 1145 & W & $\begin{array}{l}\text { Duke Power } \\
\text { Company }\end{array}$ & GE \\
\hline Catawba 2 & $05 / 01 / 86$ & 1145 & W & $\begin{array}{l}\text { Duke Power } \\
\text { Company }\end{array}$ & GE: \\
\hline clinton 1 & $04 / 17 / 87$ & 950 & GE & $\begin{array}{l}\text { Sargent \& } \\
\text { Lundy }\end{array}$ & GE \\
\hline Connectfcut Yankee & $06 / 30 / 67$ & 582 & $W$ & $\begin{array}{l}\text { Stone \& } \\
\text { Webster }\end{array}$ & W \\
\hline Cook 1 & $10 / 25 / 74$ & 1030 & $W$ & $\begin{array}{l}\text { Amertcan } \\
\text { Electrtc } \\
\text { Power }\end{array}$ & $\mathrm{GE}$ \\
\hline Cook 2 & $12 / 23 / 77$ & 1100 & W & $\begin{array}{l}\text { Amertcan } \\
\text { Electrtc } \\
\text { Power }\end{array}$ & Brown Bover \\
\hline Cooper & $01 / 18 / 74$ & 778 & GE & Burns \& Roe & $W$ \\
\hline Crystal River 3 & $12 / 03 / 76$ & 837 & $B \& W$ & Gtlbert & W \\
\hline Davis Besse & $04 / 22 / 77$ & 906 & $B \& W$ & Bechtel & GE. \\
\hline Diablo Canyon 1 & $09 / 22 / 81$ & 1086 & W & $\begin{array}{l}\text { Paciftc Gas } \\
\text { \& Electric }\end{array}$ & W \\
\hline Diablo Canyon 2 & $08 / 26 / 85$ & 1119 & W & $\begin{array}{l}\text { Pactflc Gas } \\
\text { and Electictc }\end{array}$ & W \\
\hline Dresden 2 & $12 / 22 / 69$ & 794 & GE & $\begin{array}{l}\text { Sargent \& } \\
\text { Lundy }\end{array}$ & GE \\
\hline Dresden 3 & $01 / 12 / 71$ & 794 & $\mathrm{GE}$ & $\begin{array}{l}\text { Sargent \& } \\
\text { Lundy }\end{array}$ & GE \\
\hline Duane Arnold & $02 / 22 / 74$ & 538 & $\mathrm{GE}$ & Bechtel & GE \\
\hline Farley 1 & $06 / 25 / 77$ & 829 & W & $\begin{array}{l}\text { Southern } \\
\text { Company and } \\
\text { Bechtel }\end{array}$ & W \\
\hline
\end{tabular}


LISTING OF OPERATING NUCIEAR POWER PIIANTS

NAME OF PLANT

Farley 2

fermt?

Fltzpatrick

Fort Calhoun

Gitnna

Grand Gulf 1

Hatch 1

Hatch 2

Hipe Creek 1

Indian Point 2

Indian Point 3

Kewaunee

La Crosse

La Salle 1

La Salle 2
OL DATE POWER NSSS

$10 / 23 / 80 \quad 829 \mathrm{~W}$

03/20/85 1093 GE

$10 / 17 / 74 \quad 816 \mathrm{GE}$

05/24/73 492 CE

$09 / 19 / 69 \quad 470 \mathrm{~W}$

07/01/82 1250 GE

08/06/74 786 GE

06/13/78 795 GE

07/26/86 1067 GE

$09 / 28 / 73$

$873 \mathrm{~W}$

$12 / 12 / 75 \quad 965 \mathrm{~W}$

$12 / 21 / 73 \quad 535 \mathrm{~W}$

$11 / 01 / 69$

50 Allis Chalmer

04/17/82 1078 GE

12/16/83 1078 GE

$S \& 1$

Fluor

Ploneer

H 111

Qtlbert

Bechtel

Allis-Chalmers

Southern

GE

Company and

Bechtel

Southern

Company and

Bechte1

GE

Bechtel GE

Untted

Erigtneers

United

Engineers

$W$

Sargent \&

Allts Chalmers Lundy

$S \& L \quad G E$

GE 
LISTING OF OPERATING NUCLEAR POWER PLANTS

\begin{tabular}{|c|c|c|c|c|c|}
\hline NAME OF PLANT & OL. DATE & POWER & NSSS & $A / E$ & $T / G M I$ \\
\hline Limertck & $10 / 26 / 84$ & $1055 G$ & $G E$ & Bechtel & $\mathrm{GE}$ \\
\hline Matne Yankee & $06 / 01 / 73$ & $825 \mathrm{C}$ & $C E$ & $\begin{array}{l}\text { Stone \& } \\
\text { Webster }\end{array}$ & W \\
\hline Mcgutre 1 & $06 / 29 / 81$ & $1180 \mathrm{~W}$ & W & $\begin{array}{l}\text { Duke Power } \\
\text { Company }\end{array}$ & W \\
\hline Mcgutre 2 & $03 / 01 / 83$ & $1180 \mathrm{~W}$ & W & $\begin{array}{l}\text { Duke Power } \\
\text { Company }\end{array}$ & W \\
\hline Millstone 1 & $10 / 07 / 70$ & $660 \mathrm{G}$ & $G E$ & Ebasco & GE \\
\hline M+11stone 2 & $08 / 01 / 75$ & $870 \mathrm{C}$ & $C E$ & Bechtel & GE \\
\hline Mll1stone 3 & $01 / 31 / 86$ & $1150 \mathrm{~W}$ & W & $\begin{array}{l}\text { Stone \& } \\
\text { Webster }\end{array}$ & GE \\
\hline Monticello & $09 / 08 / 70$ & $536 \mathrm{G}$ & $\mathrm{GE}$ & Bochtel & GE \\
\hline Nine Mile Point 1 & $08 / 22 / 69$ & $610 G$ & $G E$ & $\begin{array}{l}\text { Ntagara } \\
\text { Mohawk Power } \\
\text { Corp. }\end{array}$ & GE \\
\hline Nine Mile Point 2 & $10 / 31 / 86$ & $1080 G$ & GE & $\begin{array}{l}\text { Stone \& } \\
\text { Webster }\end{array}$ & $\mathrm{GE}$ \\
\hline North Anna 1 & $11 / 26 / 77$ & $915 \mathrm{~K}$ & W & $\begin{array}{l}\text { Stone \& } \\
\text { Webster }\end{array}$ & W \\
\hline North Anna 2 & $08 / 21 / 80$ & $915 \mathrm{k}$ & W & $\begin{array}{l}\text { Stone \& } \\
\text { Webster }\end{array}$ & W \\
\hline Oconee 1 & $02 / 06 / 73$ & 860 & $B \& W$ & $\begin{array}{l}\text { Duke and } \\
\text { Bechtel }\end{array}$ & GE \\
\hline Oconee 2 & $10 / 06 / 73$ & 860 & $B \& W$ & $\begin{array}{l}\text { Duke and } \\
\text { Bechtel }\end{array}$ & GE \\
\hline Oconee 3 & $07 / 19 / 74$ & 860 & $B \& W$ & $\begin{array}{l}\text { Duke and } \\
\text { Bechtel }\end{array}$ & GE \\
\hline Oyster Creek & $04 / 09 / 69$ & 620 & GE. & $\begin{array}{l}\text { Burns \& Roe } \\
\text { and GE - TUR }\end{array}$ & $\begin{array}{l}\text { GE } \\
\text { RKKEY । }\end{array}$ \\
\hline
\end{tabular}


LISTING OF OPERATING NUCLEAR POWER PLANTS

NAME OF PLANT

Paltsades

Palo Verde 1

Palo Verde 2

Palo Verde 3

Peach Bottom 2

Peach Bottom 3

Perry 1

Pilgrim

Point Beach 1

Point Beach 2

Pratrie Island 1

Pratrie Island 2

Quad Cities 1

quad cities 2

Rancho Seco

River Bend 1

Robinson 2

Salem 1

Salem 2
OL. DATE POWER NSSS

10/01/72 $777 \mathrm{CE}$

12/31/84 $1270 \mathrm{CE}$

12/09/85 $1270 \mathrm{CE}$

03/25/87 $1270 \mathrm{CE}$

08/08/73 $1065 \mathrm{GE}$

07/02/74 1065 GE

03/18/86 $1205 \mathrm{GE}$

06/08/72 $670 \mathrm{GE}$

$10 / 05 / 70 \quad 497 \mathrm{~W}$

$05 / 25 / 72 \quad 497 \mathrm{~W}$

$08 / 09 / 73 \quad 520 \mathrm{~W}$

$10 / 29 / 74 \quad 520 W$

10/01/71 789 GE

04/06/72 $789 \mathrm{GE}$

$08 / 16 / 74 \quad 916 B \& W$

$11 / 20 / 85 \quad 940 \mathrm{GE}$

$09 / 23 / 70 \quad 665 W$

$04 / 06 / 77 \quad 1090 \mathrm{~W}$

$08 / 18 / 81 \quad 1115 W$
$A / E$

$T / G M F G$.

Bechtel W

Bechtel GE

Bechtel GE

Bechtel GE

Bechtel GE

Bechtel GE

allbert $\quad G E$

Bechtel GE

Bechtel $W$

Bechtel W

Fluor $\quad W$

Ptoneer

Fluor

Ploneer

$S \& L$

GE

$S \& L \quad G E$

Bechtel $W$

Stone \& GE Webster

Ebasco

Public

Service

Electric \&

Gas

Publ ic

Service 
LISTING OF OPERATING NUCLEAR POWER PLANTS

\begin{tabular}{|c|c|c|c|c|}
\hline NAME OF PLANT & OL DATE & POWER & $A / E$ & $T / G M F G$. \\
\hline San Onofre 1 & $03 / 27 / 67$ & $436 \mathrm{~W}$ & Bechtel & W \\
\hline San Onofre 2 & $09 / 07 / 82$ & $1070 \mathrm{CE}$ & Bechtel & $\begin{array}{l}\text { GEC Turbine } \\
\text { Generators, } \\
\text { Ltd. }\end{array}$ \\
\hline San Onofi: 3 & $09 / 16 / 83$ & $1080 \mathrm{CE}$ & Bechtel & $\begin{array}{l}\text { GEC Turbine } \\
\text { Generators, } \\
\text { Ltd. }\end{array}$ \\
\hline Sequoyah 1 & $09 / 17 / 80$ & $1148 W$ & TVA & $W$ \\
\hline Sequoyah 2 & $09 / 15 / 81$ & $1148 \mathrm{~W}$ & TVA & $W$ \\
\hline Shearon Harris 1 & $01 / 12 / 87$ & $860 \mathrm{~W}$ & Ebasco & $W$ \\
\hline Shoreham & $12 / 31 / 99$ & $809 \mathrm{GE}$ & $\begin{array}{l}\text { Stone \& } \\
\text { Webster }\end{array}$ & $\mathrm{GE}$ \\
\hline South Teyas 1 & $03 / 22 / 88$ & $1250 \mathrm{~W}$ & Bechtel & $W$ \\
\hline St Lucie 1 & $03 / 01 / 76$ & $810 \mathrm{CE}$ & Ebasco & $W$ \\
\hline St. Lucie 2 & $04 / 06 / 83$ & $810 \mathrm{CE}$ & Ebasco & $W$ \\
\hline Summer 1 & $08 / 06 / 82$ & $900 \mathrm{~W}$ & Gilbert & GE \\
\hline Surry 1 & $05 / 25 / 72$ & $781 \mathrm{~W}$ & $\begin{array}{l}\text { Stone \& } \\
\text { Webster }\end{array}$ & $W$ \\
\hline Surry 2 & $01 / 29 / 73$ & $781 \mathrm{~W}$ & $\begin{array}{l}\text { Stone \& } \\
\text { Webster }\end{array}$ & $W$ \\
\hline Susquehanna 1 & $07 / 17 / 82$ & $1050 \mathrm{GE}$ & Bechtel & $\mathrm{GE}$ \\
\hline Susquehanna 2 & $03 / 23 / 84$ & $1050 \mathrm{GE}$ & Bechtel & $G E$ \\
\hline Three Mile Island 1 & $04 / 19 / 74$ & 792 B \& W & Gilbert & GE \\
\hline Trojan & $11 / 21 / 75$ & $1130 \mathrm{~W}$ & Bechtel & CF \\
\hline Turkey Point 3 & $07 / 19 / 72$ & $728 \mathrm{~W}$ & Bechtel & $W$ \\
\hline Turkey Point 4 & $04 / 10 / 73$ & $728 \mathrm{~W}$ & Bechtel & $W$ \\
\hline
\end{tabular}


LISTING OF OPERATING NUCLEAR POWER PLANTS

\begin{tabular}{|c|c|c|c|c|c|}
\hline NAME OF PLANT & OL DATE & POWER & NSSS & $A / E$ & $T / G M F G$. \\
\hline Vermont Yankee & $02 / 28 / 73$ & 514 & GE & Ebasco & SAL \\
\hline Vogtle 1 & $01 / 16 / 87$ & 1160 & $W$ & Bechtel & GE \\
\hline WPPSS 2 & $12 / 20 / 83$ & 1150 & GE & Burns \& Roe & $W$ \\
\hline Waterford 3 & $12 / 18 / 84$ & 1165 & CE & Ebasco & $W$ \\
\hline Wolf Creek & $03 / 11 / 85$ & 1150 & $W$ & $\begin{array}{l}\text { Bechtel and } \\
\text { Sargent \& } \\
\text { Lundy }\end{array}$ & GE \\
\hline Yankee-Rowe & $07 / 09 / 60$ & 175 & $W$ & $\begin{array}{l}\text { Stone \& } \\
\text { Webster }\end{array}$ & $W$ \\
\hline Zion 1 & $04 / 06 / 73$ & 1040 & $W$ & $S \& L$ & $W$ \\
\hline Zion 2 & $11 / 14 / 73$ & 1040 & $W$ & $S \& L$ & $W$ \\
\hline
\end{tabular}




\section{APPENDIX K}

Supplemental Data Base

Critical Hour Data 
Listing of Critical Hours for Each Plant During 1984 - 1988 Period

Plant Name

Arkansas Nuclear one - 1

Arkansas Nuclicar One - 2

Beaver Valley 1

Beaver Valley 2

Big Rock point

Braidwood 1

Braidwood 2

Browns Ferry 1

Browns Ferry 2

Browns Ferry 3

Brunswick 1

Brunswick 2

Byron 1

Byron 2

Callaway 1

Calvert Cliffs 1

Calver: Cliffs 2

Catawba 1

Catawba 2

clinton 1

Connecticut Yankee

Cook 1

Cook 2

Cooper

Crystal River 3

Davis Besse

Diablo Canyon 1

Diablo Canyon 2

Dresden 2

Dresden 3

Duane Arnold

Farley 1

Farley 2

Fermi 2

Fitzpatrick

Fort Calhoun 1

Ginna

Grand Gulf 1

Hatch 1

Hatch 2

Hope Creek 1

Indian Point 2

Indian Point 3

Kewaunee

LaSalle 1

Lasalle 2

Limerick

Maine Yankee
Critical Critical Critical Critical Critical 5-Yr Total Hours Hours Hours Hours Hours Critical $\begin{array}{llllll}1984 & 1985 & 1986 & 1987 & 1988 & \text { Years }\end{array}$

$\begin{array}{llllll}6222.4 & 7005.4 & 5536.5 & 7855.7 & 6156.60 & 3.70\end{array}$

$\begin{array}{lllllll}7631.9 & 6377.4 & 6370.0 & 7715.4 & 6032.00 & 3.89\end{array}$

$\begin{array}{lllllll}6476.3 & 8245.3 & 6243.8 & 7339.4 & 7066.70 & 4.13\end{array}$

$\begin{array}{llllll}0.0 & 0.0 & 0.0 & 965.5 & 8283.8 / 1 & 1.05\end{array}$

$\begin{array}{llllll}6981.9 & 6539.5 & 8387.3 & 6214.6 & 6394.21) & 3.94\end{array}$

$\begin{array}{llllll}0.0 & 0.0 & 0.0 & 3059.7 & 3510.4(1 & 0.75\end{array}$

$\begin{array}{llllll}0.0 & 0.0 & 0.0 & 0.0 & 1517.20 & 0.17\end{array}$

$\begin{array}{llllll}8067.4 & 1647.7 & 0.0 & 0.0 & 0.00 & 1.11\end{array}$

$\begin{array}{llllll}5895.7 & 0.0 & 0.0 & 0.0 & 0.00 & 0.67\end{array}$

$\begin{array}{llllll}700.7 & 1517.5 & 0.0 & 0.0 & 0.00 & 0.25\end{array}$

$\begin{array}{llllll}7023.8 & 3409.6 & 8317.6 & 5788.7 & 6660.70 & 3.56\end{array}$

$\begin{array}{lllllll}2650.1 & 7134.8 & 4232.4 & 8328.4 & 5645.80 & 3.19\end{array}$

$\begin{array}{llllll}0.0 & 1281.0 & 7820.9 & 6210.3 & 6485.10 & 2.49\end{array}$

$\begin{array}{llllll}0.0 & 0.0 & 0.0 & 2327.2 & 8676.00 & 1.25\end{array}$

$\begin{array}{llllll}302.5 & 8161.0 & 7306.6 & 6227.7 & 8202.10 & 3.44\end{array}$

$\begin{array}{llllll}7531.0 & 5367.6 & 6906.2 & 6615.5 & 6398.50 & 3.74\end{array}$

$\begin{array}{llllll}6630.2 & 6884.2 & 8443.0 & 5957.8 & 7827.10 & 4.08\end{array}$

$\begin{array}{llllll}0.0 & 3612.4 & 5425.2 & 6076.4 & 7070.30 & 2.53\end{array}$

$\begin{array}{llllll}0.0 & 0.0 & 1392.9 & 7212.8 & 6496.80 & 1.72\end{array}$

$\begin{array}{llllll}0.0 & 0.0 & 0.0 & 898.3 & 7399.40 & 0.94\end{array}$

$\begin{array}{llllll}6515.6 & 8682.4 & 5060.9 & 4728.9 & 6177.00 & 3.55\end{array}$

$\begin{array}{lllllll}8085.9 & 2595.6 & 7536.4 & 6000.6 & 8433.80 & 3.72\end{array}$

$\begin{array}{llllll}5294.8 & 5948.8 & 5560.5 & 6283.1 & 2715.50 & 2.94\end{array}$

$\begin{array}{llllll}5952.6 & 2057.5 & 6570.1 & 8424.2 & 5967.90 & 3.30\end{array}$

$\begin{array}{lllllll}8346.5 & 4385.3 & 3691.4 & 5333.6 & 7457.30 & 3.33\end{array}$

$\begin{array}{lllllll}5529.0 & 2846.6 & 178.0 & 742.5 .7 & 2126.70 & 2.06\end{array}$

$\begin{array}{llllll}967.0 & 5295.6 & 5967.4 & 8475.7 & 5682.30 & 3.01\end{array}$

$\begin{array}{llllll}0.0 & 1361.0 & 6857.0 & 6058.8 & 6190.70 & 2.33\end{array}$

$\begin{array}{llllll}6511.4 & 4961.6 & 7110.1 & 5763.7 & 6974.90 & 3.57\end{array}$

$\begin{array}{llllll}3889.0 & 6718.8 & 2756.8 & 7208.7 & 6346.30 & 3.07\end{array}$

$\begin{array}{llllll}6627.1 & 4733.2 & 7350.2 & 5668.3 & 6609.90 & 3.53\end{array}$

$\begin{array}{lllllll}7005.8 & 7504.1 & 7276.4 & 8307.2 & 7428.30 & 4.28\end{array}$

$\begin{array}{lllllll}8375.7 & 6888.1 & 7549.7 & 6537.7 & 8784.00 & 4.35\end{array}$

$\begin{array}{lllllll}0.0 & 0.0 & 869.8 & 5147.8 & 5022.50 & 1.26\end{array}$

$\begin{array}{llllll}7087.2 & 5799.6 & 8075.8 & 6161.3 & 6060.60 & 3.78\end{array}$

$\begin{array}{llllll}5386.3 & 6466.1 & 8485.2 & 6608.3 & 6510.00 & 3.82\end{array}$

$\begin{array}{lllllll}6848.7 & 7838.5 & 7716.7 & 8014.5 & 7679.20 & 4.34\end{array}$

$\begin{array}{lllllll}1010.1 & 2883.4 & 5624.6 & 7203.3 & 8498.10 & 2.88\end{array}$

$\begin{array}{lllllll}5638.7 & 6907.5 & 5521.2 & 7191.7 & 6008.80 & 3.57\end{array}$

$\begin{array}{lllllll}3108.7 & 7373.1 & 6451.7 & 8599.6 & 6359.20 & 3.63\end{array}$

$\begin{array}{llllll}0.0 & 0.0 & 2037.9 & 7570.1 & 7089.50 & 1.90\end{array}$

$\begin{array}{llllll}4718.4 & 8504.1 & 5101.7 & 6347.3 & 7492.10 & 3.67\end{array}$

$\begin{array}{lllllll}6941.6 & 5901.1 & 6581.6 & 5496.5 & 7312.70 & 3.68\end{array}$

$\begin{array}{lllllll}7570.5 & 7266.5 & 7584.3 & 7860.9 & 7755.60 & 4.34\end{array}$

$\begin{array}{llllll}6280.0 & 5757.5 & 2396.6 & 5609.1 & 5931.10 & 2.96\end{array}$

$\begin{array}{lllllll}1611.8 & 3777.6 & 6613.9 & 4781.4 & 6648.20 & 2.67\end{array}$

$\begin{array}{llllll}0.0 & 3420.1 & 6717.0 & 6127.0 & 8476.30 & 2.92\end{array}$

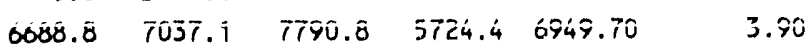


Listing of Critical Hours for Each Plant During 1984 - 1988 Period

Plant Name

McGuire 1

McGuire 2

Millstone 1

Millstone 2

Millstone 3

Mont icello

Nine Mile Point 1

Nine Mile Point 2

North Anne 1

North Anna 2

Oconee 1

Oconee 2

Oconee 3

Oyster Creek

Pal isades

Palo Verde 1

Palo Verde 2

Palo Verde 3

Peach Bottom 2

Peach Bottom 3

Perry 1

Pilgrim

Point Beach 1

Point Beach 2

Prairie Island 1

Prairie Island 2

Quad Cities 1

Quad Cities 2

Rancho Seco

River Bend 1

Robinson 2

Salem 1

Salem 2

San Onofre 1

San Onofre 2

San Onofre 3

Sequoyah 1

Sequoyah 2

Shearon Harris 1

South Texas 1

st. Lucie 1

st. Lucie 2

sumner 1

surry 1

surry 2

Susquehanna 1

Susquehanna 2

Three Mile Island 1

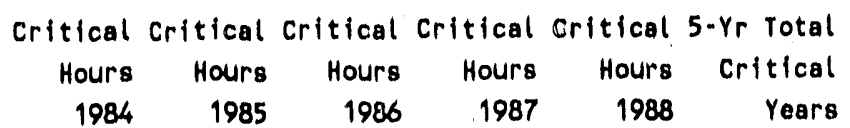

$\begin{array}{llllll}6090.8 & 6842.4 & 5022.2 & 6835.7 & 6783.80 & 3.60\end{array}$

$\begin{array}{llllll}6138.3 & 5490.5 & 5770.4 & 7046.9 & 7313.50 & 3.62\end{array}$

$\begin{array}{llllll}6990.2 & 7324.4 & 8276.5 & 6970.7 & 8661.60 & 4.36\end{array}$

$\begin{array}{llllll}8596.8 & 4460.7 & 6599.6 & 8242.0 & 6953.10 & 3.97\end{array}$

$\begin{array}{llllll}0.0 & 0.0 & 5412.8 & 6350.7 & 7196.30 & 2.16\end{array}$

$\begin{array}{llllll}810.6 & 8163.0 & 6984.9 & 7173.6 & 8768.70 & 3.64\end{array}$

$\begin{array}{llllll}6414.0 & 8524.0 & 5823.5 & 8171.2 & 0.00 & 3.30\end{array}$

$\begin{array}{llllll}0.0 & 0.0 & 0.0 & 1638.9 & 2982.30 & 0.53\end{array}$

$\begin{array}{llllll}4759.9 & 6938.8 & 7560.0 & 4585.4 & 8019.50 & 3.63\end{array}$

$\begin{array}{llllll}6136.0 & 8534.4 & 7301.3 & 6842.2 & 8734.90 & 4.28\end{array}$

$\begin{array}{lllllll}7452.4 & 8453.3 & 5948.7 & 6913.9 & 8769.00 & 4.28\end{array}$

$\begin{array}{llllll}8784.0 & 6740.3 & 7253.7 & 8604.9 & 6989.20 & 4.38\end{array}$

$\begin{array}{llllll}6520.7 & 6140.9 & 7835.4 & 6142.2 & 7229.70 & 3.86\end{array}$

$\begin{array}{llllll}1700.0 & 6818.5 & 2389.1 & 5620.0 & 5789.00 & 2.55\end{array}$

$\begin{array}{llllll}1550.5 & 7490.2 & 1490.5 & 4226.6 & 4990.40 & 2.25\end{array}$

$\begin{array}{llllll}0.0 & 2450.7 & 5112.5 & 4589.7 & 5762.90 & 2.04\end{array}$

$\begin{array}{llllll}0.0 & 0.0 & 2217.9 & 6984.2 & 5750.00 & 1.71\end{array}$

$\begin{array}{llllll}0.0 & 0.0 & 0.0 & 726.9 & 8201.70 & 1.02\end{array}$

$\begin{array}{llllll}2583.9 & 2910.6 & 7272.8 & 1729.8 & 0.00 & 1.65\end{array}$

$\begin{array}{lllllll}7757.7 & 4055.7 & 5929.6 & 1823.2 & 0.00 & 2.23\end{array}$

$\begin{array}{llllll}0.0 & 0.0 & 0.0 & 811.3 & 6939.10 & 0.88\end{array}$

$\begin{array}{llllll}170.3 & 8159.0 & 1715.5 & 0.0 & 0.30 & 1.15\end{array}$

$\begin{array}{llllll}6420.1 & 6974.4 & 7905.4 & 7389.4 & 7847.70 & 4.17\end{array}$

$\begin{array}{llllll}7544.2 & 7576.2 & 7262.7 & 7583.1 & 7707.80 & 4.30\end{array}$

$\begin{array}{llllll}8321.3 & 7363.2 & 7898.1 & 7287.6 & 7835.60 & 4.41\end{array}$

$\begin{array}{llllll}7844.0 & 7408.6 & 7972.1 & 8760.0 & 7813.90 & 4.54\end{array}$

$\begin{array}{llllll}4766.9 & 8339.0 & 6151.3 & 6251.6 & 8477.90 & 3.88\end{array}$

$\begin{array}{lllllll}6988.6 & 6361.8 & 6448.0 & 6941.4 & 6292.80 & 3.77\end{array}$

$\begin{array}{llllll}5338.8 & 2874.6 & 0.0 & 0.0 & 5543.80 & 1.57\end{array}$

$\begin{array}{llllll}0.0 & 0.0 & 4777.5 & 5995.1 & 8279.80 & 2.17\end{array}$

$\begin{array}{llllll}616.1 & 7859.8 & 7118.3 & 6354.3 & 5791.40 & 3.16\end{array}$

$\begin{array}{llllll}2672.3 & 8361.9 & 7097.2 & 6412.5 & 6937.10 & 3.59\end{array}$

$\begin{array}{llllll}3386.0 & 5231.2 & 5629.4 & 6423.0 & 5992.80 & 3.04\end{array}$

$\begin{array}{llllll}888.6 & 6783.8 & 2975.3 & 7382.9 & 3817.70 & 2.49\end{array}$

$\begin{array}{llllll}5272.4 & 5235.8 & 6479.1 & 6192.5 & 8286.30 & 3.59\end{array}$

$\begin{array}{llllll}4395.2 & 4789.9 & 7402.2 & 7135.2 & 5930.80 & 3.38\end{array}$

$\begin{array}{llllll}6206.1 & 3797.2 & 0.0 & 0.0 & 379.50 & 1.18\end{array}$

$\begin{array}{llllll}6334.0 & 5289.4 & 0.0 & 0.0 & 5202.10 & 1.92\end{array}$

$\begin{array}{llllll}0.0 & 0.0 & 0.0 & 4449.9 & 6585.10 & 1.26\end{array}$

$\begin{array}{llllll}0.0 & 0.0 & 0.0 & 0.0 & 2496.90 & 0.28\end{array}$

$\begin{array}{llllll}5555.2 & 7134.7 & 8424.0 & 6971.6 & 7554.30 & 4.06\end{array}$

$\begin{array}{lllllll}7379.2 & 7442.7 & 7326.7 & 7382.3 & 8784.00 & 4.37\end{array}$

$\begin{array}{llllll}5553.4 & 6439.9 & 8453.2 & 6222.4 & 6067.70 & 3.73\end{array}$

$\begin{array}{llllll}5293.7 & 7935.4 & 6233.2 & 6178.3 & 3755.20 & 3.35\end{array}$

$\begin{array}{llllll}7435.3 & 5936.5 & 6171.1 & 6555.2 & 5028.30 & 3.55\end{array}$

$\begin{array}{llllll}6549.3 & 5598.5 & 6196.3 & 6464.6 & 8289.70 & 3.77\end{array}$

$\begin{array}{llllll}2145.9 & 7121.2 & 5946.6 & 8484.0 & 6156.90 & 3.41\end{array}$

$\begin{array}{llllll}0.0 & 2084.8 & 6268.6 & 6435.2 & 6760.90 & 2.45\end{array}$ 
Listing of Critical Hours for Each Plant During 1984 - 1988 Period

Plant Name

Critical Critical Critical Critical Critical 5-Yr Total

Hours Hours Hours Hours Hours Critical

$\begin{array}{llllll}1984 & 1985 & 1986 & 1987 & 1988 & \text { Years }\end{array}$

Trojan

Turkey Point 3

Turkey Point 4

Vermont Yankee

Vogtle 1

WPPSS 2

Waterford 3

Wolf Creek 1

Yankee-Rowe

Zion 1

zion 2

$\star \star \star$ Total $\star \star \star *$

$\begin{array}{llllll}4895.4 & 6804.7 & 7064.1 & 4730.5 & 5925.30 & 3.36\end{array}$

$\begin{array}{llllll}7366.6 & 5405.0 & 6988.1 & 1909.7 & 5408.10 & 3.09\end{array}$

$\begin{array}{llllll}5079.8 & 7916.8 & 3048.1 & 4503.2 & 5050.10 & 2.92\end{array}$

$\begin{array}{llllll}7115.2 & 6297.2 & 4359.6 & 7374.6 & 8404.40 & 3.83\end{array}$

$\begin{array}{llllll}0.0 & 0.0 & 0.0 & 4048.1 & 6822.30 & 1.2 .4\end{array}$

$\begin{array}{llllll}416.5 & 6899.7 & 6391.5 & 6199.4 & 6310.90 & 2.99\end{array}$

$\begin{array}{llllll}0.0 & 1868.7 & 7011.6 & 7224.3 & 6624.50 & 2.59\end{array}$

$\begin{array}{llllll}0.0 & 2790.3 & 6523.6 & 6152.6 & 6117.60 & 2.46\end{array}$

$\begin{array}{llllll}6398.6 & 7598.3 & 8343.5 & 7248.2 & 7486.70 & 4.23\end{array}$

$\begin{array}{llllll}6319.8 & 5321.2 & 5491.0 & 6877.3 & 6723.90 & 3.50\end{array}$

$\begin{array}{llllll}6285.2 & 5909.2 & 7783.5 & 5569.7 & 7004.60 & 3.71\end{array}$

315.17 
APPENDIX L

Sources of Information 


\section{APPENDIX L \\ SOURCES OF INFORMATION}

This study of the safety significance of balance-of-plant systems fatlures drew upon a broad range of information sources. The primary source for quantitative analyses was the Licensee Event Report (LER) data base sponsored by NRC and currently maintained by Oak Ridge National Laboratory. The LER data base was used to develop a study data base of BOP-related reactor trips. The development and use of the BOP data base are described, respectively, in Sections 2 and 3 of the report.

In addition, the study included an extensive review of other studies and activities by the NRC, its contractors, and nuclear industry organizations. In this appendix, synopses are provided of the documents reviewed for the study. Summartes of activities that also served as information sources are also included.

The material presented in this appendix is organized in eight subsections:

1. NUREG Reports and Inspection Reports

2. Information Resulting from NRC Requirements and Requests

3. Unresolved Safety Issues and Generic Issues

4. Maintenance Rulemaking Activities

5. The Precursor Identification Program

6. ACRS Information and Meetings

7. AEOD Activities

8. Efforts by Utilities and Industry Groups.

\section{L.1 NUREG Reports and Inspection Reports}

Following are synopses of the NUREGs and Inspection Reports reviewed in preparation for the analyses conducted in this study.

NUREG-1115, "Categorization of Reactor Safety Issues from a Risk Perspective, " March 1985

NUREG-1115 reports on the results of a categorization and ranking of reactor safety issues based on risk considerations. With regard to the 
portions of the program relevant to BOP systemls, the risk-based importance ranking was generally consistent with importance ranking of data derived from Licensee Event Reports (LERs), 1.e., hardware fallures and human errors were highly ranked. Other tssue areas with high rankings were inttlating events, system responses, and accident sequence analysis.

NUREG-1206, "Analysis of French (Pa1ue1) Pressurtzed Water Reactor Design Differences Compared to Current U.S. PWR Designs, "June 1986

The NRC staff identified 25 differences between the French + design and the U.S. SNUPPS plant, of which four to six issues are perceived as BOP-related. Three issues have a "moderate" impact on safety significance: the capability to resupply the Condelsate Storage Tank, the use of self-cooled safety-related pumps, and the improvement in the $D C$ power supply system.

NUREG-1217, "Evaluation of Safety Implications of Control Systems in LWR Nuclear Power Plants; Technical Findings Related to Unresolved Safety Issue A-47," Draft Report for Comment, Apr 111988

NUREG-1217 reports the technical findings of an evaluation of Unresolved Safety Issue (USI) A-47 concerning the safety implications of control system failures in nuclear power plants. The report concludes that with the exception of the specific events stated below, transients or accidents resulting from or caused by control system fallures are less severe than, and therefore bounded by, the transients and accidents identified in the FSAR. The exceptions are reactor vessel (BWR) or steam generator (PWR) overf 111 events, core overheat events, and primary system overpressure events.

NRC recommendations for actions to deal with these events are given in a companion document, NUREG-1218, "Regulatory Analys is for Proposed Resolution of US I A-47, Safety Implications of Control Systems, "April 1988. An evaluation of the risk implications of control system fallures should therefore focus on the adequacy and implementation effectiveness of the actions recommended in NUREG-1218. 
NUREG-1218, "Regulatory Analysis for Proposed Resolution of USI A-47, Safety Implications of Control systems, "Draft report for Comment, Aprt1 1988

NUREG-1218 presents the regulatory analysis related to the proposed resolution of USI A-47, "Safety Imp1tcations of Control Systems." Technical findings regarding USI A-47 are given in NUREG-1217. A1though the scope of USI A-47 is quite large, the proposed resolution is quite 1 imtted, addressing primarily the need to improve protection against overfill events (steam generators for PWRs, reactor vessel for BWRs) for selected types of reactors.

Many of the events of interest to the BOP project relate to feedwater system fallures, but most of these are not overfill events. Thus, the resolution of USI A-47 is of 1 imited interest in the larger context of the risk implications of BOP failures.

NUREG-1272, "Report to the U.S. Nuclear Regulatory Commtsston on Analysis and Evaluation of Operational Data - 1986," May 1987

NUREG-1272 is the 1986 annual report of the NRC's Offtce of Analysis and Evaluation of Operational Data (AEOD). This NUREG covers a wide range of activities, some of which parallel the BOP project. These activities include the evaluation of initiating systems of plant trips that occurred during 1984-1986, which could be used to check the methods employed for the BOP study.

NUREG-1275, "Operating Experience Feedback Report - New Plants, " July 1987

Newly licensed commercial reactors have always exhibited a higher operational event frequency than mature plants. NUREG-1275 concludes that this behavior should not be accepted as inherent in the process of debugging a new plant. Early increased attention to operations, aggressive root cause analysis, enhanced training, and emphasis on BOP systems that have historically caused many events will significaitty reduce new plant trips, Emergency Safety Features actuations, and violations of Technical Specifications. 
NUREg/CR-3541, "Measures or the Risk Impacts of Testing and Maintenance Activities," November" 1983

No information of direct applifabllity to the BOP study was found. NUREG/CR-3568, "Handbook for Value-Impact Assessment," December 1983

No information of direct applicabilitiy to the BOP study was found.

NUREG/CR-3591, "Precursors to Potential Severe Core Damage Acctdents: 1980 1981, A Status Report," July 1984

An evaluation of about 8400 Licensee Event Reports for 1980-1981 was performed to evaluate precursors to potential severe core damage accidents. In general, reductions in the frequency and safety significance of initiating events were observed when compared to the 1969-1979 pertod whtch was prevtously analyzed. A signiftcant number of events were inltlated or exacerbated by fallures of BOP systems that could have resulted in severe core damage. This substantiates the importance of BOP systems in nuclear power plant safety.

NUREG/CR-3762, "Identffication of Equipment and Components Predicted as Stantficant Contributors to Severe Core Damage," May 1984

NUREG/CR-3762 describes work performed to tdentify equtpment and components whose fallure would make a significant contribution to severe core damage probabilities, based on predictive methods (probabilistic risk assessment) and performance data (Licensee Event Reports). The results are qualttative and not directly useful in developing quantitative data on the impact of BOP fatlures on safety systems.

NUREG/CR-3922, "Survey and Evaluation of System Interaction Events and Sources, " January 1985

NUREG/CR-3922 identiffes adverse system interactions from the body of documentation avatlable from the NRC and industry. From some 4000 
events during the years 1969 to 1983, 235 wore tdentffled as adverse system interactions; these were put in 23 categortes.

This document was prepared as the first phase of a project to tdentify and evaluate adverse system interactions for the Unresolved Safety Issue A-17, "Systems Interactions in Nuclear Power Plants." The document draws some conclustons about the characteristics of the resultant data, but provides no conclustons about systems interactions on the whole.

NUREG/CR-3958, "Effects of Control system Fallures on Translents, Accidents and Core-Melt. Frequenctes at a Combustion Engtneering Pressurtzed Water Reactor," March 1986

Paciflc Northwest Laboratory performed a study of the dominant control system fallure scenartos defined by Oak Ridge Nattonal Laboratory for the Calvert Cliffs-1 nuclear power plant. This study used an existing probabilistic risk assessment to evaluate the value or impact of proposed coirective actions in reducing public risk from these postulated ivents. Two of the three postulated events involve fallures in the main feedwater system, a BOP system. These events result in overflliting the steam generator with a potential main steam 1 ine break and steam generator tube rupture as consequences. The most promising corrective action to mitigate these events is a high steam generator level trip of the main feedwater pumps and/or feedwater block valves.

NUREG/CR-4103, "Uses of Human Reliablitty Analysis Probabilistic Risk Assessment Results to Resolve Personnel Performance Issues That Could Affect Safety," October 1985

No information provided in this report had direct relevance to the BOP study.

NUREG/CR-4281, "An Empirtcal Analysis of Selected Nuclear Power Plant Maintenance Factors and Plant Safety, "July 1985

NUREG/CR-4281 examines the relationship between five maintenance program attributes and the intermediate and final safety indicators. 
The five program attributes are related to the stze and organtzation of the maintenance program and the expertence of the top-level managers in the maintenance programs. The intermedtate safety indicators included the number of maintenance-related LERs, Systemattc Analysis of Licensee Performance (SALP) ratings, and the number of maintenance related instances of nuncompliance. The final safety indicators were al1 related to radiological releases and occupational exposures.

The study found a relationship between the maintenance program resources and the safety indicators. There was some indication that smaller, less hierarchical matntenance programs, with separate untts for mechanical, electrical, and instrumentation and control maintenance, result in better performance as rated by the intermedtate safety indicators. However, programs with combined mechanical, electrical, and instrumentation and control units tended to perform better when the final safety indicators were used.

The correlations found were not always as expected and in some cases were not in the direction expected. A possible explanation suggested by the authors is that the safety indicators may not have been complete. Suggested additions included maintenance-related trips and outages.

NUREG/CR-4314, "Brtef Survey and Compartson of Common Cause Fatlure Analysis," June 1985

NUREG/CR-4314 presents a summary of the methods and models avatlable for the evaluation of common cause and common mode fatlures. This report provides information on the general approaches to modeling common cause events, but does not deal with the causes of such events, nor does it address posstble solutions. The methods identified for common cause analysis include: bounding techniques, a Beta-factor model, a Binomial Fallure Rate model, a C-factor model, and common load models. Computer codes that can be used as aids to common cause analj'sis were also discussed. 
Recummendations for the improvement of common cause analysts techniques were presented:

- Develop a standard terminology.

- Develop crtterta for comparattve assessments of proposed methodologies.

- Develop credible data bases designed to answer the relevant estimation questions raised by system designers, performance analysts, and decision makers.

None of the methods summartzed in NUREG/CR-4314 was found to include all three of these features.

NUREG/CR-4372, "Probabilistic Risk Assessment (PRA) Appltcations," January 1986

NUREG/CR -4372 reports the results of a study to correlate system rellablilty insights from a specific PRA (Limerick Generating Station) with utflity survefllance programs and test procedures, and with NRC inspection procedures. A similar program could be performed to correlate PRA risk and rellablitty insights with ut 11 ity mainterlance and survelllance testing programs for BOP systems and components. Such a study would be one way of distinguishing BOP-related risk concerns from BOP-related rellabllity concerns. The results could also holp provide assurance that the utility maintenance and surveillance testing programs contain sufficlent detall to cover the more common fallure modes expected in BOP components and systems.

NUREG/CR-4385, "Effects of Control system Fallures on Transtents, Accidents and Core-Melt Frequenctes at a Westinghouse PWR," November 1985

Although a number of control system fallures (some involving the BOP) can lead to previously unanalyzed events with a risk of core-melt, the magnitude of this risk is small as compared to the overall plant risk. The relative magnitude of this risk is exaggerated due to the thherent conservatisms used for those areas in which there is considerable 
phenomenological uncertainty. The relative benefit of proposed corrective actions cannot be justified solely on value impact (i.e., cost-benefit). The role of the operator is crucial in reducing both the frequency and consequences of these events. The BOP components/systems were involved in steam generator overfilling and reactor coolant system (RCS) overcooling scenarios, but not in RCS overpressurization and steam generator tube rupture scenarios. The conclusions of the study pertain specifically to the Westinghouse PWR design and were obtained from modeling of the H.B. Robinson 2 power plant by the Idaho National Engineering Laboratory.

NUREG/CR-4386, Effects of Control System Failures on Transients, Accidents, and Core-Melt Frequencies at a Babcock and Wilcox Pressurized Water Reactor," December 1985

The relevance to the BOP project is in the analysis of the plant risk caused by failures of BOP systems and components such as main feedwater (MFW) pumps and valves, or the integrated control system (ICS).

For the steam generator overfill scenarios, the initiating event is postulated as a combination of an ICS failure that causes a feedwater increase and an undetected failure of the high-level MFW pump trip. The accident is then postulated to progress to a transient or a main steam line break event, which then results in a core-melt accident.

For the ICS-related power failures which lead to overfill and undercool events, two cases were identified: (1) loss of ICS hand power, and (2) loss of ICS auto power. For case 1 , it is assumed that continuous MFW pump operation at minimum speed would prevent operation of the emergency feedwater (EFW) system, since no trip signal would be generated. Steam generator dryout would occur unless the operatior manually initiated the EFW system within 30 minutes or high pressure injection within 60 minutes.

For case 2, the outcome depends on whether the operator detects the ICS auto power failure before an upset condition develops. If the operator detects the failure early enough, he or she will be able to control the event before the $p l a n t$ trips. If the condition is not detected, the 
plant will eventually trip due to perturbations in the system caused by the ICS power failure.

NUREG/CR-4387, "Effects of Control System Failures on Transients, Accidents, and Core-Melt Frequencies at a General Electric Boiling Water Reactor," December 1985

The relevance to the BOP project is in the analysis of the risk to the plant caused by BOP system failures such as condensate booster pump failures that cause reactor vessel overfill, and failures that initiate reactor vessel overfill and also defeat the high level feedwater trip.

The four failure modes leading to failure of level indication and the high level trip are all related to the water level sensors or sensor circuitry.

The failure modes associated with the condensate booster pump may be summarized as follows: any of the feedwater pump discharge valves, or their bypass valves, fails open; or the condenser bypass valve used to recirculate excess condensate flow back to the condenser fails closed.

NUREG/CR-4611, "Trends and Patterns in Maintenance Performance in the US Nuclear Power Industry 1980-1985," October 1986

NUREG/CR-4611 presents an analys is of maintenance performance in the US nuclear power industry for the years 1980 through 1985 . The analysis addressed the impact of maintenance practices, not the specifics of the programs that may cause the trends and patterns identified. The analys is focused on five performance categories that are directly influenced by the maintenance function: (1) overall system/component reliablitity, (2) overall safety system reliability, (3) challenges to safety systems, (4) radiological exposure, and (5) regulatory assessment. Trends and patterns over the 6-year period were explored. The mosit significant finding was that, although overall plant performance improved, the number and proportion of maintenance-related events increased. This was attributed to either a decrease in attention to this type of event by both the NRC and the nuclear industry or an actual decline in maintenance program effectiveness. 
The effects of BOP systems were not explicitly identified in this report. From the information provided in the report it is not possible to separate the impact of BOP maintenance programs from the impact of safety-related system maintenance programs.

NUREG/CR-4674, "Precursors to Potential Severe Core Damage Accidents: 1985 A Status Report," December 1986

of the 10 most serious severe accident precursor events identified in this study, several involved or were initiated by BOP systems/components:

- Failure of an electric pressure regulator resulted in the closure of a main steam isolation valve and reactor trip. Subsequent multiple failures resulted in equipment overheating, high reactor vessel water level, and loss of the isolation condenser function.

- Following a loss of power to safety-related buses, the failure of five check valves in the main feedwater system prevented auxiliary feedwater flow to the steam generators, caused a dainaging water hammer in the feedwater piping system, and resulted in an unisolatable leak in that system.

- An auxiliary transformer cooling system-initiated trip resuited in the temporary loss of all auxiliary feedwater.

- Several reactor trips initiated by loss of main feedwater were followed by further degradation due to failures in the auxiliary feedwater system, the reactor core isolation cooling system, or the high pressure cooling system.

NUREG/CR-4783, "Analys is of Balance of Plant Regulatory Issues, January $1987 "$

The information in this report was used widely in the BOP project, and is reflected throughout this report. 
The following NRC Inspection Reports and documents regarding inspections provided background information for the BOP study:

- Letter from R.M. Gallo, USNRC Region I, to C.A. McNei11, Jr., Senior Vice President - Nuclear, Public Service Electric and Gas Company, "Combined Inspection 50-272/87-18 and 50-311/87-20." (Salem 1 and 2), August 13, 1987.

- SECY-86-349, from V. Ste110, Jr., to the Commissioners, "Balance of Plant," November 21, 1986.

- Inspection and Enforcement Manual, Temporary Instruction 2515/83, "Balance of Plant Trial Inspection Program (Feedwater System)," February 26, 1987.

- Internal NRC memo from R.P. Correia to distribution, "BOP Initiated Trips Data," (undated) CIRCA late March 1987.

- Letter from A.R. Herdt, USNRC Region II, to J.P. O'Reilly, Senior Vice President - Nuclear Operations, Georgia Power Company, "NRC Special Inspection Team Reports Nos. 50-321/87-17 and 50-366/8717," (Hatch 1 and 2), September 2, 1987.

- Letter from J.J. Harrison, USNRC Region III, to C. Reed, Senior Vice President, Commonwealth Edison Company, (No Subject), (Re: Zion 1 and 2 BOP Inspection), November 25, $198 \%$.

- Letter from A.R. Herdt, USNRC Region II, to W.L. Stewart, Vice President, Virginia Power Company, "NRC Special Inspection Team Reports Nos. 50-280/88-02 and 50-281/88-02" (Surry 1 and 2), March 15,1988 .

\section{L.2 Information Resulting From NRC Requirements and Requests}

Information sources in this category are Generic Letters, Bulletins, and Notices. NRC Circuiars were not investigated in detail because they generally covered less significant issues and events, and the issuance of circulars was terminated in 1981 . 
Titles of Generic Letters, Bulletins, and Notices were reviewed to identify those with generic implications and potential relevance to the BOP study. Documents describing failures of specific pieces of BOP equipment or specific plant events were generally not selected for further review. Selected Generic Letters, Bulletins, and Notices were reviewed for input into the BOP project. Relevant documents are grouped by subject and summarized below. (Note: for Notices and Bulletins, the first iwo digits of the identification numbers indicate the year of issue.)

Electrical Systems - Failures/Problems (Information Notices 83-80, 84-76, $84-80,85-28,86-70$, and $87-24$ )

Electrical systern problems were expected to be a significant contributor to BOP challenges to safety systems. The Information Notices on this topic gave information on problems with inverters, lead acid batteries, non-nuclear instrument power, and elevated DC control voltage. As a result of these notices, some of the electrical problems have been resolved.

Instrument Air System Failures/Problems (Information Notices 81-38, 87-28, and 87-28 Supplement 1; Generic Letter 88-14)

Because of the number and persistence of instrument air problems, and because of their potential effects on safety systems, instrument air failures leading to reactor trips were flagged as an item of particular interest in the analysis of Licensee Event Reports performed during this study.

Human Error (Information Notices 84-58, 87-25)

Information Notices $84-58$ and 87-25 are devoted to human error as it appears in the so-called wrong unit, wrong train, or wrong component events. Between the two notices, 15 events are described, and reference is made to an $A E O D$ report which identified some 200 such events. Clearly, wrong unit, wrong train, and wrong component errors are relatively frequent, apply to both BOP and safety systems, and are a problem which could have serious ramifications. Human errors have 
been a recognized concern for some time, as evidenced by the two Generic Safety Issues on human factors.

Instrumentation and Controls (Information Notices 84-86, 85-51, and 85-89)

Information Notices 84-86, 85-51, and 85-89 cover three independent problems in the area of instrumentation and control: inadequate signal isolation, detrimental removal of fuses, and total loss of control room cooling. Of the three, only detrimental removal of fuses seems to have precedents and might be considered a generic problem. The other two incidents appear to have been isolated cases.

Six events of detrimental removal of fuses were reported to have occurred between 1981 and 1984. However, only one of the six of these human errors was on BOP equipment. This area does not seem to be a significant contributor to BOP challenges to safety systems.

Fire Protection (Information Notice 83-41)

Information Notice 83-41 describes 11 cases of fire suppression actuation causing inoperability of safety-related equipment and indicates that many other cases were reported. Additionally, the Notice extrapolates some of these events to more serious situations.

In spite of the fact that only one Information Notice has been issued on the subject, actuation of fire suppression systems can pose a serious and unpredictable challenge to safety systems. Because the systems interactions from sucil events are sometimes hard to identify before they occur, there are potentially many such problems existent yet undetected, many of which could challenge safety systems.

The thrust of the BOP study, however, was not to find system interactions; so, although the information in notice 83-41 is relevant, it is not applicable within the study scope. 
Information Notice 83-44, titled "Potential Damage to Redundant Safety Equipment as a Result of Backflow Through the Equipment and Floor Drain System," later became part of Unresolved Safety Issue A-17, "Systems Interaction." This issue was reviewed for the BOP study and is summarized in Section 2.3 of this report.

Auxiliary Equipment (Information Notice 83-56)

Information Notice 83-56 gives the specifics of one case where the auxiliary equipment required to support operation of the Emergency Core cooling system was too narrowly defined. This is an isolated case and has no generic conclusion applicable to the BOP study.

Service Water (Bulletin 81-03)

The increasingly wide distribution of Asiatic clams and their ability to live in freshwater piping systems, as well as the growth of mussels in saltwater systems was the topic of Bulletin 81-03. The Bulletin required licensees to look for clams and mussels and to set up ongoing programs to detect their establishment, and to eliminate them if detected.

Although this problem does have some safety significance, it is difficult to see how it could create a challenge to the safety systems. In addition, the programs required by the Bulletin should have mitigated the problem. It was concluded that this issue required no follow-up in this study.

Gas Entry into Solid Systems (Information Notice 83-77)

Entry of gas into normally solid systems has caused multiple incidents of system failures, as presented by Information Notice 83-77. Gasbound pumps in the BOP could cause safety problems, and some situations could result in chalienges to the safety systems. The Information Notice gives details on four such gas entrainment events, one of which was on a BOP system (service water). In spite of this, however, the 
root causes of these events seem scattered, with no apparent generis lesson to be addressed by the BOP project. Therefore, due to the limited number of reported events, and the variable root causes, there was no purpose in considering this issue further. Note, however, that gas (steam) binding of auxiliary feedwater pumps was dealt with elsewhere (Notice 84-06 and Bulletin 85-01).

Main and Auxiliary Feedwater System Problems (Information Notices 84-06, 8614, 86-14 Supplement 1, 87-34, and 87-53; Information Bulletins 85-01 and 85-03)

These Information Notices and Bulletins point to some repetitive problems experienced in the feedwater systems, especially in auxiliary feedwater systems. The role of these systems in the BOP-related reactor trips was addrersed in the analys is performed in this siudy.

\section{L.3 Unresolved Safety Issues and Nuclear Generic Issues}

Two Unresolved Safety Issues (USIs) and seven Nuclear Generic Issues (GIS) were identified as being related to the BOP study. These nine issues were reviewed in detail and applicable information was factored into the BOP study. The nine issues are listed below, each with a summary of how it relates to the BOP study.

USI A-17, "Systems Interactions in Nuclear Power Plants"

The class of adverse systems interactions that is the subject of USI A17 includes, as a subset, the BOP-related plant trips or safety system degradations $+:$ at are under investigation in this study. The resolution of the narrowly-defined USI A-17 is directed toward the risk implications of specific external events, i.e., earthquakes and floods. The documentation generated during the NRC/industry investigation of USI A-17 did not provide significant BOP-related insights beyond those obtained from examination of the LERs that reported on significant systems interaction events. 
USI A-47, "Safety Implications of Control Systems"

Documentation related to the investigation and resolution of USI A-47 included two NUREG reports (1217 and 1218) and four NUREG/CR reports $(3958,4385,4386$, and 4387). The resolution of USI A-47 focused almost exclusively on the adequacy of steam generator (PWR) and reactor vessel (BWR) overfill protection, with implications for reactor vessel damage, steamline break, or steam generator tube rupture events. The risk-related information in the USI A-47 documents reviewed was reviewed concerning the estimation of the effects on public risk of BOP challenges to safety systems.

\section{GI-23, "Rtactor Coolant Pump Seal Failure"}

GI-23 considered the causes and effects of reactor coolant pump. (RCP) seal failure and concluded that station biackout was the only probable event that could cause a RCP seal failure severe enough to result in leakage equivalent to a small-break loss of coolant accident. Hence, the resolution of this issue was tied to station blackout (Unresolved Safety Issue A-44).

The LER search done for the BOP study identified station blackout events, but they were not included in the BOP data base initiating event for the blackout was onsite, e.g., transformer failure.

GI-65, "Component Cooling Water System Failures"

Generic Issue 65 identified reactor coolant pump seal failure in PWRs as the primary safety concern resulting from total loss of component cooling. This issue was therefore absorbed by GI-23, "Reactor Coolant Pump Seal Failure." Consideration of GI-23 as part of this study covered all issues raised by GI -65 .

GI-93, "Steam Binding of Auxiliary Feedwater Pumps"

GI-93 raised a potentially serious BOP issue. The problem was effectively solved in 1985 by increased operator surveillance of the auxiliary feedwater line temperature and is no longer a regulatory or 
technical issue. The BOP study therefore did not consider GI-93, since steam binding of the auxiliary feedwater pump should not be a future concern.

GI-122, "Miscellaneous Feedwater Issues"

GI-122 principally investigated the reliability of auxiliary feedwater systems. It was concluded that plants with a two-train auxiliary feedwater system were the most vulnerable. On a plant-by-plant basis, each of the seven two-train plants was evaluated and recommendations for changes were made and implemented.

Since the reliability of the auxiliary feedwater systems had recently been evaluated and the least reliable systems improved, the BOP study did not concentrate on the auxiliary feedwater system.

GI-130, "Essential Service Water Pump Fallures at Multi.Plant Sites"

GI-130 deals with a narrow problem which can occur only in a small population of plants. The methods and ideas employed for the investigation and resolution of this issue were found to be of little relevance to the BOP study since the conditions analyzed are probabilistic. An event of the kind considered in GI-130 has never occurred.

GI-HF-01, "Human Factors Program Plan"

The Human Factors Progran Plan provides a definition of perceived weaknesses in the human factors engineering of nuclear power plants, goals to correct those weaknesses, and outlines of how to achieve those goals. Reduction of human errors was of interest to the BOP study and was considered by evaluating trends in human-error-related trips.

GI-HF-02, "Maintenance and Surveillance Program Plan"

Investigations for the Maintenance and Surveillance Program Plan served as a source for the maintenance policy and the proposed rule on maintenance program effectiveness. Since the area of maintenance, as 
it applies to the BOP, is believed to be an important part of the problem of BOP challenges to safety systems, these efforts toward improving maintenance may be part of the overall solution to the problem at which the BOP study was aimed. Hence, this Generic Issue, the documerits prepared for $i t$, and, perhaps most importantiy, the proposed rule on maintenance programs, were all considered in the study.

\section{L.4 Maintenance Rulemaking Activities}

The development of the Maintenance Rule was reviewed from its inception as the Maintenance and Surveillance Program Plan in 1985, through the proposed Rule on Maintenance (November 1988) and its subsequent deferral in May 1989.

As part of the monitoring of the maintenance rulemaking, BOp project personnel attended the NRC-sponsored workshop in November. 1988, as well as a meeting of the Advisory Committee on Reactor Safeguards (March 1989) and an NRC meeting (May 1989) on this topic. The proceedings of the workshop were publitshed as NUREG/CP-0099.

The maintenance rulemaking efforts are the result of NRC concern that inadequate maintenance on the part of some licensees is compromising safety. The ilidustry h's resisted NRC attempts at rulemaking in this area, citing industry improvements through self-regulation.

Action on the proposed rule was deferred as of May 1989 to allcw for further study and monitoring of industry progress. Initially, the proposed maintenance rule was to cover essentially all BOP systems; the final rule, as proposed by the NRC staff, was somewhat restricted in scope, but sti11 relevant in tis implications for the BOP systems. All licensees were to have a maintenance program with certain broadly stated attributes.

\section{L.5 Precursor Identification Program}

The Accident Sequence Precursor Program was examined, principally as it was presented in NUREG/CR-3591 and NUREG/CR-4674. The results of this effort are discussed in Section 5.2 of this report. 


\section{L.6 ACRS Information and Meetings}

The activities of the Advisory Committee for Reactor Safety (ACRS) and its subcommittees were monitored for BOP-related information, which was utilized in this study when it was applicable. The former ACRS subcommittee on BOP systems has been discontinued, with its functions picked up by the Subcommittee on Secondary systems. Other subcommittees monitored were:

$\begin{array}{ll}0 & \text { AC/DC Power Systems Reliability } \\ 0 & \text { Auxiliary Systems } \\ 0 & \text { Human Factors } \\ 0 & \text { Instrumeritation and Control Systems } \\ 0 & \text { Maintenance Practices and Procedures } \\ 0 & \text { Reliability Assurance } \\ 0 & \text { Systematic Assessment of Experience. }\end{array}$

\section{L.7 AEOD Activities}

Relevant activities for the Office of Analysis and Evaluation of Operational Data (AEOD) were monitored, primarily by reviewing AEOD reports. Many of the applicable reports are periodic reports (quarterly, annual, etc). Two of these, AEOD/P503 and AEOD/P504, are summarized below as examples:

AEOD/P503, "Engineered Safety Feature Actuations At Commercial United States Nuclear Power Reactors January I Through June 30, 1984"

AEOD/P503 documents an analysis of Licensee Event Reports of ESF actuations. Many of the events reported involved or were influenced by failures in BOP systems. One of the four problem areas identified from this study that is of safety significance, involving the BOP, is component cooling water system interaction.

AEOD/P504, "Trends and Patterns Report of Unplanned Reactor Trips at U.S. Light Water Reactors in 1984"

This report presented findings that were very relevant to the BOP study. It indicated that in 1984, about 59 percent of reactor trips above 15 percent power were related to BOP systems: feedwater $(27$ 
percent), turbine (15 percent), condensate ( 6 percent), main generator ( 0 percent), main steam ( 5 percent). It was also identified that 71 percent of the trips between 2 percent and 15 percent power leve 1 were associated with BOP systems: Feedwater (40 percent), turbine (18 percent), and main steam (13 percent). Most of these trips were caused by hardware faiiure in BOP systems.

\section{L.8 Efforts by Utilities and Industry Groups}

Numerous utilities and industry groups have reactor trip reduction programs, almost all of which have a BOP component. Information about these programs was evaluated for the BOP study. Four categories of programs were evaluated: utility programs, NUMARC/INPO/EPRI programs, Owners Group programs, and international programs.

\section{L.8.1 Utility Programs}

NUREG/CR-4783, "Analysis of Balarice of Plant Regulatory Issues," contains a detailed discussion and comparisor of reactor trip reduction programs or performance/reliability improveme it programs at six U.S. utilities. No additional iniormation on individual uti?ity programs was reviewed; ratier, composite information from sources such as INPO, NUMARC, and the Owrers Groups was emphasized.

\section{L.8.2 NUMAKC/INPO/EPRI}

The Nuclear Management and Resource Council (NUMARC) has established quantitative scram reduction goals for the industry. The original goal was set in 1984 and there have been yearly revisions downward since.

Establishing the methods to achieve the goals and tracking the results was left to INPO and the Owners Groups.

The Institute for Nuclear Power Operations (INPO) has defined areas for specific scram reduction efforts, as detailed in INPO-85-011, "Scram Reduction Practices," May 1985. The areas are: administrative, system/design, maintenance, surveillance testing, and operations. 
In the adminisirative area, three efforts were urged: improved communication becween plants; improved quality of root cause evaluations, and augmented sharing of ideas to reduce reactor trip frequency. In the system design/modification category, three goals were defined: identify common design problems that are reactor trip root causes, identify possible solutions to the design problems, and focus on feedwater-related trips. The maintenance goal is to initiate act ities to reduce on-line and outage maintenance errors. Reducing surveillance test errors was the stated goal in the surveillance category, and for operations, two goals were set: identify human factor root causes of trips and identify possible solutions.

The involvement of the Electric Power Research Institute (EPRI) in the effort to reduce scram frequency has been primarily the production of a series of studies of the effects on scram frequency of trip setpoint modifications. Four reports were generated:

- "Reducing Scram Frequency by Modifying Reactor Setpoints for a Westinghouse 4-Loop Plant," NSAC/94, Apri1 1986.

$0 \quad$ "Reducing Scram Frequency by Modifying Reactor Setpoints for a Westinghouse 3-Loop Plant," NSAC/99, December 1988.

- "Scram Reduction by Relaxing Setpoints, An Analys is of C-E PWR's with Digital Controls Using RETRAN-02," NSAC/93, January 1986.

$0 \quad$ "Scram Reduction by Relaxing Setpoints, An Analyses of C-E PWRs with Analog Controls Using RETRAN-02," NSAC/92, November 1985.

\section{L.8.3 Owners Group Programs}

The four nuclear steam supply system owners groups are very active in BOPrelated activities. Babcock and Wilcox (B\&W) Owners Group activities include the Safety and Performance Improvement Program (SPIP), the Trip Reduction and Transient Response Improvement Program, and the Comparative Study. Owners of B\&W plants are implementing the recommendations of these programs through $p l a n t-s p e c i f i c$ modifications aimed at reducing the frequency of reactor trips. 
The Combustion Engineering Owners Group (CEOG) consists of a steering group and several technical subcommittees. The Scram Reduction Program, initiated in May 1985, is being implemented through the Operations Subcommittee. The major thrust of this program is not in the balance of plant. The only significant BOP activity involves an open interchange of information between the member CE utilities at meetings in which BOP-related trips, root causes, and experience with corrective actions are disciussed. The consensus among CE utilities is that the major contributor to BOP trips is feedwater system malfunction, caused by either equipment failure or human error. Florida Power and Light has installed the Combustion Engineering digital feedwater control system at $S t$. Lucie and has reported excellent results in terms of low power feedwater control, which is one problem area causing frequent trips. Southern California Ecison is looking into reducing the steam generator low-level trip setpoint by advanced analyses, anticipating that a setpoint reduction would help reduce feedwater-associated trips. Combustion Engineering is preparing specific proposals to the CEOG regarding reduction in the frequency of trips, which will include consideration of BOP systems and components.

The General Electric Boiling Water Reactor Owners Group. (BWROG) is conducting a Scram Frequency Reduction Program (SFRP), which is subdivided into three areas - - operations, systems design, and maintenance. The operations group is establishing a data base on both automatic and manual reactor trips, with root cause information, and is examining the question of how best to perform effective root cause evaluations. The systems design group is responsible for maintaining the reactor trip data base, for suggesting improvements in root cause evaluations and related training, and for trend analysis of the data base. The maintenance group is examining maintenance-related contributions to reactor trips. Plans for the SFRP include identification of the most critical BOP components in terms of trips and investigating why some BWRs are more resistant to trips than others, given the same BOP component failure.

The Westinghouse Owners Group is conducting a Trip Reduction and Assessment Program (TRAP). Based on operating experience, the initial emphas is is being placed on the feedwater control system configurations at low powe and on the steam generator low-level trip setpoints. Analyses indicated that a steam generator level trip modification that included sensor inputs for 
containment temperature and pressure could allow up to a 15 percent widening of the level trip band. Feedwater and steam generator level trip modifications have been made on several Westinghouse plants. The TR.AP also includes examination of turbine-generator and control systems, electrical systems, maintenance issues, and detailed categorization of the root causes of trips.

\section{L.8.4 International Programs}

The Nuclear Energy Agency of the Organization for Economic Cooperation and Development (NEA/OECD) conducted a symposium on scram reduction in Tokyo, Japan, in April 1986. The proceedings of this symposium, "Reducing the Frequency of Nuclear Reactor Scrams," were reviewed for the BOP study. Ten countries participated: Belgium, Canada, France, West Germany, Great Buttain, Italy, Japan, Spain, Sweden, and the United States. All of the types of commercili nuclear power plants found among the OECD nations were represented. Each country offered its experience, analysis, and philosophy on scrams and scram reduction, including detailed scram statistics. Other papers were given which outlined the process of scram cause identification and correction, including the resulting design improvements. The Germans made a presentation on their instrumentation and control system which helps keep the German scram rate to around one per reactor year. The Japanese described improvements they have made to keep their scram rate to a similar low number, which was approximately one-fifth of the scram rate of the U.S. in 1985. Automatic testing devices, scram setpoint changes, operator and maintenance training, preventive maintenance, and improvements in design and construction were all discussed as methods to reduce scram frequency. 


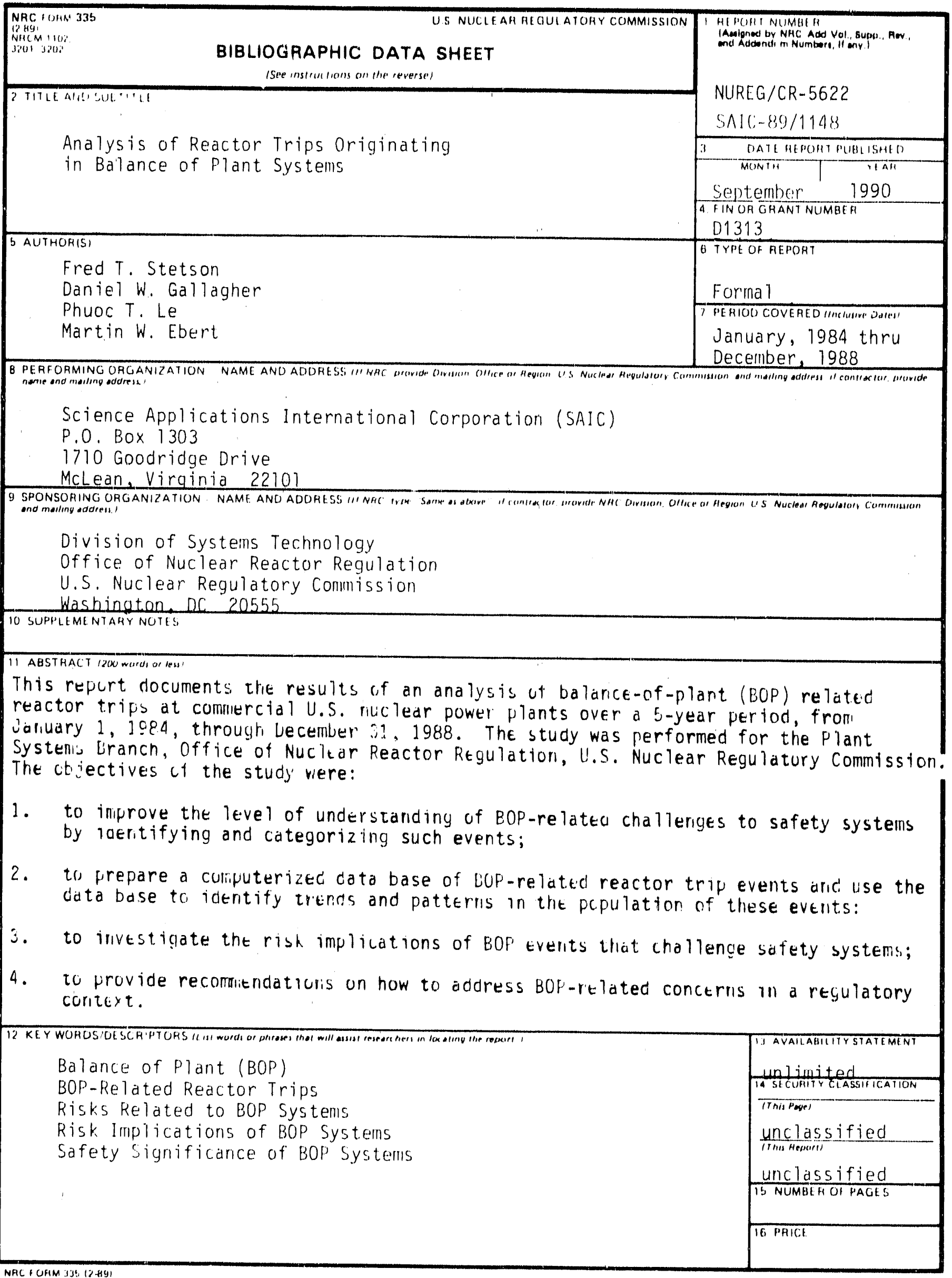



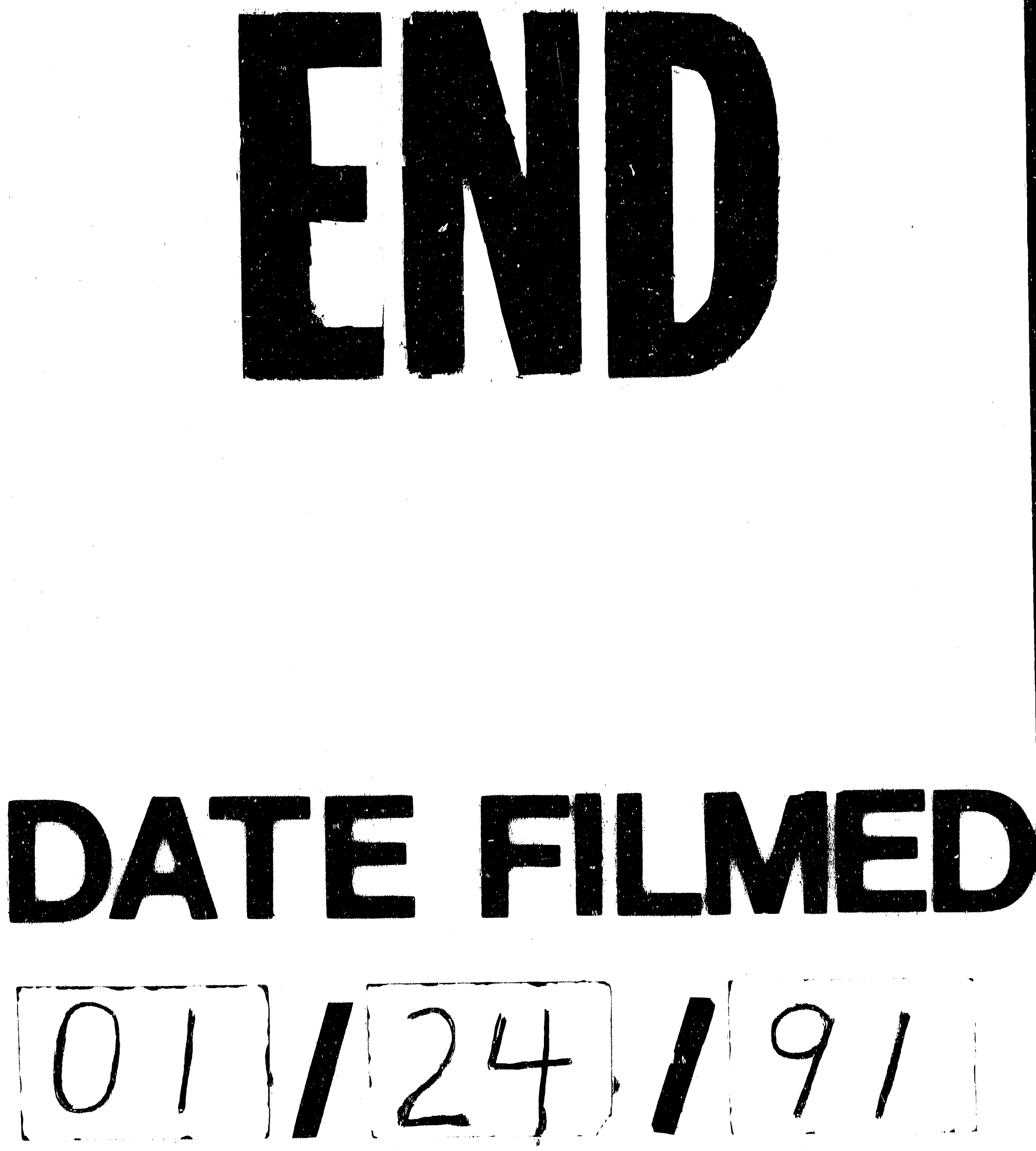
